University of Miami Law School

University of Miami School of Law Institutional Repository

Articles

Faculty and Deans

2002

Enron and the Dark Side of Shareholder Value

William Wilson Bratton

Follow this and additional works at: https://repository.law.miami.edu/fac_articles

Part of the Law Commons 


\title{
Enron and the Dark Side of Shareholder Value
}

\author{
William W. Bratton
}

This Article addresses the implications that the Enron collapse holds out for the selfregulatory system of corporate governance. The case shows that the incentive structure that motivates actors in the system generates much less powerful checks against abuse than many observers have believed. Even as academics have proclaimed rising governance standards, some standards have declined, particularly those addressed to the numerology of shareholder value. The Articles inquiry begins with Enron's business plan. The Article asserts that there may be more to Enron's "virtual firm" strategy than meets the eye beholding a firm in collapse. The Article restates the strategy as an application of the incomplete contracts theory of the firm that prevails in microeconomics today and asserts that Enron failed because its pursuit of immediate shareholder value caused it to misapply the economics, mistaking its own inflated stock market capitalization for fundamental value. The Article proceeds to Enron's collapse, telling four causation stories. This ex ante description draws on information available to the actors who forced Enron into bankruptcy in December 2001. The discussion accounts for the behavior of Enron $s$ principals by reference to the shareholder value norm and Enron's corporate culture. Finally, the Article takes up the self-regulatory system of corporate governance, asserting that the case justifies no fundamental reform. The costs of any significant new regulation can outweigh the compliance yield, particularly in a system committed to open a wide field for entrepreneurial risk taking. If we seek high retums, we must discount for the risk that rationality and reputation will sometimes prove inadequate as constraints. At the same time, we should hold critical gatekeepers, particularly auditors, to high professional standards. The Article argues that present reform discussions respecting the audit function do not adequately confront the problem of capture demonstrated in this case.

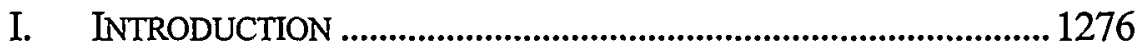

II. ENRON AND THE CONTRACTARIAN IDEAL................................ 1288

A. The Virtual Corporation............................................... 1288

$B$. Enron's Virtual Corporation and the Theory of the

Firm...................................................................................... 1294

III. ACCOUNTING FOR ENRON'S COLLAPSE-FOUR STORIES ........... 1299

A. Enron as Conventional Market Reversal......................... 1299

B. Enron as Derivative Speculation Gone Wrong.............. 1302

C. Enron as a Den of Thieves........................................... 1305

* Samuel Tyler Research Professor of Law, The George Washington University Law School; Visiting Professor of Law, Georgetown University Law Center (Spring 2002). My thanks to Matt Barrett, Margaret Blair, Jill Fisch, Miriam Galston, Mitu Gulati, Shi Ling Hsu, Lyman Johnson, Kim Krawiec, Don Langevoort, David Millon, Larry Mitchell, Ron Pearlman, Richard Pierce, Warren Schwartz, Bill Vukowich, Andrew White, and participants of workshops at the Georgetown, George Washington, and North Carolina Law Schools for assisting in this project with comments and materials. This Article speaks as of April 11, 2002. 
1. Accounting Rules and Chewco's Phantom

Equity Investor.

2. Fastow's $\$ 30$ Million ............................................. 1309

3. SPEs and Overstated Numbers............................... 1314

D. Enron as a Bank Run................................................. 1320

E. Summary and Analysis .............................................1326

IV. ENRON AND CORPORATE SELF-REGULATION ........................... 1332

A. Enron and the Monitoring Model of Corporate

Governance..................................................................... 1333

B. Enron, Generally Accepted Accounting Principles,

and Auditor Independence ............................................... 1340

1. The Violations...................................................... 1342

2. Incentive Incompatibility at Arthur Andersen........ 1348

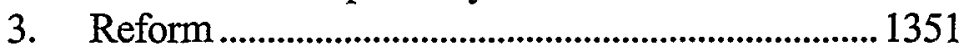

4. Audits and Shareholder Value Maximization ........ 1357

V. CONCLUSION-ENRONAND THE WAY WE LIVE NOW............... 1358

\section{INTRODUCTION}

Each economic expansion brings forth an investment so good that people treat it as having broken the iron law of risk and return-the economic teaching that those who want big returns have to take big risks. In the $1920 \mathrm{~s}$, the investment was common stocks bought on margin. In the 1960s, it was Nifty Fifty growth stocks. In the 1970s, it was commodities whose prices were going to rise forever. In the 1980s, it was the junk bond, a miracle of financial science that offered a super-normal return without a greater risk of default. In the late 1990 s, it was new-economy stocks that levitated on heroic productivity stories and predictions of a 36,000 Dow. And then came Enron.

Enron flew high. When its stock price peaked at close to ninety dollars in August 2000, it was America's seventh largest firm by market capitalization. ' In one category it even had the number one slot-Fortune Magazine hailed it as America's most innovative firm for five years running. ${ }^{2}$ Enron also came in number one when it fell. It went into Chapter 11 on December 2, 2001, as the largest bankruptcy reorganization in American history. ${ }^{3}$ Meanwhile, its stock

1. The price/earnings ratio was sixty, however.

2. Pratap Chatterjee, Enron: Pulling the Plug on the Global Power Broker, CoRPWATCH, at 6, available athttp://www.corpwatch.org/issues/PRT.jsp?articleid=1016 (Dec. 13, 2001).

3. Wendy Zellner et al., The Fall of Enron, BUS. WK., Dec. 17, 2001, at 30, 33. 
had fallen to around sixty cents a share, ${ }^{4}$ victim to two more Enron superlatives-history's biggest financial fraud and its biggest audit failure.

At first the nation's financial system took the crack up in stride, adjusting the share prices of Enron's biggest lenders a notch downwards. Growing worries about other firms' financial reports finally caused a major market correction two months later. ${ }^{5}$ The residuum of insecurity will continue to raise risk premiums and depress stock prices. ${ }^{6}$ But the most visible victims are Enron's stockholders and employees, especially the employees who were shareholders. Even as 4000 were laid off around the time of the bankruptcy filing, all faced the grim realization that in the company's final weeks management had locked down their 401(k) plan, which had been sixty-percent invested in Enron stock. ${ }^{7}$

Corporate failures as big and fast as this one tend to be held out as examples for future business regulation. Enron's failure is no exception, implicating a long list of regulatory topics well before completion of formal investigations into the company's management and the collapse's cause. On its face Enron raises issues for the future of energy deregulation, the mandatory disclosure system under the securities laws, ${ }^{3}$ the regulation of the accounting profession, and

4. Peter Coy et al., Enron: Running on Empty, Bus. WK., Dec. 10, 2001, at 80, 80.

5. Gretchen Morgenson, Worries of More Enrons to Come Give Stock Prices a Pounding, N.Y. TMIES, Jan. 30, 2002, at C1.

6. Steve Liesman, The Outlook: Enron Fallout May Cut Stock Prices in General, WaLL ST. J., Jan. 21,2002, at A1. The insecurity also has caused a marked contraction of the commercial paper market, which, in turn, will cause borrowing costs to rise significantly at corporations losing access to this inexpensive source of credit. Gregory Zuckerman, Cash Drought: A Dwindling Supply of Short-Term Credit Plagues Corporations, WALL ST. J., Mar. 28,2002 , at A1.

7. $401(\mathrm{k})$ plans are not subject to ERISA's constraints on investments by defined benefit pension plans, which are subject to a ten percent cap on investment in the employer firm's stock. Enron is by no means the only company whose employees' 401(k) plans are heavily invested in their own stock. Each of the plans of Coca-Cola, Anheuser-Busch, Dell Computer, Abbott Laboratories, and Proctor \& Gamble was invested with more than eighty percent in company stock as of December 2001. Ellen E. Schultz, Employers Fight Limits on Firms Stock in $401(\mathrm{k}) \mathrm{s}$, WALL ST. J., Dec. 21, 2001, at C1.

For an excellent discussion of the implications of the $401(\mathrm{k})$ diversification question, see David Millon, Enron and the Dark Side of Worker Ownership (working paper) (on file with author).

8. The fact that Enron made special disclosures about investments in Special Purpose Entities (SPE) to investors in the entities has created a stir on the ground that SPE investors should not have more information than other investors in the marketplace. See Diana B. Henriques \& Kurt Eichenwald, A Fog Over Enron, and the Legal Landscape, N.Y. TIMES, Jan. 27, 2002, at MB1. Why this should be is a puzzle, at least apart from the recently promulgated Regulation FD. Under the materiality convention of Generally Accepted 
internal corporate governance systems. ${ }^{9}$ For employee pensions, the wheels of action started to turn even before the end of 2001 as bills were introduced in the House and Senate to limit the amount of company securities in $401(\mathrm{k})$ retirement plans to ten or twenty percent. $^{10}$ Legislation has since been presented covering a range of subjects. ${ }^{11}$

The claims of regulatory failure have a sharp edge due to Enron's profile as one of corporate America's most aggressive political players. Deregulatory politics lay at the core of the company's business plan. Its primary business, energy trading, only came into existence in the wake of deregulation of electricity and natural gas production and supply. Led by its founding chief executive officer (CEO), Kenneth L. Lay, Enron went from state to state to prod local regulators to mandate the unbundling of vertically integrated utilities. ${ }^{12}$ It succeeded in twenty-four states, ${ }^{13}$ clearing a field for the creation of new markets it could exploit. These political successes earned Enron admiration in

Accounting Principles (GAAP), see DAVID R. HerivtTZ \& MATTHEW J. BarretT, ACCOUNTING FOR LAWYERS 71 (3d ed. 2001), financial statements do not report all details respecting a business for fear of incoherent results. Meanwhile, to induce a private investor to join in a particular project is to provide detailed information about that project, subject to a confidentiality agreement. Such an inequality of information is a necessary result when reporting companies do project finance, joint ventures, and private placements.

9. Even the repeal of the Glass-Steagall Act has come in for questioning on the ground that the losses of Citibank and the Morgan Bank might have been lower had they not been providing Enron with investment banking services. Jeanne Cummings et al., Enron Lessons: Firms Need to Have Assets, and Auditors Oversight, WALL ST. J., Jan. 15, 2002, at A1.

10. Schultz, supra note 7, at C1.

11. See, e.g., S. 2003, 107th Cong. (2002) (providing for a variety of reforms respecting financial accounting); Auditor Independence Act of 2002, S. 1896, 107th Cong. (2002) (prohibiting auditors from providing management services); Independent Investment Advisers Act of 2002, S. 1895, 107th Cong. (2002) (requiring investment advisors to disclose ties with companies being analyzed by them); Fully Informed Investor Act of 2002, S. 1897, 107th Cong. (2002) (requiring disclosure of the sale of securities by an officer to be made available quickly to the Securities and Exchange Commission (SEC)). In addition, SEC Chairman Harvey Pitt, responding to an immediate need to restore confidence in the audit process, has proposed a new internal disciplinary structure for the accounting profession. See, e.g., Michael Schroeder, SEC Proposes Accounting Disciplinary Body, WALL ST. J., Jan. 17,2002 , at $\mathrm{Cl}$.

12. Holman W. Jenkins, Jr., Editorial, Enron = Deregulation?, WALL ST. J., Dec. 19, 2001, at A19. Enron started out as a natural gas pipeline at a time when oil was lower-priced. Its natural gas business began to flourish after the Federal Energy Regulatory Commission (FERC) changed its rules in 1985 to permit utilities to shop for gas and pipelines and to search for customers. Wendy Zellner et al., Enron's Power Play, Bus. WK. ONLINE, at http://www.businessweek.com/2001/01_07/b3719001.htm (Feb. 12, 2001).

13. Leslie Wayne, Enron, Preaching Deregulation, Worked the Statehouse Circuit, N.Y. TIMES, Feb. 9, 2002, at B1. 
business circles as a center of innovation and entrepreneurship. ${ }^{14}$ Jeffrey Skilling, who succeeded Lay as Enron's CEO in February 2001 (to resign the following August as storm clouds gathered), described a firm with a mission against entrenched monopoly and its paid protectors in government. Enron was "on the side of the angels":

In every business we've been in, we're the good guys. That's why they don't like us. Customers love us, but the incumbents don't like us. We're bringing the benefits of choice and free markets to the world. You have no idea how frustrating it was in the early days of gas. They had built all the rules to protect their monopolies. ${ }^{15}$

But even as Enron fought and won battles against protected energy monopolies, it succeeded to and surpassed their influence activities. ${ }^{16}$

Enron spent copiously on politics. For example, the $\$ 2.4$ million of political contributions it paid in 2000 exceeded by $100 \%$ those of the next-most-generous energy company. ${ }^{17}$ In 2000 , Enron also paid $\$ 2.1$ million to a dozen or so Washington lobbying firms. ${ }^{18}$ Enron obtained good results from such investments, notably in connection with the passage in 2000 of the Commodity Futures Modernization

14. Zellner et al., supra note 3 , at 30.

15. OnLine Extra: $Q \& A$ with Enron's Skilling, Bus. WK. ONLINE, at http://www.businessweek.com/2001/01_07/b3719010.htm (Feb. 12, 2001).

16. Enron's state-level political activities were not in a strict sense ever directed to securing deregulation of energy production and distribution. For Enron, deregulation meant special legislative protection for its own business model. It encouraged the states to mandate their utilities' unbundling along lines suited to Enron's lines of business, leaving open no playing field for the operation of competing business models. See Jenkins, supra note 12, at A19.

Enron at first joined the Harvard Electricity Policy Group, a forum organized by academics in 1991. In 1994, it withdrew its support from the group due to disagreements about the shape restructurings should take. Letter from Professor Richard Pierce (Feb. 12, 2002) (on file with author).

It also is noted that Enron's operations abroad have earned the opprobrium of human rights activists, in particular with respect to its $\$ 3$ billion joint venture with the state utility of Maharashtra in India. Human Rights Watch and Amnesty International have documented human rights abuses on the part of local police officers acting as a private security force for Enron. They accuse Enron's cops of beating local opponents of the power plant and of dragging citizens out of their homes and then beating them for refusing to cooperate with the firm. Chatterjee, supra note $2, \uparrow 33$.

17. Enron spent $\$ 10.2$ million on influence in Washington between 1997 and 2000 . During his political career, George W. Bush has received \$774,100 from Enron itself and Enron's management, $\$ 312,500$ of which he received during his gubernatorial campaign. Chatterjee, supra note 2.

18. Robert Kuttner, Editorial, The Lesson of Enron: Regulation Isn't A Dirty Word, Bus. WK., Dec. 24, 2001, at 24. One of these representatives was Marc Racicot, now the Republicans' national chairman. 
Act. ${ }^{19}$ Senator Phil Gramm, spouse of Wendy Gramm, one of Enron's outside directors and a member of its audit committee, ${ }^{20}$ assured that the legislation included the "Enron Point," a complete exclusion for energy trading companies from financial or disclosure requirements respecting portfolios of over-the-counter derivative securities. Enron thereby achieved something available to no other leading dealer in derivative contracts-complete exemption of its activities from federal supervision and oversight. ${ }^{21}$

Yet none of Enron's political friends came forward when it approached the Treasury for a bailout in late 2001. Washington Republicans kept the firm at a conspicuous distance..$^{22}$ Even so, Enron associations now soil politicians on a per se basis. ${ }^{23}$ Any sign of past proximity to the firm drives the press into a frenzy. The same goes for the business community, where scrutiny extends to the conduct of its largest lenders, J.P. Morgan Chase \& Co. and Citigroup, Inc. ${ }^{24}$ Remarkable extremes have been reached by a press eager for scandal:

19. Commodity Futures Modernization Act of 2000, Pub. L. No. 106-554, 114 Stat. 2763 (2000).

20. She is alleged to have received between $\$ 915,000$ and $\$ 1.85$ million in compensation from Enron between 1993 and 2001. Bob Herbert, Editorial, Enron and the Gramms, N.Y. TMES, Jan. 17, 2002, at A29. How much of the deferred portion of this she now gets to collect remains in question.

21. Makers of comparable products are either banks, broker-dealers, commodities dealers, or exchanges or their members, and thereby subject to regulation under one or another federal regime.

22. See, e.g., Cummings et al., supra note 9, at A1; Michael Schroeder, Enron Debacle Will Test Leadership of SEC's New Chief, WALL ST. J., Dec. 31, 2001, at A10 (discussing comments of President George W. Bush on Enron).

23. For an analysis along these lines, see Albert R. Hunt, Editorial, $A$ Scandal Centerpiece: Enron's Political Connections, Wall St. J., Jan. 17, 2002, at A15.

Vice President Cheney takes the worst of this by virtue of his energy policy portfolio. Unfortunately for Cheney, his contacts were not limited to policy discussion. At Lay's request, he met with Indian officials in June 2001 to pressure them for concessions in respect of an ongoing political battle between Enron and the Maharashtra state utility. Richard A. Oppel, Jr., Despite Warning, Enron Chief Urged Buying of Shares, N.Y. TIMES, Jan. 19, 2002, at A1.

24. The SEC is investigating Morgan for delaying full disclosure of its Enron losses. These first were said to be $\$ 900$ million, a figure later raised to $\$ 2.6$ billion because guarantors of Morgan's position have refused to pay. The matter is in litigation. Jathon Sapsford \& Anita Raghavan, Trading Charges: Lawsuit Spotlights J.P. Morgan's Ties to the Enron Debacle, WALL Sr. J., Jan. 25, 2002, at A1; Anita Raghavan et al., SEC Examines Ties Between Banks and Enron, WALL ST. J., Jan. 15, 2002, at C1. Citigroup seems to have engineered a preference for itself-a $\$ 250$ million bootstrap from unsecured to secured status for itself in respect of the last rounds of prebankruptcy lending. Jathon Sapsford \& Mitchell Pacelle, Citigroup's Enron Financing Stirs Controversy, WaLL ST. J., Jan. 16, 2002, at C1. 
You get your name in the paper simply by virtue of being a purchaser of a private placement note of an Enron equity affiliate. ${ }^{25}$

As with the political community, Enron failed to find significant sources of support in the business community as it struggled to stay solvent. Many saw it as an arrogant, uncooperative player. ${ }^{26}$ It had insisted on, and succeeded in, getting its own way with business counterparties as well as government regulators. ${ }^{27}$ Its famously opaque financial statements showed that Enron found it neither necessary nor desirable to share a clear picture of its operations and finances with either its own shareholders or the wider financial community. This was a firm whose CEO, Skilling, publicly castigated as an "asshole" an analyst who had the temerity to ask a critical question about Enron's financial reports. ${ }^{28}$ When financial journalist, Bethany McLean, asked early questions about the company, in Is Enron Overpriced?," Skilling accused her of being unethical for publishing an underresearched piece. ${ }^{30}$

Two schools of thought show up prominently in discussions of the meaning of Enron's collapse. On one side stand supporters of deregulation, many of whom once touted Enron and now find it more than a little embarrassing. Its collapse, they tell us, should be taken as an exemplar of free market success. ${ }^{31}$ If Enron was a house of cards, it was free market actors who blew it down, with a free market administration keeping its hands off. Any violations of law will be brought to light through investigations by the Congress, the Securities and Exchange Commission (SEC), and the Justice Department, along with fact finding connected with a raft of pending lawsuits.

25. Gretchen Morgenson, Many May Be Surprised to Be Enron Investors, N.Y. TMES, Jan. 25, 2002, at Cl.

26. See Zellner et al., supra note 3 , at 34 .

27. Enron used its clout as a source of fees to bully actors in the financial community to participate in increasingly dubious off-balance sheet financings. Wendy Zellner et al., The Man Behind the Deal Machine, Bus. WK., Feb. 4, 2002, at 40, 40-41.

28. Special Report-Enron: The Amazing Disintegrating Firm, ECONOMST, Dec. 8 , 2001, at 61 [hereinafter Special Report]. The incident occurred in April 2001. Heather Timmons, When Execs Protest Too Much, Bus. WK., Jan. 14, 2002, at 8, 8.

29. Bethany McLean, Is Enron Overpriced?, FORTuNE, Mar. 5, 2001, at 123

30. Felicity Barringer, 10 Months Ago, Questions on Enron Came and Went with Little Notice, N.Y. TMIES, Jan. 28, 2002, at A11.

31. For a bizarre example of this thinking, see John Rossant, Editorial, Why a Few Enrons Would Do Europe Goad, Bus. WK., Dec. 31, 2001, at 58, 58 (asserting that Enron shows that government support for industry is a bad thing). 
Meanwhile, the histories of rogues and outliers like Enron never provide a sound basis for new regulatory initiatives. ${ }^{32}$

On the opposite side stand those, including this Article's author, predisposed to draw regulatory inferences from business disasters. Enron, with its reputation as America's corporate shock troop for radical reliance on market discipline and concomitant dismantling of the New Deal regulatory legacy, ${ }^{33}$ provides an especially attractive basis for argument. These assertions encompass power supply, the deregulation of which, according to one recent commentator, "guaranteed that sharks such as Enron would emerge to cream profits by manipulating supply."34 They encompass campaign finance reform, in the eyes of many a necessary prerequisite to any other law reform triggered by Enron. ${ }^{35}$ And they encompass business law, in particular corporate and securities law's system of self-regulatory corporate governance.

This Article addresses the self-regulatory regime of corporate governance, to which Enron comes as a considerable shock. In the 1990 s, corporate self-regulation had been widely thought to have reached a high plateau of evolutionary success due to proliferating good practices and sophisticated institutional monitoring. Yet the failure in this case stemmed not from business reversal, which often cannot be avoided, but from legerdemain, which usually can be controlled. The breaking stories defied explanation $-\$ 30$ million of self-dealing by the chief financial officer, $\$ 700$ million of net earnings going up in smoke, $\$ 1.2$ billion of shareholders' equity disappearing as if by erasure of a blackboard, more than $\$ 4$ billion in hidden liabilities-and all in a company theretofore viewed as an exemplar. How could this happen in a corporate governance and disclosure system held out as the envy of the world? Either deeply concealed skullduggery or some hidden regulatory defect requiring legislative correction must have been at work.

As the scandal deepens and the criminal justice system comes to bear, the concealed skullduggery characterization becomes more

32. For this point of view, see Editorial, Investigating Enron, WALL ST. J., Nov. 30, 2001, at A14; Jenkins, supra note 12.

33. Paul Krugman, Editorial, Laissez Not Fair, N.Y. TIMES, Dec. 11, 2001, at A27.

34. Kuttner, supra note 18, at 24. Many accuse Enron of manipulation and profiteering in connection with California's power shortage of 2000 and 2001. See, e.g., Richard A. Oppel, Jr., Signs Enron Bet on Price Increase Before California Power Shortage, N.Y. TMES, Apr. 11, 2002, at C1.

35. See Stephen Labaton, Auditing Firms Exercise Power in Washington, N.Y. IMES, Jan. 19, 2002, at A1 (quoting Professor James Cox). 
prominent. The principals emerge as rogues, to be roughly expelled by the respectable business community. There lies much truth in the characterization. But the rogue characterization serves a double function-it deflects attention from the respectable community's own business practices.

This Article aspires to counterbalance with a picture of Enron's collapse that deemphasizes the rogue to focus on the regular. It reviews the particulars of the case, emphasizing the points of continuity between Enron and respectable firms. It asserts that Enron in collapse was wrought into the fabric of our corporate governance system every bit as much as Jack Welch's General Electric (GE) was in success. Like GE under Jack Welch, Enron under Ken Lay and Jeff Skilling pursued maximum shareholder value. Like GE's managers, Enron's pursued a plausible and innovative business plan. The firm collapsed for the most mundane of reasons-its managers suffered the behavioral biases of successful entrepreneurs. They overemphasized the upside and lacked patience. They pursued heroic short-term growth numbers that their business plan could not deliver. That pursuit of immediate shareholder value caused them to become risk-prone, engaging in levered speculation, earnings manipulation, and concealment of critical information.

They were rogues to be sure, but the self-regulatory system nevertheless is deeply implicated in their company's failure. Enron's collapse reminds us that our corporate governance system takes some significant risks in the name of encouraging innovation and entrepreneurship and economizing on enforcement costs. Enron's principals abused the system in plain view, taking advantage of the considerable slack it extends to successful actors. Although they did not disclose everything, they disclosed more than enough to put the system's layers of monitors on notice that their earnings numbers were soft and their liabilities understated. Similarly aggressive accounting and soft numbers are commonplace in business today. They have become wrought into the practice of shareholder value maximization.

The theory of shareholder value maximization tells a different story, of course. Academics define shareholder value by reference to management practices that enhance productivity-corporate unbundling and concentration on core competencies, the return of free cash flow to shareholders, compensation schemes that align incentives, and prompt restructuring of dysfunctional operations. But in the transfer from theory to practice, the set of economic instructions diffuses into a norm. The norm is informed by the demands of 
shareholders themselves in addition to the official economics. As the norm becomes more capacious it takes on a dark side, a negative aspect quite apart from the pain it inflicts on millions of employees for whom the cost-cutting entailed in restructuring means termination. For equity investors in recent years, the practice of shareholder value maximization has not meant patient investment. Instead, it has meant obsession with short-term performance numbers. For managers, the shareholder value norm accordingly has come to mean more than astute investment and disinvestment. It also means aggressive management of reported figures responsive to the investment community's demands for immediate value. Enron stated its adherence to the norm in its Annual Report for 2000-it was a company "laser-focused on earnings per share."

Enron forces us to confront a discomfiting fact: even as academics have proclaimed rising governance standards, some standards have declined, particularly those addressed to the numerology of shareholder value. The decline has not been limited to companies subject to enforcement actions, like Cendant ${ }^{37}$ and Sunbeam. ${ }^{3 s}$ Investigations and criticisms touch reputable names like Xerox, ${ }^{39}$ Lucent, $^{40}$ Qualcom, ${ }^{41}$ American International, ${ }^{42}$ Coca-Cola, $\mathrm{IBM}^{44}$ and GE itself. ${ }^{45}$ The number of accounting restatements, cases in which companies lower previously reported earnings, averaged 49

36. ENRON, 2000 ANNUAL REPORT 2 (2001).

37. See In re Cendant Corp. Sec. Litig., 109 F. Supp. 2 d 235 (D.N.J. 2000), aff'd, 264 F.3d 201 (3d Cir. 2001).

38. Chad Terhune \& Joann S. Lublin, Unlike Others, Dollar General Issues a Mea Culpa, Wall St. J., Jan. 17, 2002, at B1 (noting Dollar General's public apology for its accounting irregularities in the same week that "Chainsaw" Al Dunlop paid a \$15 million settlement stemming from Sunbeam's fraudulent financials).

39. Claudia H. Deutsch \& Reed Abelson, Xerox Facing New Pressures Over Auditing, N.Y. TImEs, Feb. 9, 2001, at C1.

40. Simon Romero, Lucent's Books Said to Draw the Attention of the S.E.C., N.Y. TIMES, Feb. 10, 2001, at $\mathrm{Cl}$. at 54 .

41. John A. Byrne \& Ben Elgin, Cisco: Behind the Hype, Bus. WK., Jan. 21, 2002,

42. Christopher Oster \& Ken Brown, AIG: A Complex Industry, A Very Complex Company, WALL ST. J., Jan. 23, 2002, at C16.

43. Betsy McKay, Coca-Cola: Real Thing Can Be Hard to Measure, Wall ST. J., Jan. 23, 2002, at C16.

44. William M. Bulkeley, IBM: 'Other Income' Can Mean Other Opinion, WaLl ST. J., Jan. 23, 2002, at C1; Steve Liesman, Deciphering the Black Box, WALL ST. J., Jan. 23, 2002 , at $\mathrm{C}$. The Journal holds these companies out as exemplars of what is called "black box" accounting. It's a black box when you can't figure it out.

45. Jeremy Kahn, Accounting in Wonderland: Jeremy Kahn Goes Down the Rabbit Hole with GE's Books, FORTUNE, Mar. 19, 2001, at 134; Rachel Emma Silverman \& Ken Brown, GE: Some Seek More Light of the Finances, WALL ST. J., Jan. 23, 2002, at C1. 
per year from 1990 to 1997 . By 2000 , the annual number was up to $156 .^{46}$ Clearly, the line between appropriate and inappropriate behavior has dissolved for many under real-world pressure to produce shareholder value. Exploitation and expansion of the gray area has become routine. The resulting loss of perspective facilitated Enron's step across the line to fraud. Special regulatory attention accordingly devolves on its auditor, the actor in the self-regulatory system whose primary function is to deter fraud.

This Article's inquiry into Enron's implications for corporate selfregulation (and the legal theory that supports it) begins, in Part $\amalg$, with Enron's business plan. When Enron rode high, it aspired to embody and realize the ideal of a contractual firm rooted in the touchstone economics of Michael Jensen and the late William H. Meckling. ${ }^{47}$ Enron would transform itself into a "virtual" corporation, a center for market making and hedging by high-tech experts, rather than an assetheavy energy producer. Thus viewing itself as a real time nexus of contracts, Enron looked out at the field of traditional large, vertically integrated, asset-based companies and saw a great arbitrage opportunity. Those lumbering behemoths with low returns on assets were just waiting to be dismantled, their coordinative functions to be replaced by Enron's proprietary trading markets. The strategy was lionized in the business press in early 2001 as Skilling ascended Enron's throne. By the year's end it was derided. Paul Krugman has called it "death by guru"-little more than a "perfect PowerPoint presentation." It was so trendy that "few analysts were willing to fly in the face of fashion by questioning Enron's numbers."

Certainly, few asked any questions. ${ }^{50}$ But there may be more to Enron's strategy than meets the eye beholding a firm in collapse. Part II argues that the strategy may be restated as an application of the

46. Liesman, supra note 44 , at $\mathrm{C1}$.

47. Michael C. Jensen \& William H. Meckling, Theory of the Firm: Managerial Behavior, Agency Costs and Ownership Structure, 3 J. FIN. ECoN. 305 (1976). It is noted that Jensen has taken the occasion of Enron's collapse publicly to castigate managers who seek to maximize stock prices through legerdemain rather than enhancement of fundamental value. Joseph Fuller \& Michael C. Jensen, Editorial, Dare to Keep Your Stock Price Low, WALL ST. J., Dec. 31, 2001, at AS. The authors have expanded their op-ed piece into a short paper. See Joseph Fuller \& Michael C. Jensen, Just Say No to Wall Street, available at http://www.papers.ssrn.com/abstract=297156 (Feb. 17, 2001).

48. Paul Krugman, Editorial, Death By Guru, N.Y. TIMES, Dec. 18, 2001, at A23.

49. Id.

50. One that did was Veba, a German firm which walked away from a proposed merger with Enron in 1999 after Price Waterhouse took a close look at Enron's books. Edmund L. Andrews et al., '99 Deal Failed After Scrutiny of Enron Books, N.Y. TMEs, Jan. 27,2002 , at 1 . 
incomplete contracts theory of the firm that prevails in microeconomics today. Enron failed because its pursuit of immediate shareholder value caused it to misapply the economics. It asked for too much from the strategy in terms of immediate increases in earnings per share, mistaking its own inflated stock market capitalization for fundamental value. Meanwhile, the arbitrage play it proposed remains to be made against the prevailing pattern of vertical industrial organization, only by a more level-headed management team. The virtual corporation and the regulatory and social challenges it presents remain on table.

Part III moves on to Enron's collapse, telling four causation stories. This ex ante account draws on information available to the actors who forced Enron into bankruptcy in December 2001, avoiding inquiry into the culpability of Enron's principals. The first story looks at Enron at the beginning of 2001 to show a company with some profound but very conventional problems in need of solution. This account provides a backdrop for the stories that follow. The second story depicts Enron as Long-Term Capital Management-a derivative play gone bad. The problem with this very good story is that even as the allegations pile up there remains little evidence to support it. The third story depicts Enron as a den of thieves. Here we encounter the famous $\$ 30$ million fee collected by Enron's chief financial officer, Andrew Fastow, along with shenanigans with Special Purpose Entities. The discussion asserts that there was no prima facie breach of fiduciary duty bound up in the Fastow deal at the time the Enron board approved it. At the same time, to look at Fastow and the SPE transactions is finally to encounter fraud, as Enron does shady deals with its CFO's limited partnership to conceal losses and generate earnings. Public disclosure of these activities triggers a reputational crisis for Enron but no negative financial results large enough to bring it down. We get those with the fourth story-the revelation of $\$ 4$ billion of hidden contingent liabilities. This triggers a credit rating downgrade, a liquidity crisis, and a ticket to Chapter 11.

Part III accounts for these actors' behavior by reference to the shareholder value norm and Enron's corporate culture. More particularly, the two stories, Part II's story of Enron in success and Part III's story of Enron in collapse, combine to imply that the principals saw themselves as players in a tournament. Their job was not just to make money, but to make the most money-to be the superstar firm. For a superstar firm, success did not mean merely doing better than the next firm. It meant destroying the next firm and much of industrial 
organization along with it and always delivering good numbers. This single-minded pursuit of first-place competitive victory caused Enron's managers to destroy their firm.

Part IV turns to corporate self-regulation for a conventional, but sobering account of responsibility. To help maintain focus, attention is limited to Enron's officers, directors, auditors, and shareholders. ${ }^{52}$ Enron's top executives and board of directors bear the primary blame. Yet the directors went though the motions dictated by the book of good corporate practice. Negative implications accordingly arise for the monitoring model of the board of directors. But, despite the author's disposition to draw regulatory inferences from business disaster, there follows no plausible reform prescription. Secondary blame attaches to Enron's auditors, who manifestly should have refused to give a favorable opinion on Enron's financials. Here arise the case's strong regulatory implications. It is clear that Enron had captured its auditor, denuding the relationship of its necessary adversary aspect. Similar situations of capture are ubiquitous in America's corporate landscape. Secondary blame also attaches to members of the community of institutional investors. Our self-regulatory system assumes that these actors make a governance contribution when they monitor large companies like Enron. Here they failed to do so even though Enron's financials provided enough information about shady deals to give them cause to demand explanations. If actors with billions of other people's money invested do not require managers and boards to make a coherent informational account of themselves before disaster strikes, despite clear signs of trouble, then we must put a heavy qualification on our reliance on the monitoring system. In contrast, the legal system will work as intended in this case so far as concerns ex post enforcement, given multiple prima facie violations of the securities

51. As they did so they shed the behavior pattern of the rational actor to display the behavioral infirmities described in learning on securities fraud. See Kimberly D. Krawiec, Accounting for Greed: Unraveling the Rogue Trader Mystery, 79 ORE. L. REV. 301 (2000); Donald C. Langevoort, Organized Illusions: A Behavioral Theory of Why Corporations Mislead Stock Market Investors (and Cause Other Social Harms), 146 U. PA. L. REV. 101 (1997) [hereinafter Langevoort, Organized Illusions]; Donald C. Langevoort, Selling Hope, Selling Risk: Some Lessons for Law from Behavioral Economics About Stockbrokers and Sophisticated Customers, 84 CAL. L. REV. 627 (1996) [hereinafter Langevoort, Selling Hope].

52. This leaves out a secondary list of participants, including Enron's counsel, Vinson \& Elkins, its creditors, particularly its lead lenders, and the investment institutions participating in its off-balance sheet vehicles. They will receive attention enough elsewhere. 
laws and an emerging picture of widespread culpability. ${ }^{53}$ The disturbing thing is that the system's standing army of civil and criminal enforcers had no deterrent effect.

Enron shows that the incentive structure that motivates actors in our self-regulatory governance system generates much less powerful checks against abuse than many observers have believed. This point does not by itself validate any particular regulatory corrective. The costs of any regulation can outweigh the compliance yield, particularly in a system committed to open a wide field for entrepreneurial risk taking. Such a system can no more break the iron law of risk and return than could Michael Milken and his junk bonds. If we seek high returns, we must discount for the risk that rationality and reputation will sometimes prove inadequate as constraints.

\section{ENRON AND THE CONTRACTARIAN IDEAL}

\section{A. The Virtual Corporation}

In early 2001, Enron was in a process of transformation, determined to leave behind its original business, an asset-laden producer and transporter of natural gas, to become a pure financial intermediary. Its intermediary business had two aspects. First, there was a proprietary marketplace in which Enron matched up energy producers, carriers, and users. ${ }^{54}$ Enron was expanding this business to cover anything which could be traded-pulp and paper, metals, even broadband services. There was reason for optimism-Enron had just started up an exemplary online operation which made access to its market cheap and user friendly. ${ }^{\text {ss }}$ Enron acknowledged few limits to its marketplace. Only "unique" products - "knickknacks"-_could not be brought within its trading model. ${ }^{56}$ Second, Enron sold risk management products. These over-the-counter derivative contracts covered its customers' exposure to price risks, making participation in Enron's market more attractive.

53. See William C. POWERS, JR. et AL., RePort of INVESTIGATION BY the SPECLAL INVESTIGATIVE COMMTTTEE OF THE BOARD OF DIRECTORS OF ENRON CORP. (2002), available at 2002 WL 198018 [hereinafter POWERS REPORT].

54. A back-office scheduled pipeline and transmission capacity to effect actual deliveries of gas and electricity. Zellner et al., supra note $12, \Uparrow 13$.

55. The site is said to have handled 550,000 transactions with a notional value of $\$ 345$ billion in its first year. A Survey of Energy: A Brighter Future?, ECONOMIST, Feb. 10, 2001, at 57, available at 2001 WL 7317640 [hereinafter Survey: Energy].

56. OnLine Extra: $Q \& A$ with Enron's Skilling, supra note 15. 
To get a better look at Enron's intermediary operation, let us hypothesize Enron's entry as a trader into a new market, say pulp and paper. To effect entry as a seller, Enron first had to assure itself of sources of supply, whether through contracting or through direct ownership of the sources of the product, here timber tracts. Once it established itself as a seller, Enron would start bringing other sellers together with timber buyers. As Enron saw it, such a new market could grow spectacularly if many timber users had captive sources of supply. In this scenario, the vertically integrated forest products companies notice the Enron market and see that it has sufficient volume to supply their needs. They begin to draw on it for marginal supplies. It becomes clear that Enron's market offers timber at lower prices than do their captive timber sources. Ultimately, these companies unbundle themselves, selling off their forest tracts, pocketing the gain, and relying on Enron's market for future supplies.

Enron claimed to provide a level of intelligence higher than that of a marketplace, traditionally conceived. As claimed in Enron's 2000 Annual report: "[We] provide high-value products and services other wholesale service providers cannot. We can take the physical components and repackage them to suit the specific needs of customers. We treat term, price and delivery as variables that are blended into a single, comprehensive solution."\$7

One key to this addition of value was diversification. Enron's network of contacts respecting supply of a given product caused a reduction of risk for buyers of the product, a risk reduction effect unachievable by isolated producer-sellers in an industry. Skilling explained:

[T] he fundamental advantage of a virtually integrated system vs. a physically integrated system is you need less capital to provide the same reliability. ... Nondelivery is a nonsystematic risk. If a pipeline blows up or a compressor goes down or a wire breaks, the bigger your portfolio, the greater your ability to wire around that.

So, if for example, I'm just starting in the gas merchant business and I'm selling gas from central Kansas to Kansas City, if the pipeline [between those places] blows up, I'm out of business. For Enron, if that pipeline blows up, I'll back haul out of New York, or I'll bring Canadian gas in and spin it through some storage facilities. If you can diversify your infrastructure, you can reduce nonsystematic risk, which says

57. ENRON, supra note 36, at 2. 
there's a ... very strong tangible network effect.... But you've got to get big, you've got to get that initial market share, or you're toast. ${ }^{\text {s. }}$

One obstacle to this market creation scenario concerned price risk to buyers. Product users who procure captive sources of supply seek insulation from price fluctuations, particularly upward price fluctuations in times of high demand. To divest one's source of supply and rely on a trading market, particularly another firm's proprietary trading market, is to expose oneself to this risk. The solution to the problem, for both Enron and the product user, lay in derivative contracts entered into with a market intermediary. These can provide protection against price increases at reasonable cost, at least for the short and intermediate durations. Thus did Enron supplement its activities as a market maker by entering into these contracts with its customers. As Enron stated in its 2000 Annual Report:

In Volatile Markets, Everything Changes But Us. When customers do business with Enron, they get our commitment to reliably deliver their product at a predictable price, regardless of the market condition.

This commitment is possible because of Enron's unrivaled access to markets and liquidity....

... We offer a multitude of predictable pricing options.

Market access and information allow Enron to deliver comprehensive logistical solutions that work in volatile markets or markets undergoing fundamental changes, such as energy and broadband. $^{59}$

Enron, in short, aspired to be better than a market. It was reducing the costs of finding, contracting with, and communicating with outside suppliers and customers-costs that formerly meant bringing disparate operations under a single corporate roof. From this there followed a staggering claim: Enron would apply enough raw intelligence and superior information to the provision of products and risk services to cause a change in the prevailing mode of industrial organization. Said Skilling:

There's only been a couple of times in history when these costs of interaction have radically changed.... One was the railroads, and then the telephone and the telegraph.... [W]e're going through another right now. The costs of interaction are collapsing because of the Internet, and as those costs collapse, I think the economics of

58. OnLine Extra: $Q \& A$ with Enron's Skilling, supra note 15 (alterations in original).

59. ENRON, supra note 36, at 6. 
temporarily assembled organizations will beat the economics of the old vertically integrated organization. ${ }^{60}$

Skilling continued, in a different setting:

The old way they reduced the risk is they'd vertically integrate. If you were Exxon in the old days, you integrated across the whole chain.... If you were afraid crude-oil prices would go down, you'd own the refinery, too, because you liked it if crude prices went down.... That made a lot of sense ... because it was very expensive to make sure you could get reliable supplies of crude oil to go into a refinery if you didn't own the crude oil.

Well, now you go on your computer and get it instantaneously.... If you have somebody [like Enron] who comes along and says hey, look, I'm going to virtually vertically integrate because it's a whole lot cheaper, you're not going to be cost-competitive. ${ }^{61}$

In Skilling's projection, virtual integration force would force Big Oil, Big Coal, or Big Anything to split up into multitudinous micro-firms, each working a niche. Enron would put the whole back together through its trading operation, all the while securing lower prices for all. $^{62}$

The "nexus of contracts" firm hypothesized by Jensen and Meckling in 1976 would be realized in fact. Jensen and Meckling took the large firm and explained it as a byproduct of equilibrium contracting by rational economic actors. Given the complexity of relations among actors in the complex, agency cost reduction emerged as the problem for solution in the economics of firm organization. ${ }^{63}$ Enron was going to use real-world market contracting to unwind Jensen and Meckling's contractual complexes into simpler, more transparent units. With each unit directly disciplined by the market for its own product, agency costs inevitably would be less of a problem.

Skilling saw one further implication: assets were a bad thing to have. This followed from the shareholder value maximization norm. Skilling liked the numbers on return on equity capital yielded by

60. Jerry Useem, And Then, Just When You Thought the "New Economy" Was Dead, Bus. 2.0, Aug. 2001, at 7.

61. OnLine Extra: $Q \& A$ with Enron's Skilling, supra note 15 (first four alterations in original).

62. Survey: Energy, supra note 55. For the path-breaking discussion of the virtual firm in the legal literature, see Claire Moore Dickerson, Spinning Out of Control: The Virtual Organization and Conflicting Governance Vectors, 59 U. PITT. L. REV. 759, 759-804 (1998).

63. Jensen \& Meckling, supra note 47, at 310. For an explication of the theory, see William W. Bratton, Jr., The New Economic Theory of the Firm: Critical Perspectives from History, 41 STAN. L. REv. 1471, 1478-80 (1989). 
financial institutions, insurance companies, and pension funds better than the returns capital yielded in the energy industry: "[ח]'s very hard to earn a compensatory rate of return on a traditional asset investment.... In today's world, you have to bring intellectual content to the product, or you will not earn a fair rate of return." ${ }^{94}$ Under this line of thinking, Enron could justify owning a bricks and mortar operation or other hard asset only to the extent necessary to support a trading operation - as with the timber tracts in the foregoing example or Enron's building of a national broadband network as the start point for a broadband trading market. Meanwhile, Enron would divest its extensive collection of pipelines and other properties. Wall Street applauded-here was a firm that "doesn't linger over troubled assets," dumping them in order to "help fund its vast ambitions."

It should be noted that Enron's plan to become the real-world embodiment of the contractarian ideal has profound implications for industrial organization. Of course, there is nothing new about restructuring, downsizing, and unbundling. These became everyday events in corporate America as the shareholder value maximization norm came to drive management decisions in the 1990s. But even as many corporations regrouped around "core competencies" they remained big, asset-rich entities, vertically integrating the production, supply, and distribution functions feeding in and out of their cores. Enron's vision held out a much more radical degree of divestiture, leading to smaller entities under tighter market constraints and deprived of institutional stability.

For a glimpse of the world Skilling envisioned for everybody else, we need only look within Enron's glass box in Houston to see the way he treated his own employees. Questions about executive decisions were not tolerated. Nor were fairness complaints. Employees labored under tremendous pressure to take significant risks and bring in favorable results in the short term. ${ }^{66}$ And the end justified the means. In 2000, Skilling publicly praised the employee who started Enron's online trading operation even though she had been explicitly forbidden to do $\mathrm{so}^{67}$ Said an officer present at that meeting:

64. OnLine Extra: $Q \& A$ with Enron's Skilling, supra note 15 (alteration in original).

65. Zellner et al., supra note 12.

66. John Schwartz, As Enron Purged Its Ranks, Dissent Was Swept Away, N.Y. TIMES, Feb. 4, 2002, at Cl.

67. John Schwartz, Darth Vader. Machiavelli. Skilling Set Intense Pace., N.Y. TnIES, Feb. 7, 2002, at C1. 
"The moral of the story is, 'You can break the rules, you can cheat, you can lie, but as long as you make money, it's all right.",\%s

Enron's whiz kid recruits entered a perpetual tournament, termed the "rank or yank" system. ${ }^{69}$ Each got to pick ten other employees to rank his or her performance. ${ }^{70}$ But the system also allowed coworkers to make unsolicited evaluations into an online database. ${ }^{71}$ At year's end, Skilling threw everybody's results onto a bell curve, and those on the wrong end of the curve were terminated. ${ }^{72}$ Those who remained scratched and clawed to get or stay in the winners' circle. ${ }^{73}$ Winners got million dollar bonuses and were privileged to accompany Skilling for glacier hiking in Patagonia or Land Cruiser racing in Australia. ${ }^{74}$

Differences between winners and losers within Enron became starker as 2001 unfolded. All of the employees became losers as their 401(k)s gave up a billion dollars in value. ${ }^{75}$ Management froze the plan accounts in October 2001, the same month Enron revealed a third quarter loss of $\$ 638$ million. $^{76}$ Meanwhile, top executives holding Enron stock, purchased through the stock option plan, were not similarly restricted and continued the heavy selling in which they had been engaged for some months. Sales of personal Enron stock yielded Kenneth Lay proceeds of $\$ 23$ million in $2001 .^{77}$ Redemptions of Lay's stock by Enron itself during the year netted him an additional $\$ 70.1$ million. ${ }^{\ngtr}$ Skilling sold $\$ 15.6$ million worth before he resigned and $\$ 15$ million thereafter. ${ }^{79}$ Amalgamated Bank, the plaintiff in a lawsuit against Enron's officers and directors, alleged gross sales of $\$ 1$ billion of Enron stock by its officer and director defendants over a three-year period."

68. Id.

69. Alexei Barrionuevo, Jobless in a Flash, Enron's Ex-Employees Are Stunned, Bitter, Ashamed, WaLl ST. J., Dec. 11, 2001, at B1.

70. Id.

71. Id.

72. Id.

73. Id.

74. See id.

75. Millon, supra note 7, at 8 .

76. Id. at 9.

77. Rachel McTague, Andersen Charges Enron with Withholding Key Information Affecting Balance Sheet 33 Sec. Reg. \& L. Rept. (BNA) 1770 (2001).

78. Joann S. Lublin, As Their Companies Crumbled, Some CEOs Got Big-Money Payouts, WALL ST. J., Feb. 26, 2002, at B1.

79. Richard A. Oppel, Jr., Former Head of Enron Denies Wrongdoing, N.Y. TIMES, Dec. 22, 2001, at C1.

80. Reed Abelson, Enron Board Comes Under a Storm of Criticism, N.Y. TIMES, Dec. 16, 2001, at MB4. 
We will see that Enron planted the seeds of its own destruction with its implementation of Skilling's "asset light" strategy. This, although a logical extension of the strategy-in-chief, was not necessary for its implementation. For the core of Enron's virtual firm strategy, then, the question remains: Has the strategy gone down with Enron, as Paul Krugman has asserted, or does a valuable arbitrage play remain on the table to be picked up by a successor?

\section{B. Enron's Virtual Corporation and the Theory of the Firm}

The theory of the firm suggests that value may indeed lie in the unbundling of vertically combined firms. The point follows directly from Ronald Coase's touchstone paper of 1937. Transacting on the market, said Coase, entails costs of learning and bargaining, costs that loom large in respect of long-term arrangements. Internalizing a production function economizes on these costs by interposing directions from a governance structure. But internalization carries its own costs stemming from increased rigidity and error. The boundary between the firm and the market lies at the point where transaction cost savings equal the incremental costs of rigidity and error. ${ }^{s 1}$ Viewed through the Coasian lens, Jeff Skilling's claims look almost modest. Enron, utilizing contemporary information technology, had put together a set of components-an information network, a derivative product line, and online access - which drastically reduced the cost of contracting for a range of products. Such a risk reduction causes the firm's boundary line to shrink and the zone of cost-effective arm's length contracting to expand. The shrinkage does indeed imply the unbundling of vertically integrated firms.

Coase's insight is further articulated in the contemporary property rights theory of the firm. This theory, like Coase's, suggests that beneath Enron's hyperbole there may indeed lie untapped sources of value.

Property rights theory asserts that long-term contractual relationships inevitably are incomplete; it never will be cost effective for parties to specify up front all future uses of productive assets. ${ }^{\mathrm{s}} \mathrm{A}$

81. R.H. Coase, The Nature of the Firm, 4 ECONOMICA 386, 390-95 (1937).

82. The theory puts human assets to one side, on the ground that they cannot be bought and sold and accordingly are not among the subject matter of firm contracts. The firm thus is conceived in terms of its nonhuman assets-fixed assets, client lists, intellectual property, and contract rights. Id.; Oliver Hart, An Economist's Perspective on the Theory of the Firm, 89 ColuM. L. REv. 1757, 1766-73 (1989). There is no necessary conflict between this perspective and Enron's vision of a proprietary market generated by human intelligence, unburdened by significant fixed assets. Enron was posing the profile of a contemporary 
problem follows. Absent an exhaustive set of terms, a party to a contractual relationship may be subject to a holdup-an action by the counterparty directed to the division of the relationship's ex post surplus. To the extent the relationship's structure invests a counterparty with bargaining power, the holdup diverts the surplus to that counterparty. The theory accordingly directs its attention to the ex post allocation of control over assets (hence the name "property rights"). The insight is that ex post bargaining power goes to the owner of the assets, and that the allocation of asset ownership therefore powerfully impacts productive incentives ex ante.

For an example of the theory's operation, consider the relationship between a Shipper $(S)$ and a Trucker $(T)$ hypothesized by the economists George Baker and Thomas Hubbard. ${ }^{83} S$ contracts with $T$ for a point-to-point haul from $A$ to $B$. An additional contract will be made for the back haul, from B to A or anywhere else, only to the extent $S$ needs that service at the time it makes the contract. Even if no back haul contract is entered into ex ante it remains possible that $S$ will need a back haul and will want such a contract after $T$ starts performing the point $\mathrm{A}$ to point $\mathrm{B}$ contract. If $T$ starts performing the contract without a back haul contract, $T$ will spend resources, including time, on a search for a back haul contract during performance of its contract with $S$. In addition, if $T$ finds a back haul contract and it turns out that $S$ needs a back haul when $T$ arrives at B, $T$ will be in position to use the back haul contract to bargain with $S$ for a greater share of the gains on the back haul. Meanwhile, $T$ is the party who maintains the truck. The question is whether $T$ should own the truck or $S$ should own the truck in a vertically integrated firm.

The answer depends on the facts. If $T$ owns the truck, $T$ bears all of the value consequences of decisions respecting maintenance; $T$ accordingly has a high-powered incentive to keep the truck well maintained and perform hauls so as to reduce wear and tear. If $S$ owns the truck, it may be rational for $T$ to slack off on maintenance because

financial institution against that of an old economy industrial. Financial institutions are built on assets just like industrials, it is just that contract rights and intangibles loom larger than physical things. Control of these rights leads to effective, if not direct, control over the human assets that make the business run. For a contrasting view of the theory of the firm, centered on human assets, see Benjamin Klein, Vertical Integration as Organizational Ownership: The Fisher Body-General Motors Relationship Revisited, 4 J.L. ECON. \& ORG. 199 (1988).

83. The discussion draws on Oliver Hart, Norms and the Theory of the Firm, $149 \mathrm{U}$. PA. L. REV. 1701, 1708-12 (2001), which draws in turn on GEORGE P. BAKER \& THOMAS N. HUBbaRd, NAT'l BUREAU OF ECON. RESEARCH, CONTRACTIBILITY AND ASSET ONNERSHIP: ON-BOARD COMPUTERS AND GOVERNANCE IN U.S. TRUCKING, WORKING PAPER NO. W7634 (2000). 
$T$ does not bear all of the value consequences. On the other hand, if $T$ owns the truck, $T$ will engage in back haul search activity, which is costly to $S$ even as $T$ keeps the truck well maintained. The vertical integration question comes down to a trade-off-the deadweight cost to $S$ of rent seeking by $T$ respecting the back haul versus the maintenance disincentives following from ownership by $S$.

Assume that rent seeking respecting back haul is very costly to $S$. $S$ accordingly internalizes the trucking function, and along with it the management problem of incentivizing its drivers to minimize wear and tear on the trucks. Now assume that Enron enters the trucking market, creating a cheap and accessible marketplace in which carriers and shippers buy and sell truck haul capacity. So long as maintenance remains a problem and the Enron market offers $S$ adequate capacity, the Enron market easily could prove substantially cheaper than the internally owned trucks. Divestiture therefore will make sense for $S$. The Enron market lowers the cost of search for $T$ and reduces $S$ s dependence on $T$ in the event a back haul becomes desirable to $S$, with the clear result that $T$ should own the truck.

More generally, property rights theory teaches that where two assets are sufficiently complementary and contracts respecting their deployment are sufficiently incomplete, common control dominates over separate ownership. Extreme complementarity obtains when, as between assets separately owned by two actors, neither actor can profit from increased output of either asset unless she has access to both; that is, absent the other asset, each is useless. ${ }^{84}$ In that case, integration is the only way to produce. Contrariwise, where complementarity is not extreme, a given asset by definition can be used for different purposes. Vertically to integrate a firm owning such an asset with another firm requiring only a subset of the possible uses, is potentially to sacrifice value. Since the owner-manager of the acquired firm loses ownership rights, there is a diminished incentive to invest in the asset on the part of those responsible for deploying the asset. ${ }^{85}$ Generalizing, as a firm's operations grow away from a core of complementary assets, there arise increasingly severe incentive problems respecting the peripheral assets. Productivity decisions at the periphery will tend to be directed in the interest of the core, a species of holdup.

At this point the theory yields a presumption against integration. Because integration in a large organization increases the number of

84. Hart, supra note 82 , at 1770 . Separate ownership only creates opportunities for holdups. Id.

85. Id. at 1767-68. 
potential holdups, absent significant gains from complementarity, nonintegration tends to be more productive than integration. ${ }^{86}$ Enron's business plan built on this latter point. The sudden appearance of a cheap and reliable trading market where none existed previously reduces complementarities among assets across the economy.

But universal unbundling does not necessarily follow. It all depends on particulars respecting costs in the case. As an example, consider a result yielded by Baker and Hubbard's trucking study. Their survey of the industry shows that $T \mathrm{~s}$ in need of back hauls resort to a thin spot market managed by brokers, and that rent seeking by $T \mathrm{~s}$ respecting back hauls is very costly to $S$ s. Meanwhile, the introduction of computer trip monitoring technology made it possible for $S \mathrm{~s}$ to draft incentive contracts with drivers that substantially ameliorate incentive problems respecting maintenance of $S$-owned trucks. In the market described by Baker and Hubbard, then, technological innovation caused the cost balance to tip toward internalization. ${ }^{87}$ This, of course, still leaves open the possibility that the introduction of a more efficient market for trucking capacity could shift the balance back.

In addition, it should be noted that complementarities among assets expand as investment in assets becomes relationship specific. Here consider the famous example of General Motors (GM), which manufactured cars, and Fisher Body, which manufactured car bodies, a principal component. ${ }^{88}$ The two firms became integrated after a period of relational contracting, in which Fisher proved unresponsive to GM demands for stepped-up production. Could Enron have solved their problems with an online market for car bodies? That would depend on numerous technical and cost factors. GM and Fisher became involved in a problematic relational contract because GM needed bodies manufactured according to its own specifications, which manufacture required a considerable start-up investment on the part of its supplier. ${ }^{89}$

86. Id. at 1770 .

87. See Baker \& Hubbard, supra note 83.

88. See Benjamin Klein et al., Vertical Integration, Appropriable Rents, and the Competitive Contracting Process, 21 J.L. \& ECON. 297 (1978).

89. In order to be induced to make the investment in the production facility, Fisher required a long-term purchase commitment from GM. The contract needed a price term that prevented GM from squeezing Fisher down to its variable costs after the costs were sunk. Fisher accordingly got a ten-year requirements contract, which priced the bodies on a costplus percentage basis, protecting GM from price gauging by Fisher. But then Fisher turned the tables on GM. A run-up in demand made it rational for GM to want Fisher to invest in a new plant. A new plant would mean a lower cost per unit. But that investment made no sense to Fisher, which would make more money producing with its old equipment at higher cost 
Once the supplier makes the investment, there results a significant complementarity. Nothing about a cheap, online business-to-business market guarantees the existence of products meeting particular specifications or of incentives to make buyer-specific investments.

Additional, intrinsic limitations on the Enron model should be mentioned. Enron's promise to provide the product over time at a predictable price can be fulfilled only to the extent that derivative hedges cost-effectively can insulate against price fluctuations. Such insulation comes cheapest on a short-term basis. Transaction costs go up as the duration extends to an intermediate term. Derivative protection on a long-term basis comes at a much more substantial cost. Such innovative, long-term contracts did figure into Enron's business. ${ }^{90}$ But as yet we have no performance track record for them, so their viability as a substitute for ownership remains to be proven. ${ }^{91}$ The upshot is that the Enron trading market was not yet a perfect substitute for vertical ownership. To the extent that a long-term price commitment is material, vertical integration still could dominate.

Finally, consider Oliver Hart's point that the greater the quantum of trust in the environment, the more actors can be expected to use the

under the cost plus formula. Finally, GM bought all of Fisher's stock. Klein, supra note 82 , at 200-02.

90. See The Fall of Enron: How Cold It Have Happened?: Hearings Before the United States Senate Comm. on Governmental Affairs, 107th Cong. (2002), at http://www.senate.gov/ gov_affairs/012402partnoy.htm (last visited Mar. 13, 2002) [hereinafter Enron Hearings] (providing testimony of Frank Partnoy, Professor of Law, University of San Diego School of Law).

91. Long-term derivative contracts implicate substantial problems of valuation. There also can be liquidity problems. Consider in this regard the story of Metallgesellschaft (MG), a large German company, that went to the brink of bankruptcy in 1994 following a misconceived hedge. The firm had sold a series of nonderivative, long-term, fixed-price delivery contracts for oil. These contracts resulted in a long-term exposure to a rise in the price of oil. MG only partially hedged this risk with long-term derivative purchase contracts, which trade in a thin market and tend to be illiquid. It made up the gap by buying short-term oil futures contracts and rolling them over every three months. The strategy behind this "false hedge" was as follows. For some years, short-term oil prices had been higher than long-term prices, and the two had moved up and down together. On this price pattern, a rise in prices would result in profits in the short-term futures market that covered MG's losses on its longterm forward contracts. But it did not work out that way. The price pattern broke abruptly when OPEC failed to agree on production cutbacks in the fall of 1993 . Short-term prices fell sharply, causing MG losses on the short-term positions. MG attempted to unwind the shortterm positions and shift to long-term hedges. But traders in the thin long-term market awaited it and the long-term price rose slightly. What had been modest profits on the hedge became a series of large losses, said to amount to $\$ 1.2$ billion. See Richard C. Breeden, Directors, Control Your Derivatives, WALl ST. J., Mar. 7, 1994, at A14; Metallgesellschaft: Not So Clever, ECONOMST, Jan. 15, 1994, at 83, 83. 
market and stay separate. ${ }^{92}$ The credibility of Enron's projections of a disintegrated future depended on a strong assumption about the trustworthiness of the substitute marketplace. It therefore appears that Enron's collapse does bear importantly on the credibility of predictions of future vertical disintegration. Enron's market was not a free public space in which buyers and sellers came together to transact directly with one another. It was instead an intermediary space owned and controlled by a single corporate entity. Such a market's viability as an alternative to ownership entirely depends on the corporate proprietor's financial health, validated by an investment-grade credit rating. Any buyer or seller materially relying on the existence of an Enron product market got a rude shock when Enron lost its credit rating due to concealed ill-health and tumbled into Chapter 11 two weeks later.

The foregoing analysis introduces some significant qualifications to the notion of the virtual firm. It thereby deflates Enron's pumpedup vision of microcompanies tied together by a single giant corporate intellect. But it does not at all rebut the suggestion that we could see significant disintegration beyond the 1990 s practice of corporate unbundling.

\section{ACCOUNTING FOR ENRON's COLLAPSE-FOUR STORIES}

\section{A. Enron as Conventional Market Reversal}

Enron's results for 1998, 1999, and 2000 suggest some interesting comparisons. The firm's revenues increased by $\$ 10$ billion from 1998 to 1999 , and by $\$ 60$ billion (to $\$ 100$ billion) from 1999 to 2000 . During the period, revenues contributed by Enron's old economy asset businesses-its pipelines and water companies-stayed stable. The revenue growth ${ }^{93}$ came from Enron's new economy trading business. Meanwhile, net after-tax income rose much more slowly, as the chart below shows. Pre-tax profits (not depicted on the chart) increased by $\$ 1$ billion in 1998, and then by only $\$ 500$ million in each of 1999 and 2000. These simple horizontal analyses suggest declining returns in

92. Hart, supra note 83 , at 1710 . It is noted that Hart shows that the point is not an absolute; on some scenarios trust favors a large organization. Id. at 1711-13.

93. Even with this simple point-the statement of revenues-there is a little bit of smoke and mirrors in the financials. Enron's spectacular revenue growth stemmed from the fact that when it effected a transaction, it followed the energy industry practice of booking the entire contract sale price as a revenue, instead of booking only its commission-accounting like a retailer rather than a broker-dealer. The cost to Enron of commodities traded are booked as expenses. The growth of expenses, termed "costs of gas, electricity, metal and other products," accordingly was just as spectacular as the growth of revenues-from $\$ 34.7$ million in 1999 to $\$ 94.5$ million in 2000. See ENRON, supra note 36, at 31 . 
the trading business. ${ }^{44}$ More particularly, even as Enron had opened more and more new trading territory, entrance barriers were low. As time went on, Enron had to deal with dozens of competitors who hired away its employees to compete in what had become its bread-andbutter business, undercutting its profit margins. According to one analyst, Enron's trading margins collapsed from $5.3 \%$ in early 1998 , to $1.7 \%$ in the third quarter of $2001 .^{95}$ Investor attention to the problem was deferred for a time because the California energy crisis and the attendant period of sky-high electricity prices led to extraordinary returns to all traders in that market. As California's prices dropped back to normal, Enron's shrinking trading returns became more apparent. ${ }^{96}$

ENRON STOCK PRICE/REVENUES/EARNINGS

(Source: Enron Annual Report 2000)

\begin{tabular}{|l|c|c|c|c|c|}
\hline & 1996 & 1997 & 1998 & 1999 & 2000 \\
\hline HIGH & 23 & 22.5 & 29 & 44 & 90 \\
\hline LOW & 17 & 17.5 & 19 & 28 & 41 \\
\hline $12 / 31$ CLOSE & 22 & 21 & 29 & 44 & 83 \\
\hline $\begin{array}{l}\text { REVENUE } \\
\text { (\$MILLIONS) }\end{array}$ & 13.2 & 20.2 & 31.2 & 40.1 & 100.7 \\
\hline $\begin{array}{l}\text { NET INCOME } \\
\text { (\$MILLIONS) }\end{array}$ & 493 & 515 & 698 & 957 & 1,266 \\
\hline
\end{tabular}

Enron's managers saw that rapid maturation of its new markets presented a problem for its growth numbers. Their strategy for dealing with it was to step up the process of market creation, moving into new commodities like pulp and paper, steel, and, most daringly, bandwidth. In addition, in 1999 they successfully launched EnronOnLine, an Internet-based commodity trading platform. But these initiatives did not make up for the shrinking returns in Enron's bigger volume energy trading business. And there was another problem. Good as they were at opening markets, Enron's managers were less adept at the old economy discipline of cost control. ${ }^{97}$ Indeed, extravagant spending was an everyday incident of life at the firm. ${ }^{98}$

94. Special Report, supra note 28, at 61-62.

95. Id.

96. Jenkins, supra note 12.

97. Bill Keller, Editorial, Enron for Dummies, N.Y. Times, Jan. 26, 2002, at A15.

98. Neela Banerjee et al., At Enron, Lavish Excess Often Came Before Success, N.Y. TIMES, Feb. 26, 2002, at C1. 
Bandwidth emerged as a special problem. Enron had invested $\$ 1.2$ billion to build and operate a fiber optic network. In 2001, it found itself with an operation with 1700 employees that devoured $\$ 700$ million a year with no sign of profitability. These numbers emerged just as severe overcapacity and financial distress hit the broadband business as a whole. The negative implications for Enron's stock price far outstripped the drain on cash flow. According to some outside analysts, when Enron's stock peaked in August 2000, priced at ninety with a price earnings ratio of sixty, a third of the price stemmed from expected growth in the broadband-trading operation. ${ }^{99}$

Old economy-related factors also contributed to Enron's problems. A number of big-ticket investments abroad-most prominently, the $\$ 3$ billion power plant in Dabhol, India, a $\$ 1.3$ billion purchase of the main power distributor to Sao Paulo, Brazil, and the $\$ 2.4$ billion purchase of the Wessex Water Works in Britain-all were performing badly. These global mistakes were adding up in public view..$^{100}$

Finally, Enron's managers, "laser-focused" on earnings as they were, had to keep an eye on its portfolio of "merchant investments." This contained many large block holdings of stock in technology and energy companies. Many of these positions were illiquid; hedges were either expensive or unavailable. ${ }^{101}$ Enron accounted for these investments as trading securities. Under this treatment, unrealized increases in the stocks' prices had flowed through to its income statement as gains. ${ }^{102}$ Thus had the rising stock market benefited Enron's numbers. A falling market would have the opposite effect, however.

The combination of the foregoing conditions and the stock market's general decline caused Enron's stock to fall precipitously even before resignations and scandals beset the company. The stock lost

99. Zellner et al., supra note 3, at 34-35.

100. Id. at 32. In mid-2000, Enron came close to dumping the lot in a sale to a group of wealthy Middle Eastern investors for a tidy $\$ 7$ billion. Unfortunately, the deal aborted. David Barboza, Enron Sought to Raise Cash Two Years Ago, N.Y. TMES, Mar. 9, 2002, at C1. A contract to sell Enron's interest in Wessex Water has been entered into the Chapter 11 proceeding, netting $\$ 777$ million in cash. Suzanne Kapner, Enron Selling Wessex Water for \$777 Million, N.Y. TMIES, Mar. 26, 2002, at C13.

After Enron's bankruptcy filing, it was alleged that Enron officers, seeking to protect its net earnings totals, point blank refused to write-off expenses booked as assets in overseas projects that had manifestly failed. Kathryn Kranhold, Enron Disputes Investors'Charge of Manipulated Cost Accounting, WALL ST. J., Apr. 9, 2002, at B7.

101. See POWERS REPORT, supra note 53, at 77-92.

102. HERWITZ \& BARRETT, supra note 8 . 
thirty-nine percent of its value in the first six months of $2001 .^{103} \mathrm{Had}$ Enron gone into Chapter 11 at this point in the story due to these factors (taken together with a recession), the story would be unremarkable. The distress would stem from garden variety risks and problems faced by all firms. Such failures bespeak erroneous business judgment and bad luck on the part of managers, but present no policy problem for business regulation. Enron captures our interest because these causes were necessary but not sufficient for its collapse, at least on the present state of the record. ${ }^{104}$

\section{B. Enron as Derivative Speculation Gone Wrong}

As we have seen, risk management through derivative contracting was a central component of Enron's trading business. These risk management services imply risks to the service provider. Enron nicely described these in its 2000 Annual Report:

Wholesale Services manages its portfolio of contracts and assets in order to maximize value, minimize the associated risks and provide overall liquidity. In doing so, Wholesale Services uses portfolio and risk management disciplines, including offsetting or hedging transactions, to manage exposures to market price movements (commodities, interest rates, foreign currencies and equities). Additionally, Wholesale Services manages its liquidity and exposure to third-party credit risk through monetization of its contract portfolio or third-party insurance contracts. Wholesale Services also sells interests in certain investments and other assets to improve liquidity and overall return, the timing of which is dependent on market conditions and management's expectations of the investments' value....

The use of financial instruments by Enron's businesses may expose Enron to market and credit risks resulting from adverse changes in commodity and equity prices, interest rates and foreign exchange rates. $^{105}$

The last sentence just quoted makes a critical point respecting the risk profile of firms that deal in derivatives. The degree of risk

103. Zellner et al., supra note 3 , at 33 .

104. The assertion in the text assumes that Enron's balance sheet and income statement figures respecting its trading and energy production operations were fundamentally sound. The assumption could turn out to be heroic. Analysts are already starting to ask questions. One, for example has been comparing numbers reported in regulatory filings with numbers Enron claimed to be generated by Enron OnLine, noting a huge discrepancy. Gretchen Morgenson, How 287 Turned Into 7: Lessons in Fuzzy Math, N.Y. Times, Jan. 20, 2002, at MB1.

105. ENRON, supra note 36, at 23, 28 (Management's Discussion and Analysis). 
exposure depends on whether the "rocket scientists" in the firm's derivatives department fully or partially hedge their positions. Anything other than full hedging can mean a loss (or windfall gain) in the event of price volatility. Management's Discussion and Analysis (MD\&A) in Enron's 2000 Annual Report makes a state-of-the-art governance assurance:

Enron manages market risk on a portfolio basis, subject to parameters established by its Board of Directors. Market risks are monitored by an independent risk control group operating separately from the units that create or actively manage these risk exposures to ensure compliance with Enron's stated risk management policies. ${ }^{106}$

What Enron's "stated risk management policies" actually said was not disclosed. Some observers of Enron's fall suspect that, whatever the "stated policy," the practice might have been imprudent. More particularly, they hypothesize that Enron's derivatives traders had been pumping up its earnings with bets that energy prices would rise. Such bets would have meant significant profits in 1999 and $2000 .^{107}$ In 2001, however, such betting would have meant significant losses as energy prices fell. ${ }^{108}$ On this scenario, Enron's fall mimics the 1998 case of Long-Term Capital Management, with two differences. Here the high-tech bets were on energy prices rather than on interest rates, as there, and here there was no bailout engineered by the Federal Reserve, as there.

Others press a different, but concomitant, derivative story. They allege that Enron's trading floor was a nest of corruption. The traders, it is said, routinely overstated their own trading profits, impelled no doubt by the tournament system's demand for good numbers. The traders also abused the fair value accounting that now applies to their operation. Under this, some derivative positions are "marked to market" (MTM) each reporting period. Under MTM accounting, even though the position remains open and gain or loss has not yet been realized, the firm's income statement reflects the gain or loss implied by the contract's current value. For over-the-counter derivatives, no trading market sets this figure. The contract's value must be derived

106. Id. at 27 (Management's Discussion and Analysis).

107. Professor Partnoy offers an analysis of Enron's income statement showing that all of its profits for its last three years came from derivatives. Enron Hearings, supra note 90 , Part III.C.

108. Enron's Fall: Upended, Economist, Dec. 1, 2001, at 65; Michael Schroeder \& Greg Ip, Out of Reach: The Enron Debacle Spotlights Huge Void in Financial Regulation, WALL ST. J., Dec. 13, 2001, at Al. 
from an economic model. Unfortunately, generally accepted approaches to valuation did not yet exist for many items in Enron's vast stock of innovative derivative products, particularly those with longer terms. An opportunity for income statement legerdemain resulted, and it is alleged that Enron's traders took liberal advantage. ${ }^{109}$

Similar accounting treatment, ${ }^{110}$ along with similar problems of speculative valuation, applied to Enron's long-term energy trading contracts. Here Enron aggressively exploited a special rule procured by the energy industry. Under this, the firm books estimated gains for the lives of long-term supply contracts on a present basis, rather than spreading the recognition of revenues over the lives of such contracts as would be done under conventional accounting. Indeed, it now appears that Enron marketed these and similar transactions to potential counterparties, selling accounting and tax treatments along with energy and financial products, with the treatments importing more substance than the transactions themselves. ${ }^{111}$

If some or all of the foregoing allegations turn out to be trueand many have turned out to be true already-then derivatives trading very well may have brought Enron down in 2002 or thereafter. But in 2001, when Enron filed for bankruptcy, none of the foregoing was known to the financiers and related actors who determined Enron's fate. Strictly speaking, then, a malfunctioning derivatives operation did not bring Enron down. ${ }^{112}$ Whether the lion's share of these allegations prove out remains to be seen. ${ }^{113}$

A cautionary, counterfactual note enters the story nonetheless: Even if Enron's derivative positions were appropriately managed, many observers were ready to believe the company to be a candidate for derivative distress in light of the direction of energy prices in 2001. Given that distress stemming from other quarters would make it difficult for Enron to maintain its credit rating and liquidity, and thus

109. Enron Hearings, supra note 90, Part III.C.

110. See Emerging Issue Task Force (EITF) Issue 98-10: Accounting for Contracts Involved in Energy Trading and Risk Management Activities.

111. See David Barboza, Enron Offered Management Aid to Companies, N.Y. TMIES, Apr. 10, 2002, at C1.

112. Cf. Michael Schroeder, As Enron's Derivatives Trading Comes Into Focus, Gap in Oversight Is Spotlighted, WALL ST. J., Jan. 28, 2002, at C1 (noting Professor Partnoy's testimony and noting the absence of oversight, but citing no corroboration of the allegations).

113. It bears noting that in January 2002, UBS Warburg purchased Enron's energy trading operation from the Chapter 11 debtor in possession, implying a judgment of soundness. On the other hand, that deal involved a contingent consideration. Daniel Altman, New Economy: Many Think that Enron's Business Model for Virtual Trading Remains Sound Despite the Company's Problems, N.Y. TIMES, Jan. 28, 2002, at C4. 
its relationships with contract and derivative counterparties, suspicions respecting derivatives exposure could not have helped matters. Enron's famously opaque financials only fueled suspicions.

If Enron's derivative operation turns out to have been corrupt, there arise two powerful regulatory implications. First, the Commodity Futures Modernization Act should not have exempted Enron and similarly situated firms from oversight. ${ }^{114}$ Second, the achievement of transparency respecting derivative positions for all financial intermediaries should take first place on the federal regulatory agenda.

\section{Enron as a Den of Thieves}

Disclosures of self-dealing transactions in the fall of 2001 seriously destabilized Enron. The disclosures concerned a complex of side deals involving two limited partnerships of which Enron's CFO, Andrew Fastow, was the manager of the general partner. These arrangements put $\$ 30$ million into Fastow's pocket, and resulted in an overstatement of Enron's earnings over four years of at least \$591 million. ${ }^{115}$ This Part starts with some accounting, laying out basic rules governing parents, subsidiaries, affiliates, and other entities and showing how those rules created problems for Enron's middle managers as they worked to realize Skilling's vision. The Part goes on to the Fastow arrangement and the $\$ 30$ million and finally turns to earnings manipulation.

\section{Accounting Rules and Chewco's Phantom Equity Investor}

Enron listed more than 3000 affiliated entities in its $10-\mathrm{K}$, variously accounting for them as consolidated subsidiaries, equity affiliates, and Special Purpose Entities (SPEs).

When one firm owns a majority of the stock of another firm, the accountants require the two firms' financial statements to be consolidated. The two firms' income numbers are combined and a common balance sheet shows all assets and liabilities. Transactions between the two firms drop out and do not generate revenues for either firm's income statement. Enron had many such subsidiaries. But subsidiaries did not figure prominently in Skilling's "asset light"

114. The Act should be amended to remove the "Enron Point" in any event.

115. The number comes from an Enron SEC filing. Bigger numbers now circulate. The Powers Committee would later suggest that $\$ 1.1$ billion is a more accurate figure for the overstatement respecting the Fastow partnerships. POWERS REPORT, supra note 53, at 127-28. 
restructuring program. Enron had to minimize the amount of debt appearing on its balance sheet in order to preserve its credit rating. The viability of its trading and derivatives operation depended on an investment grade endorsement. Accordingly, when Enron sought to enhance returns on an equity investment through heavy leverage, it made sure it owned less than a majority of the investee company. It had such fifty percent (and under) investments in an array of hardasset companies, which it termed "equity affiliates." Accounting for these stock holdings proceeded under the "equity method." Under this, the investee's financials are not consolidated; the investee's debt accordingly does not appear on the stockholder's balance sheet. On the other hand, intercompany transactions drop out and cannot generate revenues for either firm's income statement. Finally, the stockholder company shows a pro rata share of the investee's earnings on its income statement. ${ }^{116}$

A third accounting category permits a corporation to set up an unconsolidated affiliate and transact with it so that the profits from the transactions do flow through its income statement-the qualified Special Purpose Entity. SPEs tend to be high-leverage shells. The party in Enron's position (the "transferor" or "originator") transfers a financial asset to the SPE in exchange for consideration other than equity in the SPE. The SPE can raise the consideration for the asset transferred in any number of ways. If the asset has a rock-solid payment stream, it can borrow the consideration from a third party or in the public markets. It also can raise substantial outside equity capital. If the asset's creditworthiness is dubious, outside borrowing is precluded. But the SPE still can return its own debt paper to the originator. Multitudinous Generally Accepted Accounting Principles (GAAP) rules apply, mainly focused on the nature of the sales transaction between the originator and the SPE. ${ }^{117}$ There is also a critical SEC rule-three percent of the SPE's total capital must come from an outside equity investor, ${ }^{118}$ who must in addition have the power

116. See HERWIZ \& BARRETT, supra note 8, at 524-27.

117. A statement of the current accounting rules are set out in Statement of Financial Accounting Standards (SFAS) No. 140, Accounting for Transfers and Servicing of Financial Asserts and Extinguishment of Liabilities (Mar. 2001). The previous rules are set out in SFAS No. 125, Accounting for Transfers and Servicing of Financial Assets and Extinguishment of Liabilities (June 1996).

118. The three percent test is an SEC accounting rule. It originated in a 1991 letter of the Chief Accountant of the SEC issued in respect of a leasing transaction. The GAAP authorities are EITF Topic D-14: Transactions Involving Special Purpose Entities; EITF 9015: Impact of Nonsubstantive Lessors, Residual Value Guarantees, and Other Provisions in Leasing Transactions; EITF Issue 96-21: Implementation Issues in Accounting for Leasing 
to control the disposition of the asset in the SPE. ${ }^{119}$ This means that the outside equity holder must hold at least a majority of the SPE's equity. ${ }^{120}$ In addition, the outside equity holder's capital must be "at risk"-the originator cannot guarantee the investment's results. ${ }^{121}$ Finally, a legal determination as to the "bankruptcy remote" status of the SPE from the transferor also must be made. ${ }^{122}$ This all may sound a little sinister, but respectable firms use SPEs every day as vehicles for off-balance sheet securitization of financial assets such as accounts receivable and loan portfolios. In the case of accounts receivable, the transferor firm lowers its borrowing costs. ${ }^{123}$ In the case of a loan portfolio, the transferor firm gains liquidity and an opportunity to diversify its investments.

Enron used Fastow's limited partnerships as means to stay in compliance with the SPE rules. Fastow's entities served as the outside equity investor-the source of the qualifying three percent-for SPEs, which served no economic purpose other than to pump-up Enron's accounting earnings. As to entities such as these, arm's length outside equity investors understandably can be hard to find. The famous Chewco SPE, which preceded the Fastow limited partnerships in time and later figured independently in the Enron accounting scandal, illustrates the problem.

Transactions Involving Special Purpose Entities. The SEC insists that there is no bright line three percent test and that the level of outside funding should follow from the nature of the transaction. See David A. Kane, Remarks at the 28th Annual Conference on Current SEC Developments (Dec. 4, 2000) (on file with Tulane Law Review). The profession appears to treat the standard as a numerical rule, however.

119. Edmund L. Jenkins, Chairman, FASB, Testimony Before the Subcomm. on Commerce, Trade and Consumer Prot. of the Comm. on Energy and Commerce 9-10 (Feb. 14, 2002), available at http://www.fasb.org/news/testimony.pdf (last visited Aug. 22, 2002) [hereinafter Jenkins Testimony].

120. Id. If the equity participation is minimal-at the three percent level-then it must own $100 \%$ of the equity.

121. Id.

122. ERNST \& YOUNG, FinANCLAI REPORTING DEVELOPMENTS: ACCOUNTING FOR TRANSFERS AND SERVICING OF FINANCIAL ASSETS AND EXIINGUISHMENTS OF LIABIIITIESFASB STATEMENT 140, at 135-37 (2001).

123. See Steven L. Schwarcz, Structured Finance: The New Way to Securitize Assets, 11 CARDOZO L. REV. 607, 607-13 (1990). There is a policy debate respecting these transactions. The originator lowers its borrowing costs only so long as the SPE is "bankruptcy remote." Some argue that this imports an inappropriate priority to the SPE lenders to the detriment of preexisting contract creditors and all tort creditors of the originator. See, e.g., David Gray Carlson, The Rotten Foundations of Securitization, 39 WM. \& MARY L. REV. 1055, 1055-1120 (1998) (discussing securitization and bankruptcy law); Claire A. Hill, Securitization: A Low-Cost Sweetener for Lemons, 74 WASH. U. L.Q. 1061, 1077-1111 (1996) (same). 
Back in 1993, Enron set up a joint venture in energy investments with Calpers, the California state pension fund. It was called Joint Energy Development Investments (JEDI). In 1997, Skilling wanted Calpers to enter into an unrelated investment arrangement with Enron. Calpers was willing, but only if it first was cashed out of JEDI. A direct purchase by Enron of Calpers' fifty percent equity stake in JEDI was not an option. That would have meant turning JEDI into a wholly owned subsidiary of Enron whose debt would have to be consolidated on Enron's balance sheet. JEDI was heavily levered-its debt amounted to $\$ 1.6$ billion by $1999 .{ }^{124}$ To avoid that result, Enron formed an SPE, Chewco, and used Chewco to buy out Calpers. Chewco borrowed the money and Enron guaranteed the loan. ${ }^{125}$ Between 1997 and 2001, the Chewco arrangement permitted Enron to recognize $\$ 405$ million of revenues and gains respecting transactions with JEDI and Chewco. ${ }^{126}$

Everything would have been fine except for one little compliance problem. Enron had never gotten around to finding the three percent outside equity investor needed to qualify Chewco as an SPE. The Powers Report tells a sordid story here. Skilling wanted the Calpers takeout closed so quickly that Enron's middle managers had to fund Chewco's "equity" with a secret loan from Enron. A continued search for an equity investor after the Calpers closing proved fruitless. In the end, a sham transaction was constructed and concealed both from Enron's board and its auditor, Arthur Andersen. The transaction took a bank loan through some entities run by an Enron officer, Michael Kopper, and disguised the loan as an $\$ 11$ million equity investment in Chewco. ${ }^{127}$

The arrangement came to light within Enron in fall 2001, disqualifying its previous accounting treatment of Chewco and JEDI. Disqualification in fall 2001 meant consolidation of JEDI and Chewco

124. Some of the purchase price paid by Chewco also may have come from a loan by JEDI itself. John R. Emshwiller, Enron Transaction Raises New Questions, Wall ST. J., Nov. 5,2001 , at $\mathrm{A3}$.

125. Id.

126. POWERS REPORT, supra note 53, at 42; see also John Emshwiller, Andersen CEO Apparently Testified Inaccurately, WALL ST. J., Jan. 11, 2002, at A4.

127. See POWERS REPORT, supra note 53, at 41-47. Chewco became a limited partnership with Michael Kopper as the general partmer and Big River Funding LLC as the limited partner. The sole member of Big River was Little River LLC, of which Kopper's domestic partner was the sole member. Id. at 47. How this was supposed to get control of Chewco away from Enron is anybody's guess. The \$11.4 million loan was from Barclay's Bank. Although called a "funding agreement" yielding a "certificate," the substance was clearly that of a credit arrangement. Id. at 50; see also John R. Emshwiller \& Rebecca Smith, Joint Venture: A 1997 Enron Meeting Belies Officers' Claims They Were in the Dark, WALL ST. J., Feb. 1, 2002, at A1. 
with the result that Enron's earnings for 1997 through mid-2001 were retroactively reduced by $\$ 405$ million. ${ }^{12 s}$ Meanwhile, consolidation increased its total indebtedness by $\$ 628$ million. This was not the only such disqualification to occur in fall $2001 .^{129}$

Another JEDI transaction which came to light later should be mentioned. JEDI owned twelve million Enron shares, which it accounted for as trading securities. Unrealized gains on the stock thus flowed through to JEDI's income statement. Enron, accounting under the equity method with the approval of Andersen, then flowed fifty percent of that unrealized appreciation on its own stock over to its own income statement. In the first quarter of 2000 , Enron bootstrapped its way to $\$ 126$ million of revenue this way. But in 2001, when Enron's stock fell, no corresponding deductions flowed through! ${ }^{130}$ This was not the only way Enron used its own stock as a means to generate paper earnings.

\section{Fastow's $\$ 30$ Million}

In 1999, Andrew Fastow organized two limited partnerships, LJM Cayman, L.P. (LJM1) and LJM2 Co-Investment L.P. (LJM2). The entities were formed to participate as the outside equity investor in SPEs set up by Enron. Fastow controlled LJM1 and LJM2, serving as the managing member of their respective general partners. ${ }^{131}$ The arrangement involved an obvious conflict of interest. Enron would be doing transactions with entities controlled by its own CFO. But there was a justification. LJM1 and LJM2 promised to solve the compliance problem that had led to the under-the-table dealings respecting Chewco. ${ }^{132}$ At the same time, with Fastow in charge, transactions could be set up and executed smoothly and quickly. LJM1 and LJM2 were funded with outside equity-a long list of financial institutions contributed around $\$ 390$ million in exchange for limited partnership interests and a representation that these entities' privileged status meant the best Enron deals. The investors included J.P. Morgan, Chase, Citigroup, Credit Suisse, First Boston, and Wachovia;

128. POWERS REPORT, supra note 53 , at 42.

129. Enron Form $8-K$, filed Nov. $8,2001, \S 2 . B$.

130. POWERS REPORT, supra note 53, at 58-59.

131. With LJM2 there were two tiers of general partners between Fastow and the limited partnership. Id. at 73-74.

132. The Powers Report questions whether an adequate separation of control ever really was achieved. Id. at $75-76$. 
employees of Merrill Lynch (which had marketed the interests) also kicked in $\$ 22$ million. ${ }^{13}$

A scandal resulted when the terms of the transactions between Enron and the SPEs in which LJM1 and LJM2 made the three percent equity investments were fully disclosed to the public in October 2001. An analytically distinct problem arose for Enron with the disclosure that Fastow had raked in $\$ 30$ million from compensation arrangements respecting his management of the limited partnerships. The SEC launched an investigation on October 22. Fastow got the sack two days later. He has since retained David Boies. ${ }^{134}$

The vociferous reaction to Fastow's self-dealing suggests a tentative explanation of Enron's failure centered on a loss of confidence. An old economy, hard-assets firm can weather this sort of disclosure by causing heads to roll and bringing in heavyweights from outside to clean up. Enron, however, had ceased to be a hard-assets company. Its survival depended on its trading operations, the success of which required trust and confidence among Enron's counterparties. The scandal in the wake of the self-dealing disclosure amounted to an external shock to the structure of confidence Enron had erected over many years. The firm went down with the structure, much like Drexel Burnham Lambert's ${ }^{135}$ collapse of a decade ago in the wake of the proceedings against Michael Milken.

This neat story gives rise to a number of questions. First, LJM1 and LJM2 and Fastow's role in them were not exactly news in the fall of 2001. They had been disclosed in footnote 16 of Enron's 2000 financials. Now, this disclosure was not a model of clarity. Fastow is not mentioned by name and the paragraphs offer only a scattershot and cursory description of the dealings back and forth. But the types of transactions between Enron and the LJM-related SPEs are clearly stated, along with the magnitude of the numbers involved. ${ }^{136}$ Footnote 16 reports:

(a) that Enron had transferred to the LJM-related SPEs more than $\$ 1.2$ billion in assets, including millions of shares of Enron common

133. John R. Emshwiller et al., How Wall Street Greased Enron's Money Engine, WALL ST. J., Jan. 14, 2002, at C1.

134. Enron's board went into the time-honored crisis mode and appointed a special committee of outside directors. This was led by William Powers, the Dean of the University of Texas School of Law, appointed to the board for the occasion. The committee thereinafter retained Wilmer, Cutler \& Pickering and Deloitte \& Touche for legal and accounting advice. Enron Form 8-K, supra note $129, \$ 4$.

135. Also an Arthur Andersen client.

136. ENRON, supra note 36, at 48; see also ENRON, 1999 ANNUAL REPORT 59 (2000). 
stock and long-term rights to purchase millions more shares, plus $\$ 150$ million of Enron notes payable;

(b) that the SPEs had paid for all of this with their own debt instruments with a face amount of $\$ 1.5$ billion; and

(c) that the SPEs had entered into derivative contracts with Enron with a notional amount of $\$ 2.1$ billion. ${ }^{137}$

One has to turn to Enron's 2000 proxy statement to see Fastow identified. The proxy statement discloses that Fastow will be remunerated by a "percentage of the profits . . . in excess of the general partner's proportion of the total capital contributed to [the partnership] depending on the performance of the investments made."138 No actual numbers are given, but we are told

(a) that "management believes that the terms ... were reasonable and no less favorable than the terms of similar arrangements with unrelated third parties," and

(b) that actors other than Fastow negotiated the transactions for Enron. ${ }^{139}$

Enron's November 2001 Form 8-K adds that Enron's board had reviewed the matter of Fastow's affiliation and determined it not to be injurious to Enron's interests. Continuing controls were imposed-each LJM transaction had to be approved by the Chairman and two additional top officers, and the Audit Committee was to conduct an annual review. ${ }^{140}$

The Powers Committee report on LJM1 and LJM2, released in February 2002, later would establish beyond peradventure that the transactions between Enron, the SPEs, LJM1, and LJM2 involved breaches of fiduciary duties owed by Fastow and others to Enron. ${ }^{141}$ Terms of many sales contracts were skewed to favor LJM (and thus

137. ENRON, supra note 36 , at 48 .

138. Enron Schedule 14A, filed Mar. 21, 2000, at 26.

139. Id. at 25-26.

140. Enron Form $8-\mathrm{K}$, supra note $129, \S 5 . \mathrm{A}$.

141. The most outrageous occurred in connection with the termination of LJM1. Fastow caused the "termination interests" to be directed to a partnership called Southampton Place. As a partner, Fastow made $\$ 4.5$ million over two months based on a negligible investment. Two other Enron officers made \$1 million each. POWERS REPORT, supra note 53, at 16. Those involved in the Southampton caper and still with the company on November 8, 2001 were fired that day. Enron Form 8-K, supra note 129, $\$ 7$.

Fastow had sold his interests in LJM1 and LJM2 in July 2001 to Michael Kopper. Unlike Fastow, Kopper resigned from Enron in connection with his purchase of the interests. Enron Form 8-K, supra note 129, \$ 5.A; see also Joann S. Lublin \& John R. Emshwiller, Enron Board's Actions Raise Ljability Questions, WALL ST. J., Jan. 17, 2002, at C1. 
Fastow's equity interest). As a result of this, returns to LJM's outside equity investors were quite fantastic. ${ }^{142}$

But no one knew any of this on October 17, 2001, when the only news was the fact that returns to Fastow amounted to $\$ 30$ million. Given that previous disclosures held out the possibility of a significant upside possibility for Fastow, why all the brouhaha? As a matter of corporate law, deals like this do not breach fiduciary duties on a per se basis. ${ }^{143}$ If we follow the Delaware cases, the disinterested directors' approval means that a plaintiff seeking to make out a breach of the duty of loyalty has to bear the burden of showing that the transactions were unfair. ${ }^{144}$ Unfairness obtains only if Fastow's $\$ 30$ million was out of line with the returns of managers of comparable limited partnerships, or if plaintiff could show that the terms of the transactions between Enron and LJM unduly favored LJM. In October 2001, neither situation obtained on the face of the public record. ${ }^{145}$ Given the large numbers involved in the Enron-LJM SPE transactions and a practice of large rewards for promoters of private equity schemes, a finding of fiduciary breach respecting the $\$ 30$ million taken by Fastow would have seemed unlikely, absent Enron's other problems.

We can draw several lessons from the fact that, despite all of this, disclosure of the $\$ 30$ million taken alone caused a scandal. First, contrary to the efficient market hypothesis, ${ }^{146}$ actors in the financial

142. See, e.g., POWERS REPORT, supra note 53, at 103-04 (discussing returns on LJM2).

143. However, many, including the author, think they should. For a discussion of the Delaware law implications of Enron, see Leo E. Strine, Jr., Derivative Impact, Some Early Reflections on the Corporate Law Implications of the Enron Debacle (2002) (working paper, on file with author).

144. See Cooke v. Oolie, No. 11,134, (Del. Ch. June 23, 1997), 23 DeL. J. Corp. L. 775 (1998). Enron is an Oregon corporation. Cooke is referenced because it interprets a statute worded very similarly to OR. REV. STAT. $\$ 60.361$ (1999), which governs self-dealing transactions.

145. Much is made of the fact that LJM2's marketing materials asserted that, because of the insider tie, LJM2 would get the best Enron SPE transactions. See Henriques \& Eichenwald, supra note 8, at MB1.

It is noted that Fastow, in one presentation on LJM, represented that partnership matters took up only three hours of his time per week. Emshwiller \& Smith, supra note 127, at A1.

146. The strong form of the efficient market hypothesis asserts that all information is incorporated into the stock price; the semi-strong form asserts that the price reflects all publicly disclosed information. VICTOR BRUDNEY \& WILLIAM W. BRATTON, CORPORATE FINANCE: CASES AND MATERIALS 128-30 (4th ed. 1993). Even in descriptions of market pricing that acknowledge considerable departures from efficiency, it is generally thought that stock prices are particularly likely to be accurate given a thick trading stock and a large market capitalization, both of which obtained with Enron. See Ronald J. Gilson \& Reinier H. Kraakman, The Mechanisms of Market Efficiency, 70 VA. L. Rev. 549, 622-26 (1984). Of 
markets are selective so far as concerns assimilation of facts rendered in fine print sections of financials and other SEC documents. Second, the strength of the norm against self-dealing brought to bear in the financial community varies with corporate results. On the upside, no one pays much attention. The operative norm is that of the corporate law duty-self-dealing transactions are acceptable so long as the consideration stays in the same ballpark as that of comparable transactions. Since everyone is making money, magnanimity makes sense. Disturbing the side deal could destabilize a productive employment arrangement. ${ }^{147}$ On the downside, everything is different. The same officer touted as an entrepreneurial genius on the upside starts to look like a thief and his or her self-dealing transaction causes a scandal even though it already was disclosed.

This could be called scapegoating. It is defensible nonetheless. The officer who succumbs to temptation on the upside assumes the downside risk of reputational ruin. The financial community and the law only tolerate self-dealing transactions as a matter of expediency. Beneath that tolerance runs a strong norm of aversion which can rear its head viciously in bad times. Neither Andy Fastow nor any other self-dealing corporate actor plausibly can express surprise when a spate of red ink triggers his or her denunciation as a miscreant. Legal liability easily could follow: The transaction that did not breach the duty of loyalty when entered into in good times can breach the duty by virtue of the fact that unrelated subsequent events make it look unfair to an ex post decision maker. ${ }^{148}$

course the $\$ 30$ million figure was new, but the previously disclosed facts implied such a figure, at least to an audience of sophisticated investors.

147. See Cookies Food Prods., Inc. v. Lakes Warehouse Distrib., Inc., 430 N.W.2d 447, 455-56 (Iowa 1988) (concluding that self-dealing contracts costing more than comparable contracts were not unfair because they incentivized a successful entrepreneur).

148. There is also a lesson here for the corporate law academics who have debated back and forth the question whether fiduciary constraint of self-dealing transactions should continue to be mandatory or should be downgraded to contractual status as a liability regime into which corporations opt in their charters. Compare Frank H. Easterbrook \& Daniel R. Fischel, The Corporate Contract, 89 ColuM. L. REV. 1416, 1434-48 (1989) (arguing for opting out with process controls), with Jeffrey N. Gordon, The Mandatory Structure of Corporate Law, 89 CoLuM. L. Rev. 1549, 1593-97 (1989) (arguing that contract failure is probable with broad brush opting out of fiduciary duties). Unfortunately, Enron's case will not end the argument. It instead raises two conflicting inferences. On the one hand, the vehemence of the financial community's imposition of the norm against Fastow suggests that contractual treatment may suffice. Such a deeply and widely held aversion to self-dealing arguably needs no support from a mandatory legal regime. The reputational ruin awaiting those who traverse the norm should more than suffice as a deterrent. On the other hand, Enron's demonstration of the norm's power supports the mandatory regime. If there were no widely held norm against self-dealing, mandatory fiduciary liability would be of dubious 
To sum up on Fastow and his $\$ 30$ million, this previously disclosed self-dealing transaction, taken alone, makes an implausible candidate for a leading role in an account of Enron's collapse. For that we must look to the broader terrain of Enron's dealings with its SPEs and affiliated companies.

\section{SPEs and Overstated Numbers}

The confidence-based account of Enron's collapse becomes more compelling with a closer look at transactions between Enron and the SPEs related to LJM1 and LJM2. ${ }^{149}$

\section{a. The Watered Stock}

Recall that Enron funded the LJM-related SPEs with $\$ 1.2$ billion of its own common stock, along with other assets, exchanged for debt instruments of the SPEs. A century ago, corporate law barred such transactions, prohibiting the use of debt or other promissory consideration in connection with the issue of new common stock. ${ }^{150}$ The risk that insiders would take the stock and enjoy an upside play without ever delivering on their promises was deemed great enough to support a per se prohibition. Today corporate law has a more relaxed attitude, remitting the decision as to the adequacy of the consideration

legitimacy. Indeed, given charter competition's historical role in assuring that legislatures remove outmoded mandates from corporate codes, the self-dealing mandate already would have disappeared from the law if it lacked normative support. Meanwhile, the norm makes it implausible to contend that the ancillary costs of fiduciary litigation carry no compensating benefit-vindication of the norm is a benefit. Finally, just as the norm imports substantive support for the mandate, so does the mandate support the norm, serving as a backstop enforcement mechanism. No more than a backstop appears to be needed-empirical studies of corporate law litigation show that only a very small number of shareholder derivative actions are brought in respect of self-dealing transactions. See Roberta Romano, The Shareholder Suit: Litigation Without Foundation?, 7 J.L. ECON. \& ORG. 55, 58-60, 84 (1991) (showing small numbers of derivative actions). Of course it can be argued that these small numbers merely show the norm's independent prohibitive force. But that point just as easily can be modified so that the small numbers are seen to stem from the combination of the norm's power and the certainty of enforcement against violators.

149. Only with the Powers Report, supra note 53, did the public get a complete record of these transactions. The description in Enron's 2000 Annual Report was unhelpful. The details that led to a scandal and contributed to Enron's bankruptcy were set out in Enron's corrective filings with the SEC in November 2001. The famous letter to Lay written by Enron vice president Sherron Watkins also discussed these transactions. Text of Letter to Enron's Chairman After Departure of Chief Executive, N.Y. TIMES, Jan. 16, 2002, at C6 [hereinafter Watkins Letter].

150. See Bayless Manning, A Concise Textbook on Legal Capital $41-42$ (2d ed. 1981). 
to the discretion of the board of directors. ${ }^{151}$ Accountants retain a healthy suspicion: Notes received in exchange for a company's own common stock must be booked as deductions from shareholders' equity. ${ }^{152}$ The newly issued stock is credited to the capital stock account at the purchase price, but the capital stock accounts elsewhere are debited (reduced) in the amount of the note. The result is a wash at the time the note is issued. As the note is paid, the reduction gradually is reduced, with a corresponding net increase to the shareholders' equity account. ${ }^{153}$

Such niceties, however, did not fall within the purview of Enron's aggressive accounting practices. When it capitalized the LJM-related Raptor I-IV SPEs, Enron booked the notes issued by the SPEs as assets on its balance sheet and increased its shareholders' equity in a like amount, as one would do when selling newly issued common stock for cash in a public offering. Enron and Andersen later thought better of the treatment. Unwinding it meant the sudden and highly embarrassing disappearance of $\$ 1.2$ billion from Enron's net shareholders' equity. ${ }^{154}$

Significantly, the matter at least had been mentioned in the footnotes to Enron's 2000 financials. We see the stock going into the SPEs, and then some sentences later we read of "a special distribution from the Entities in the form of $\$ 1.2$ billion in notes receivable."15s

151. See, e.g., MODEl Bus. CoRP. ACt $\S 6.21$ (b)-(c) \& cmt. 1 (discussing board of directors' determination of adequacy of consideration for shares).

152. EITF Issue No. 85-1: Classifying Notes Received for Capital; SEC Staff Accounting Bulletin No. 40, Topic 4-E: Receivables from Sale of Stock; 17 C.F.R. Part 211B (2002); see also Jenkins Testimony, supra note 119, at 22.

153. Say stock is issued in exchange for a $\$ 1000$ note payable. At issue the following entries are made in the shareholders' equity section:

Note Receivable from Issue of Shares Capital Stock

$\$ 1000$

$\$ 1000$

When the Note is paid, two entries follow:

Cash

Note Receivable from Issue of Shares

$\$ 1000$ Note is paid. GAAP extends this skepticism to accounting for all speculative debt paper, under the installment and cash recovery methods. See HERIVTZ \& BARRETT, supra note 8, at 494-97.

154. Enron Form 8-K, supra note 129, § 3. See also Powers Report, supra note 53, at 125-26, which notes that Andersen was ready to deem the mistake immaterial.

155. ENRON, supra note 36, at 48. 
b. The Equity Swaps that Weren't

Enron used the LJM-related SPEs-Talon and the Raptors IIV-as counterparties in equity swaps. ${ }^{156}$ The swaps hedged Enron's exposure to downside risk on large block positions of publicly traded equity it held in its "merchant" portfolio. Enron needed hedges of these exposures to protect its income statement. Because the stocks were accounted for as trading securities, any unrealized decreases in their market values were deducted from Enron's net earnings. So far so good: It is normal for holders of large, undiversified equity stakes, such as executives holding sizable positions in their own companies' stock, to enter into such contracts. Ordinarily this is done with a financial institution for a short or intermediate term. To describe a very simple transaction, if the stock subject to the swap goes up during the period of the swap, the executive pays the bank the amount of the price increase. Because the executive's own block of stock has gone up as well, the transaction is a wash so far as the executive is concerned. ${ }^{157}$ If the stock goes down, the bank pays the amount of the decrease to the executive. The bank in turn hedges its downside risk on the stock by selling the stock short or purchasing a put option on the stock. ${ }^{158}$

The LJM-related SPEs acted in the position of the financial institution. But they did not make hedging contracts to cover their exposure in the event the stock subject to the swap lost value. Such contracts would have been expensive if available at all. Instead, the Enron common stock (issued in exchange for the SPE notes) used to fund the SPEs was to cover any SPE loss on the swap.

The Enron portfolio stocks under the swap did lose value. Enron set up the swaps just as the subject stock prices hit peaks. According to the Powers Report, the value of the portfolio under the swaps fell by $\$ 1.1$ billion across five fiscal quarters, so that the SPEs owed Enron $\$ 1.1$ billion under the contracts. Enron, using the new "fair value" accounting, marked the value of its rights under the swap contracts to

156. The account in the text draws on Enron Form $8-\mathrm{K}$, supra note 129, $\$ 5 . A$, Sherron Watkins' Letter to Lay, Watkins Letter, supra note 149, and the Powers Report, supra note 53.

157. In the real world, the executive may swap for the return on some other investment, for example the return on a market portfolio such as the S \& P 500 or a portfolio of bonds.

158. Shorting the underlying stock means borrowing shares to cover the position. In order to borrow the shares, the short party must provide collateral, which will be cash. The party lending the shares and holding the cash collateral pays interest on the cash, at rate slightly under LIBOR. The bank pays this interest over to its swap customer, but at an even lower rate, pocketing a spread (around thirty basis points, depending on the customer). This in effect is the bank's fee. 
market for income statement purposes. Enron's reported numbers are lower than the later Powers figures: Enron's Annual Report for 2000 showed a $\$ 500$ million gain on the swap contracts, which exactly offset its loss on the stock portfolio. This $\$ 500$ million made up about one third of Enron's earnings for 2000 (prior to restatement in 2001).

Problems arose. The Enron common stock used to fund the SPEs with capital to support the swaps also started falling. Where its value fell below the SPE's exposure on the swap, the SPE was technically insolvent. There resulted a series of improvised restructurings of the transactions, carried out by Enron's middle managers and concealed from its board of directors. ${ }^{159}$

Worse, the whole transaction structure followed from a very faulty premise. The stock protected by the swaps was not going to go back up. The SPEs had not hedged, so that, under the deal, their losses on the stock would have to be covered by the stock issued by Enron. Collapsing everything into one transaction, Enron was issuing its own common stock to itself to cover its own income statement loss, thereby increasing its own net earnings over the life of the swaps by a total figure in excess of $\$ 500$ million ( $\$ 1.1$ billion according to the Powers Report).

This one may not do under the most basic rules of accounting, indeed, under the most basic rules of capitalism. One issues stock to raise capital. One then uses the capital to do business and generate income. One cannot skip this step and enter the capital stock directly into income. The value of a firm stems from its ability to take the capital and earn money over time; its stock market capitalization reflects projections of its ability so to do. Here Enron perverts the system, using its market capitalization-the value of its common stock-to support the value of its common stock.

At Ken Lay's direction, Enron folded the SPEs and the swaps in the third quarter of 2001, restating past earnings downward by almost $\$ 600$ million. It had at least noted the arrangement in the footnotes to its 2000 Annual Report. The Report tells us of the hedges, and we see that Enron owes the SPEs "premiums" totaling \$36 million. Further, "Enron

159. POWERS REPORT, supra note 53, at 98 . In one particularly egregious arrangement, Enron's middle management had no Enron stock available to fund the SPE. Instead of going to the board to get more authorized, they funded the SPE with a block of the same stock being hedged by the swap. Needless to say, the SPE became insolvent rather quickly when the stock went south. Id. at 114-15. The stock in the SPE was that of The New Power Company, an Enron startup slated to market power directly to consumers. The enterprise flopped rather badly. See Rebecca Smith, Short Circuit: How Enron's Plan to Market Electricity Nationwide Fizzled, WALL ST. J., Mar. 25, 2002, at Al. 
recognized revenues of approximately $\$ 500$ million related to the subsequent change in the market value of these derivatives, which offset market value changes of certain ... investments." ${ }^{\text {"160 }}$ However, we are not told how the SPE will be covering its $\$ 500$ million loss exposure.

Nor are we told why "premiums" were due and owing. It took the Powers Report to clear that up. Fastow negotiated a deal for LJM that guaranteed a windfall profit out of each SPE even before a single swap was put in place. The SPE would write a put on its Enron common stock and sell the put to Enron. Enron would pay a premium on the put at the market rate for such a contract. The SPE transferred the premium to LJM as an immediate return on capital. For example, with LJM1 and the Talon SPE, this was a $\$ 41$ million payment, making for a $193 \%$ annualized return on the LJM investment. ${ }^{161}$

ENRON-THE COURSE OF EVENTS, $2001^{162}$

\begin{tabular}{|l|l|l|}
\hline DATE 2001 & $\begin{array}{l}\text { STOCK } \\
\text { PRICE }\end{array}$ & Event \\
\hline January 1 & 83.12 & \\
\hline February 12 & 79.80 & Skilling named CEO \\
\hline March 26 & $\begin{array}{l}\text { LJM transactions restructured; } \\
\text { Chewco closed out }\end{array}$ \\
\hline April 17 & 60 & $\begin{array}{l}\text { First quarter profits of \$536 } \\
\text { million announced }\end{array}$ \\
\hline May 5 & 59.78 & Skilling resigns \\
\hline August 14 & 43 & $\begin{array}{l}\text { Sherron Watkins delivers letter to } \\
\text { Lay }\end{array}$ \\
\hline August 15 & 40.25 & $\begin{array}{l}\text { Third quarter loss of \$618 million } \\
\text { announced }\end{array}$ \\
\hline October 15 & 33.17 & 33.84 \\
\hline October 16 & &
\end{tabular}

160. ENRON, supra note 36 , at 48 .

161. POWERS REPORT, supra note 53, at 103-04. The Powers Report also shows numerous additional earnings manipulations carried out through LJM-related SPE transactions. Enron transferred financial assets to the SPE at prices favorable to Enron right before the expiration of a fiscal quarter. In many of these cases, the SPE would later transfer the asset back to Enron at an assured profit. Id. at 128-44. A family resemblance to the real estate flips of Charles Keating and the Lincoln Savings \& Loan is noted. See Lincoln Sav. \& Loan Ass'n v. Wall, 743 F. Supp. 901, 905-19 (D.D.C. 1990).

162. Robert L. Bartley, Editorial, Enron: First, Apply the Law, WaLL ST. J., Feb. 11, 2002, at A23; Kurt Eichenwald \& Diana B. Henriques, Web of Details Did Enron In as Warnings Went Unheeded, N.Y. TMES, Feb. 10, 2002, at 1; Emshwiller, supra note 124, at A3. 


\begin{tabular}{|l|l|l|}
\hline DATE 2001 & $\begin{array}{l}\text { STOCK } \\
\text { PRICE }\end{array}$ & Event \\
\hline October 17 & 32.20 & $\begin{array}{l}\text { Rumors of \$1.2 billion equity } \\
\text { write-off circulate on Wall Street }\end{array}$ \\
\hline October 17 & 32.20 & 401(k) plans frozen \\
\hline October 17 & 32.20 & $\begin{array}{l}\text { Wall Street Journal reports Fastow } \\
\text { rake of \$30 million }{ }^{163}\end{array}$ \\
\hline October 18 & 29.00 & $\begin{array}{l}\text { Wall Street Journal reports the } \\
\text { \$1.2 billion write off }\end{array}$ \\
\hline October 22 & $\begin{array}{l}\text { SEC launches investigation of } \\
\text { Enron accounting }\end{array}$ \\
\hline October 24 & 16.41 & Fastow terminated \\
\hline October 25 & 16.35 & $\begin{array}{l}\text { Merger discussions with Dynegy } \\
\text { commence }\end{array}$ \\
\hline October 31 & 13.90 & $\begin{array}{l}\text { Form 8-K filed; reveals LJM and } \\
\text { Chewco earnings write-offs }\end{array}$ \\
\hline November 8 & 8.41 & $\begin{array}{l}\text { Dynegy merger agreement } \\
\text { executed and delivered }\end{array}$ \\
\hline November 9 & 8.63 Fidden \\
\hline November 19 & 9.06 & $\begin{array}{l}\text { Form 10-Q filed; reveals hidden } \\
\text { guarantees, cash flow crisis }\end{array}$ \\
\hline November 28 & 0.61 & $\begin{array}{l}\text { S\&P downgrades Enron to junk } \\
\text { status }\end{array}$ \\
\hline November 28 & 0.61 & Dynegy cancels merger \\
\hline November 30 & 0.26 & Chapter 11 filing \\
\hline December 2 & 0.40 &
\end{tabular}

\section{c. Summary}

At around the same time Enron revealed the aforementioned downward restatements of its previously reported results, Enron announced a 2001 third quarter loss of $\$ 618$ million (compared with around $\$ 300$ million profits a year earlier). Just looking at the numbers for the year 2000 , the downward adjustment due to LJMrelated entries was $\$ 519.9$ million, a significant number in view of the fact that Enron's restated net earnings for 2000 amounted to only $\$ 847$ million. ${ }^{164}$ The problem went beyond the numbers, which were not

163. John Emswhiller \& Rebecca Smith, Enron Jolt: Investments, Assets Generate Big Loss, WALl St. J., Oct. 17, 2001 , at C1.

164. Enron Form 8-K, supra note $129, \S 2$. 
large enough to bring down Enron, taken alone. The terms of the transactions showed that Enron had been pumping up its earnings by abusing the SPE device. Whenever economics had gotten in the way of a result it wanted, it had used its own high-flying common stock to surmount the sticking point. On the upside this might pass; with the stock falling through the floor this meant trouble. Even worse, Enron no longer had any credibility-no one can believe anything asserted by a firm that covers up losses by entering into sham derivative contracts with itself. ${ }^{165}$

It is possible that the credibility deficit in time could have brought down the firm. ${ }^{166}$ As to that we can only speculate, for independent reasons brought about Enron's collapse before the implications of its SPE accounting could be assimilated fully.

\section{Enron as a Bank Run}

As a part of Skilling's "asset light" strategy, Enron had moved hard assets worth billions into affiliated entities. Many were majority owned by Enron and consolidated into its financials, some of these even having their own credit ratings. Many more were unconsolidated affiliates accounted for under the equity method. We have seen that with its SPEs Enron could divest itself of financial asset, even as it needed to sell only a relatively small stake to outside equity investors. With Enron's unconsolidated affiliates, bigger outside equity stakes were required.

But why would smart money from the financial community commit significant money as Enron divested junk assets? Leverage appears to provide a good working explanation. Enron wanted to realize as much cash as possible from its asset divestments. So in

165. Enron's securities plaintiffs will be putting this earnings management together with stock sales by Enron's officers and directors to depict a classic "pump and dump" operation.

166. More SPE shenanigans have come to light since the Chapter 11 filing. "Braveheart" is the most notorious. Enron transferred its interest in a joint venture with Blockbuster (to use Enron's broadband to sell movies directly to consumer subscribers), which never got off the ground, to an SPE called Braveheart. The SPE bought the right to receive the first ten years of project revenues. A Canadian bank loaned the $\$ 115$ million purchase price to the SPE, with Enron guaranteeing the revenue stream. With Enron bankrupt, the Canadian bank is now left holding the bag. Enron booked a $\$ 110$ million profit on the sale, netting the negative assumed value of the guarantee against the purchase money. The transaction arguably conforms to GAAP. Keller, supra note 97, at A15; Floyd Norris \& Kurt Eichenwald, Fuzzy Rules Of Accounting and Enron, N.Y. TIMES, Jan. 30, 2002, at C1; John R. Emshwiller \& Rebecca Smith, Murky Waters: A Primer on Enron Partnerships, WALL ST. J., Jan. 21, 2002, at C1. 
many cases Enron and its outside equity turned to outside lenders to provide debt capital for the equity affiliate. Had the affiliates borrowed nonrecourse to Enron, these deals would not have threatened Enron's stability.

But it seems that in many cases outside lenders were unwilling to lend on the credit of the junk assets Enron was dumping into its equity affiliates. They insisted that Enron itself be liable on a contingent basis. As an example, the debt of Marlin Water Trust, an affiliate through which another affiliate, Atlantic Water Trust (in which Enron had a one-third equity interest) invested in a company called Azurix Corp., a joint venture that owned a water works in Britain. Marlin was capitalized with $\$ 125$ million in equity and $\$ 915$ million in debt. "Trigger events" in its debt contracts provided that Enron would become liable on its debt if either Enron lost its investment grade credit rating or its common stock price fell below $\$ 59.78$. If either trigger went off, Enron had ninety days to register and sell sufficient common stock to pay down the debt. To the extent Enron did not raise the cash to pay the debt with a stock offering, Enron was obligated to make up the difference in cash. ${ }^{167}$ Similarly, Enron had backed \$2.4 billion of debt of another equity affiliate, Osprey, with a contingent promise to issue Enron equity, and ultimately to assume the debt, should the value of the stock prove inadequate. ${ }^{165}$

The Marlin and Osprey debt obligations show us why Enron's house of cards finally collapsed. As Enron transferred hard assets from its balance sheet into the affiliates, it sought cash consideration for the assets rather than dodgy debt paper issued by the affiliate. Some cash would come in from outside equity participants, but not much. The affiliates had to be levered in order to attract private equity, which would accordingly be putting up only a small fraction of the value of the assets purchased. Significant cash consideration for the assets therefore meant outside lenders. To swing deals in the private placement debt market, Enron gambled on the price of its own highflying stock. If the stock remained buoyant, the obligation to pay the debt came due only on the debt's maturity. At that time, the stillbuoyant stock would provide a painless vehicle for paying off the debt

167. Enron Form 10-Q, filed Nov. 19, 2001, Part I, Item 1.

168. The Marlin/Osprey arrangements were pioneered by Enron together with investment bankers from Citigroup, Credit Suisse, First Boston, and Deutsche Bank. Some then sold similar arrangements to other energy companies, such as El Paso Corporation and the Williams Companies, which also wished to divest junk assets. See Patrick McGeehan, Enron's Deals Were Marketed to Companies by Wall Street, N.Y. TMES, Feb. 14, 2002, at C1. 
should the value of the affiliate's assets fall short. If Enron's stock fell gradually and caused the trigger to go off, Enron could get out from under the debt by minting more stock. It would have a problem on only one scenario. If the triggering stock decline was a free fall, Enron would be unable to bail itself out with a new stock offering and the debt would be accelerated directly against it. It was the last scenario that actually occurred.

Here was high-leverage financing in a mode that the promoters of the leveraged buyouts of the 1980s never would have dared to imagine. The 1980s deals were old economy deals, in which lenders looked to the earning power of hard assets and took mortgages and security interests in the assets. ${ }^{169}$ New economy company that it was, Enron borrowed on a virtual basis: It took on contingent obligations secured in the first instance by its own market capitalization and incurred for the purpose of divesting itself of its own assets. In the 1980s, a highly leveraged deal presupposed a projection that the company would generate earnings before interest and taxes sufficient to cover the debt. At Enron in the virtual 1990s, the value to back the deal came not from such an inside projection of what the firm could earn, but from the market stock price. Stock prices also result from future earnings projections-projections made by outside traders with limited information about the company. Sometimes, in runaway stock markets, the projections are dispensed with entirely as the traders chase trends.

Unfortunately, Enron took this gamble on its own stock price in such a bubble stock market. And so the gamble failed. As we have seen, Enron's stock declined for independent reasons as 2001 unfolded. This, together with the crisis in confidence triggered by the SPE disclosures, caused further price declines. Contract contingencies began to trigger obligations on billions of off-balance sheet debt. And, in a conjuring trick unimaginable to the principals of Drexel Burnham Lambert in their most creative moments, Enron had incurred these contingent liabilities without bothering fully to disclose them in its financial statements, whether on the balance sheet or in the footnotes. Indeed, it delayed public disclosure until the last possible point-midNovember 2001.

169. There is, however, one notable point of commonality. In the more risky $1980 \mathrm{~s}$ deals, the lenders looked less to the hard assets of the borrower than to spreadsheets showing upward growth projections for the borrower's cash flows. Enron, when borrowing against its own common stock, was borrowing on the assumption that financial reality lay behind the heroic growth projections implied by a price earnings ratio of sixty. 
The sudden appearance of $\$ 4$ billion of additional obligations struck Enron with more devastating effect than would have been the case with an old-fashioned, hard assets company. ${ }^{170}$ Enron already was frantically trying to prop itself up with new borrowing, ${ }^{171}$ including a $\$ 1.5$ billion infusion from its partner in a bailout merger, Dynegy. ${ }^{172}$ Dynegy, on hearing of the $\$ 4$ billion, immediately insisted that the $\$ 9$ billion merger price be reduced to $\$ 4.17$ billion. At the same time, analysts reckoned that Enron needed $\$ 4$ billion of immediate cash from somewhere to sustain its trading operation. But no cash was forthcoming. Enron's trading business melted away; in the last weeks almost all of its volume stemmed from unwind orders from parties going elsewhere. Dynegy waited a week after learning of the $\$ 4$ billion, and then called off the deal. This happened just after Standard $\&$ Poors, having concluded that there would be no rescue, downgraded Enron to junk status. ${ }^{173}$ Enron had nowhere to go but the Chapter, where it ended up in a few days' time. It was, as erstwhile CEO Jeff Skilling later observed, a "classic run on the bank."174 No wonder he had bailed out in August. ${ }^{175}$

Skilling's description is apt. Enron had come to look more and more like a financial intermediary, whether a bank or a broker-dealer. Such businesses depend on customer confidence. As we have seen, Enron already was looking less than confidence-inspiring by October 2001. But a financial intermediary's customers do not necessarily care

170. The list of hidden obligations kept growing. The components of the $\$ 4$ billion are broken down in Enron's Form 10-Q, supra note 167, Part I, Item 2. When Standard \& Poor's downgraded Enron's debt to BBB- on November 12, the downgrade by itself triggered $\$ 1.6$ billion of contingent equity affiliate liabilities to due and owing status (including, on a beltand-suspenders basis, some already triggered, like the Marlin borrowings). Standard \& Poors, focusing on Enron's unsuccessful foreign investments, had put Enron on notice of its concerns about the credit rating in June. Enron talked it out of a downgrade. Zellner et al., supra note 3, at 32. The collapse of Enron's stock price triggered an additional \$3.1 billion of obligations, $\$ 700$ million of these in connection with a derivative contract. In addition, one of Enron's principal credit facilities contained a "material adverse change" clause that also was triggered by the downgrade. Oppel, supra note 79, at C3. Jeff Skilling argues that such a clause is unusual in such a contract. Id. In a form similar to that of a merger upset condition, he may be right. But conditions with similar cut-off effects are standard in debt contracts. What is hard to imagine is how a bank could sign a contract that required it to continue lending in the face of a sudden fifty percent increase in the borrower's long-term debt.

171. It had to exit the commercial paper market in November. Enron Form 10-Q, supra note 167, Part I, Item 2.

172. Id.

173. John R. Emshwiller \& Rebecca Smith, Corporate Veil: Behind Enron's Fall, A Culture of Operating Outside Publics View, WALL ST. J., Dec. 5, 2001, at A1.

174. Oppel, supra note 79, at $\mathrm{Cl}$.

175. See Coy et al., supra note 4, for a quote from an unnamed senior Enron employee to the effect that Skilling understood the mess he had created and resigned for that reason. 
about earnings management and executive self-dealing transactions so long as their own contracts are performed to the letter. Here "confidence" in the first instance means creditworthiness signified by an investment grade rating, particularly when the intermediary does business in derivative transactions. (That is why banks do this business through special purpose subsidiaries with independent credit ratings.) To lose the rating is to lose the derivatives business, as counterparties take their business risks to a shop able to enter into derivative contracts entailing no significant default risk.

As with the watered stock and the equity swaps that weren't, a good part of the story of the hidden liabilities was there to be gleaned in Enron's 2000 Annual Report. Although many affiliates and SPEs were unconsolidated, the magnitude of Enron's asset transfer program was apparent. Of the $\$ 23.4$ billion of "Investments and other Assets" reported on its balance sheet, $\$ 5.3$ billion (22.6 percent) represented investments in "unconsolidated equity affiliates."176 Footnote 9 shows that these entities' liabilities exceeded that of Enron-they had a total of $\$ 4.7$ billion current liabilities, $\$ 9.7$ billion long-term debt, and $\$ 6.148$ billion of "other noncurrent liabilities."177 We also see clearly on Enron's income statement that its percentage share of affiliate earnings (accounted for under the equity method) could impact its bottom line significantly. In 1999 , this figure was $\$ 309$ million, $34.6 \%$ of Enron's net earnings of $\$ 893$ million. The figure fell to $\$ 87$ million in $2000,8.8 \%$ of that year's reported $\$ 979$ million of operating net income. ${ }^{178}$

Enron's cash flow statement also presents interesting numbers. ${ }^{179}$ Proceeds from sales of "merchant assets," which in Enron's accounting scheme generate operating earnings, in 2000 generated $\$ 1.8$ billion of cash and $\$ 1.3$ billion of "unrealized" noncash gains. Again there is a

176. ENRON, supra note 36 , at 32 .

177. Id. at 42 .

178. Id. at 31. Disclosures respecting the contributions to Enron net earnings of the proceeds of transfers of financial assets to SPEs are murkier. Enron reports $\$ 541$ million of extraordinary gain on asset dispositions in 1999 (60.6\% of net income of $\$ 893$ million) and $\$ 146$ million of such gain in 2000 ( $14.9 \%$ of net income of $\$ 979$ million). Id. But Enron does not tell us how much of those figures represent sales to SPEs. It does give us reason to suspect that they do represent such sales when both of these figures are backed out of the operating cash flow section of Enron's cash flow statement, signaling a sale of assets for a paper consideration. In 2000 , the trading and derivative operation generated $\$ 1.63$ billion of income before interest and taxes, while "sale of asset" activities generated $\$ 889$ million of such income. Id. at 23 . In the light of hindsight, both numbers, and particularly the latter, would be more meaningful if transactions with SPEs had been broken out separately.

179. Id. at 34. 
signal of a sale for paper rather than money. Enron's statement of investment cash flows also makes interesting reading. Of $\$ 4.3$ billion invested, $\$ 933$ million is "equity investments."

Two paragraphs above all in Enron's 2000 MD\&A stand out in light of hindsight. They disclosed the contingent affiliate liabilities and triggers:

Enron is a party to certain financial contracts which contain provisions for early settlement in the event of a significant market price decline in which Enron's common stock falls below certain levels (prices ranging from $\$ 28.20$ to $\$ 55.00$ per share) or if the credit ratings for Enron's unsecured, senior long-term debt obligations fall below investment grade. The impact of this early settlement could include the issuance of additional shares of Enron common stock.

... Enron's continued investment grade status is critical to the success of its wholesale businesses as well as its ability to maintain adequate liquidity. Enron's management believes it will be able to maintain its credit rating. ${ }^{150}$

The paragraphs omit at least two material facts-that the "financial contracts" are affiliate debt contracts and derivative contracts unconsolidated on Enron's balance sheet and that Enron's contingent liabilities under the "provisions" amount to $\$ 4$ billion, a figure which looms large in comparison to the $\$ 1.7$ billion of short-term debt and $\$ 8.55$ billion of long-term debt booked on Enron's 2000 balance sheet. $^{\text {Is1 }}$ Belated disclosure of the $\$ 4$ billion total in November 2001 was by itself sufficient to bring down the firm. ${ }^{182}$

180. Id. at 27.

181. Id. at 33. A highly diligent reader of the financials might have flipped twentyfive pages further on in the financials to find a half-way disclosure: $A \$ 213$ million entry for "guarantees" added to total debt. A further check of a footnote states an assumption of ten percent probability of liability, implying a total of $\$ 21.3$ million of obligations. Id. at 52 . But this $\$ 20$ million appears to be a separate category relating to letters of credit, discussed in footnote 15 . Id. at 48.

182. When Enron, as Chapter 11 debtor in possession, first met with its creditors it reported a balance sheet debt of $\$ 22$ billion as of November 16 (and total debt of $\$ 39.71$ billion). Mitchell Pacelle et al., Enron Has One-Year Restructuring Target, WALL ST. J., Dec. 13,2001 , at A3. Some of this additional debt appears to have been with respect to a swap that involved payment up front to Enron by the bank counterparty of the notional amount; Enron was to repay that sum over five years. Enron received $\$ 3.9$ billion of such hidden loans from 1992 to 2001. Off-balance sheet accounting apparently accorded with GAAP. Daniel Altman, Enron Had More Than One Way to Disguise Rapid Rise in Debt, N.Y. TMES, Feb. 17,2002 , at 1 . Other hidden debt stems from transfers of natural gas purchase contracts among Enron, an offshore subsidiary, and J.P. Morgan Chase. Sale and purchase contracts would be matched, with Enron getting a prepayment for natural gas under the sale contract but not making a prepayment in connection with the matching purchase contract. When it was netted out, Enron had an intermediate term loan from the bank, which was accounted for 


\section{E. Summary and Analysis}

All four of the preceding stories figure into the final account of Enron's collapse. Had Enron suffered no reverses in its basic business and no crisis of confidence, the contingencies respecting the $\$ 4$ billion of obligations that pushed Enron into Chapter 11 might never have occurred. At the same time, had $\$ 4$ billion of additional obligations not come out of the woodwork after Enron entered into a merger agreement with Dynegy, the merger might have been consummated. We can pare down the account by coupling the crisis of confidence and the hidden $\$ 4$ billion of obligations as primary causes. The coupling works well-both stories involve equity affiliate and SPE transactions incident to Skilling's "asset light" strategy and aggressive earnings management. Both stories also involve heavy use of Enron's common stock as a back-up currency importing stability to an otherwise shaky deal structure.

Viewed with the benefit of hindsight, the equity affiliate and SPE transactions appear foolish, reckless, or fraudulent. There arises a question as to just what the top officers of Enron thought they were doing. Clearly, they pursued much more than the realization of Skilling's promise of higher return on invested capital through divestment of hard assets. Short-term stakes loomed larger. Viewed in the short-term, Enron's asset sales to SPEs generated revenues and gains that helped Enron's net earnings meet market expectations during the interval prior to the realization of earnings from Enron's new investments. ${ }^{183}$ Had the financial assets sold to the SPEs been sold for cash to third parties at arm's length, they still would have been a source of funds. But one suspects that the net earnings impact of arm's length sales would have been much less favorable. It accordingly made perfect sense to put Fastow on both sides of the SPE transfers. His divided loyalty assured a purchase price pitched to Enron's bottom line, even as his limited partnership solved the Chewco problem and stood ready to serve as three percent outside investor. At the same

as a sale. Kurt Eichenwald, Enron Hid Big Loans, Data Indicate, N.Y. TMES, Feb. 27, 2002, at C1; Kurt Eichenwald, Questions Raised on Enron Offshore Gas Trades, N.Y. TMIES, Feb. 19,2002 , at $\mathrm{Cl}$. Enron made a similar arrangement with a Connecticut utility, now an unsecured creditor in its bankruptcy. See Paul Zielbauer \& Michael Brick, Connecticut Feels Fallout From Enron, N.Y. TIMEs, Feb. 22, 2002, at C1.

183. Studies show that when growth stocks report even small earnings shortfalls, the resulting stock price declines are disproportionately large. For a summary of the literature, see Patricia M. Dechow \& Douglas J. Skinner, Earnings Management: Reconciling the Views of Accounting Academics, Practitioners, and Regulators, 14 AccTng. Horizons 235, $245-46(2000)$. 
time, Enron used its equity affiliates as a source of debt capital. This borrowing helped the affiliates yield attractive returns for their outside equity investors (and presumably to provide a source of funds for new investments in the push to expand trading markets). Deflecting highleverage equity investment to the affiliates made perfect sense for Enron because it had to limit direct borrowing in order to maintain the investment-grade credit rating on which its trading business depended.

The equity affiliate strategy hit a snag only with the terms imposed by the outside lenders. They wanted security beyond that afforded by the affiliates' assets. Enron's managers responded with a gamble and borrowed against their own stock price. This reflects a belief in their own business plan. They must have figured that the stock price eventually would become bulletproof once the firm was awash in earnings from broadband and other new initiatives. The same projection figured centrally in the LJM-related SPE derivative strategy. In the interim period before the new investments paid off, the sham equity swaps supported earnings per share. Had its stock price stayed buoyant, Enron might have covered the SPE's losses on the derivative contracts with all eyes remaining averted from the economic substance of the transactions. The decision to stay silent about the magnitude of contingent obligations similarly figured into the gamble. Had the stock price stayed up, the only downside on the borrowing was an incidental dilution of the common stock interest. And had the stock stayed up, the strategy might have worked. Unfortunately, with the stock price falling and Skilling pulling out of the company with no explanation, investors and reporters started to ask questions. ${ }^{184}$

So, what now seems foolish, reckless, or fraudulent, does so only because the gamble failed. Of course, gambling is what high-risk high-return businesses are all about. Rarely, however, do we see managers of large firms stake so much (the whole company and their own liberty) on so little (concealment of off-balance sheet obligations and earnings manipulation).

Thus did Enron's managers cross the line from risk-averse to riskprone behavior. Did they do so rationally? We have seen that they had their reasons. We should add compensation to the list. Like most managers today, Enron's managers received significant compensation in the form of stock options. Option holding dulls the actor's sensitivity to degrees of distress on the downside, and at the same time

184. Watkins Letter, supra note 149 (referring to Raptor deals); see also Kraweic, supra note 51, at 321-22 (describing Robert Citron of Orange County and the voters' acceptance of his risky investment strategies). 
giving the actor an incentive to generate chances for upside gains of high magnitude. Thus directed, a group of managers certainly would be more disposed to high-risk strategies. It should be noted, however, that stock-option-based incentives tend to operate in the long term. To effect a tie between compensation and Enron's managers' obsession with short-term numbers, we need to look to Enron's performancebased bonus scheme. These awards grew as Enron's stock price performed better relative to the market as a whole and as managers met performance criteria in respect of factors like funds flow, return on equity, and earnings per share. ${ }^{185}$ Amounts paid in 2001 based on 2000's numbers were substantial: $\$ 9.6$ million for Lay; $\$ 7.52$ million for Skilling, $\$ 3.925$ million for Jeffrey MacMahon; $\$ 3.036$ million for Fastow; and $\$ 2.3$ million for Kopper. ${ }^{186}$

But option holding and bonus taking do not, taken alone, provide a plausible explanation for the Enron disaster. For one thing, option holding now is ubiquitous among American managers. If option holding explains the behavior of Enron's managers, we accordingly should be seeing their behavior pattern everywhere instead of the present handful of companies beset by scandal. As yet, however, these firms remain outliers. For another thing, the Enron officers gambled with more than other people's money. As they crossed the line to fraud, they staked their personal liberty. One senses such actions to lie outside the box of option pricing.

For an alternative rational expectations explanation of the behavior of Enron's managers, we can turn to the "end period problem." ${ }^{\text {,187 }}$ In this scenario, a ordinarily risk-averse rational actor finds her firm in distress due to business reverses. Bankruptcy being the most negative outcome possible, the actor rationally becomes riskprone, gambling everything in one last play to avoid destruction. Concealment comes with the territory. This explanation would make sense for Enron if either the foregoing story of conventional business reverses turns out to be much more severe than presently known or the

185. Enron Schedule 14A, supra note 138, at 15-16.

186. Kurt Eichenwald, Enron Paid Huge Bonuses in '01; Experts See a Motive for Cheating, N.Y. TMES, Mar. 1, 2002, at Al.

187. See Jennifer H. Arlen \& William J. Carney, Vicarious Liability for Fraud on Securities Markets: Theory and Evidence, 1992 U. ILL. L. REv. 691. Professor RoseAckerman offers an interesting variation on the theme in Susan Rose-Ackerman, Risk-Taking and Ruin: Bankruptcy and Investment Choice, 20 J. LEG. STUD. 277, 304-09 (1991). She shows how otherwise rational managers of 1980 s savings and loans faced federal receivership if they continued conservative investment policies due to the fact that they had to pay market rates to their savers. Accordingly, they gambled all on risky investments. 
allegations of a derivatives-based disaster turn out to be true. On either scenario, Enron's principals stumbled into distress and rationally started manufacturing income and concealing obligations as a way of buying time to turn things around and avert disaster.

If, on the other hand, Enron's business was sound but troubled, we need to tell a longer story. This was a firm where concealment became a way of life long before the start of the end period. ${ }^{188}$ Enron's principals did not just wake up to find themselves in trouble. They created much of the trouble themselves, voluntarily and unnecessarily driving the firm into an end period. They did so in pursuit of projects and returns that their business plan could not support. Arguably, rational, risk-averse actors would have moderated the pace of expansion, reporting negative numbers to the extent necessary to portray the firm's financial condition accurately. To tell a compelling causation story on this scenario, we must look to Enron's organizational culture as well as its principals' economic incentives. ${ }^{189}$

Enron fell because it pursued winning to excess. At Enron, winning was everything and everything became a tournament. Its business plan took unbundling to its logical conclusion, projecting a competitive victory over not only other firms but vertical industrial organization itself. Enron's top managers wanted to be surrounded exclusively by winners. So they made their workplace a tournament without end. They created a space that, unlike the outside world of regulation protecting losers, valued above all winning and the risk taking which necessarily precedes it. Winning also meant stunning earnings numbers: Where the tournament is ongoing, what counts is the most recent score. So important was winning at Enron that it became conflated with value maximization.

Labor economics holds out a formal model of a "superstar" actor. ${ }^{190}$ Inspired by the distribution of returns in show business, this describes situations where the size of personal rewards grows in lockstep with the size of the market and both market size and reward are skewed to the most talented people in the activity. ${ }^{191}$ Applying the

188. The most famous example is the Potemkin Village trading floor Skilling ordered set up in 1998 in order to hoodwink visiting analysts. Jason Leopold, Questioning the Books: Enron Executives Helped to Create Fake Trading Room, WALL ST. J., Feb. 20, 2002, at A4.

189. See Langevoort, Organized IIlusions, supra note 51, at 114-15, 130.

190. For a popular application of this economic theory, see ROBERT H. FRANK \& PHILIP J. COOK, THE WINNER-TAKE-ALL SOCIETY (1995).

191. Shenwin Rosen, The Economics of Superstars, 71 AM. EcON. REv. 845 (1981). For example, where consumers of music prefer to hear the most able artist perform, the producer gets an equilibrium unit price that is proportional to her talent. Because neither the 
description by analogy to firms in a market, for a "superstar firm," small advantages in capability vis-à-vis the firm's competitors result in the firm disproportionately dominating its market. No doubt Enron saw itself in this light-as the Tiger Woods of energy trading. Its problem was that, given ease of entry into energy trading and shrinking margins caused by successful competitors, its superstar status was in serious jeopardy. Energy trading turned out to be structurally unsuited to the continued dominance by a superstar first entrant: In a superstar market, there is imperfect substitution amongst competing producers $;{ }^{192}$ in energy trading, one proprietary trading floor turned out to look like another so far as concerned the customers. To realize Skilling's vision of being the biggest and best in energy, therefore, Enron had to keep going boldly where no one had gone before and open new markets. ${ }^{193}$ This resulted in heroic demands for new capital and problems wiih earnings figures. To keep their victory lap going, Enron's managers invented winning value numbers, crossing the line to fraud.

Enron's managers, with a belief system biased toward winning, lost touch with both hard economic constraints and the rules of the game. Ironically, that disconnection followed readily from their tournament workplace environment. Of course, such a reward system can be accounted for as an incentive and monitoring scheme. ${ }^{194}$ But as

price nor cost of other imputs in the market depends on talent, more able sellers produce more output units. The payoff to the top producer is an increasing and convex function of talent. The price of talent thus is an increasing function of talent, causing the distrubtion of income to be skewed relative to the distribution of ability. Id. at $845-47$; see also Glenn M. MacDonald, The Economics of Rising Stars, 78 AM. ECON. REV. 155 (1988) (extending the model to show a superstar market can allow for the development of young talent).

192. Rosen, supra note 191, at 846. In addition, (1) property rights are assigned to the seller so there are no free-rider problems due to nonexclusion and (2) joint consumption of the product by a mass audience creates a scale economy allowing a small number of producers to service the whole market. Id. at 847.

193. Professor Krawiec's description of the make-up of the rogue trader and the tournament structure of the trading floor provide a useful analogy. Krawiec, supra note 51, at 310-14; see also Langevoort, Selling Hope, supra note 51, at 658-66 (noting that the required performance levels necessary to maintain the professional image can increase over time and push an actor to risk-prone behavior).

194. The text uses the term "tournament structure" loosely. The usage should be distinguished from that of the formal economics of tournaments, which address certain workplace practices. More particularly, the worker exchanges compensation for a promotion opportunity; the employer undertakes to promote a set percentage of the employees based on their rank ordering in the tournament. The tournament results in economies respecting monitoring costs - the employer need only observe the workers' relative performance-even as it incentivizes the employees. See EdWARd P. LAZEAR, Personal ECONOMICS 25-37 (1995). This economic theory has been applied to large law firms. See Marc Galanter \& Thomas Palay, Tournament of LaWyers: The Transformation of the Big LaW Firm 
corporate cultures develop, tournament schemes can do more than encourage strenuous efforts and filter out losers. They tend to produce winners of a certain type. ${ }^{195}$ To be sure, such executives are ambitious, persistent, optimistic, and hard working. But persistence does not always guarantee success. Enron's managers pursued their business plan so persistently that they lost their flexibility. ${ }^{196}$ They continued to open new markets on an accelerated schedule, even though their need to maintain an investment grade credit rating made it impossible to do this and at the same time tell the truth about themselves to the capital markets. Nor is the relentless optimism of the tournament winner always a productive force. The optimistic entrepreneur labors under a cognitive bias, which underweights downside risk and overweights both the probability of upside gain and the entrepreneur's own abilities and contributions. ${ }^{197}$ That cognitive bias is inseparable from shareholder value maximization, for the big scores in the stock market come from firms run by entrepreneurs rather than by conventional managers. On the downside, however, it can lead to errant decision making.

Tournament winners get where they are because they see the world around them in ways that serve their purposes, sacrificing a measure of realism. This limitation on their perception is not necessarily undesirable - it contributes to their success, keeping them focused, flexible, and able to get the job done. ${ }^{198}$ But there can be significant costs when material information fails to register. At Enron, just as dissent was not tolerated, so was bad news systematically filtered out. It comes as no surprise that the most outrageous selfdealing described in the Powers Report occurred when Enron was dismantling a transaction structure and wiping the transactional debris from its table. ${ }^{199}$ Eyes at Enron tended to be averted from such clean-

(1991). The application is controversial. See David B. Wilkins \& G. Mitu Gulati, Reconceiving the Tournament of Lawyers: Tracking, Seeding, and Information Control in the Internal Labor Markets of Elite Firms, 84 VA. L. REV. 1581 (1998) (showing that the law firm tournament differs from the tournament described in the economics in significant ways, while asserting that a tournament metaphor remains useful in understanding law firm practices).

195. Donald C. Langevoort, Enron and the Organizational Psychology of Hypercompetition: An Essay for Larry Mitchell, 70 GEO. WASH L. REv. (forthcoming 2002).

196. Id. at $142-43$.

197. See Langevoort, Organized Illusions, supra note 51, at 139-40; Langevoort, Selling Hope, supra note 51, at 645.

198. Langevoort, supra note 195, at 4.

199. The Southampton grab of Fastow, Kopper and others occurred in connection with the windup up the LJM1 SPE. When Enron repurchased Chewco's interest in JEDI, Kopper 
up exercises. Actors at Enron also underestimated external threats, ${ }^{200}$ particularly regulatory threats. At Enron, success always had depended on averting or destroying regulatory opponents. Skilling, as we have seen, saw nothing wrong with averting his eyes from insubordination within Enron's own ranks-so long as the result had been profitable. Unsurprisingly, tournament winners score highly on the Machiavellian psychological measure. ${ }^{201}$

As Enron's leaders stepped across the line to fraud, their belief system trumped reality. So as to avoid confronting their own failures, they averted their eyes from the manifest implications of their own actions. ${ }^{202}$ They acted out the role of the tournament winner right up to the end.

\section{ENRON AND CORPORATE SELF-REGULATION}

The preceding story supports a highly confident prediction that the federal securities laws' regime of ex post liability will come to bear on Enron's managers with considerable force. It only remains to complete the picture of who knew what and when. Enron's former top managers have shown manifest awareness of this. Skilling professes ignorance: "We're all trying to figure out what happened. ... This was a tragedy. I had no idea the company was in anything but excellent shape." ${ }^{\text {203 }}$ Moreover, "I didn't do anything wrong. . . . I think we made the right decisions." ${ }^{204}$ The Fastow partnerships? These were set up to save Enron money; information about the $\$ 30$ million "stunned" him. ${ }^{205}$ Billions of off-balance sheet debt obligations? "I did not know about that."206 As for Fastow, his lawyer, David Boies, has added two points. First, Enron's chief accounting officer did not report to Fastow. Second, although Fastow was aware of the operations of the SPEs, which his own firm managed, he was not aware of the activities of the

negotiated a $\$ 10$ million return on an initial investment of $\$ 125,000$. POWERS REPORT, supra note 53 , at 8 .

200. This is "cognitive conservatism." Langevoort, Organized Illusions, supranote 51, at 135-37.

201. Langevoort, supra note 195, at 3; see also Samuel Bowles et al., The Determinants of Earnings: A Behavioral Approach, 39 J. ECON LrT. 1137, 1161-62 (2001) (collecting studies showing high convariance of "high mach" scores with income and occupational attainment, particularly in loosely structured sales organizations).

202. See Langevoort, Organized Illusions, supra note 51, at 144-45.

203. Oppel, supra note 79, at C3.

204. Id.

205. Id.

206. Id. 
other SPEs. $^{207}$ Finally, Ken Lay has disavowed any knowledge of the numbers and side deals-they always were, he said, "way over [his] head." ${ }^{203}$ Thus does the defense strategy emerge: Cite the complexity of the contractual arrangements in question, plead ignorance, and point the finger downward in the chain of command.

\section{A. Enron and the Monitoring Model of Corporate Governance}

The Powers Report rightly faults Enron's board for defective ongoing monitoring of the LJM transactions. But like all such reprimands, this one has the benefit of hindsight. And even as it finds fault, the report also shows us that Enron's board went by the book when it approved the LJM transaction structure. Favorable reports lay on the table at the board meeting in question. ${ }^{209}$ Andersen and Enron's outside counsel, Vinson \& Elkins, had been involved every step of the way. Because of the transactions' self-dealing aspect, the Board required ongoing monitoring by managers representing Enron's interest. In addition, the Audit Committee was to review the transactions annually. There also was active concealment of negative information by middle management. This occurred both with the sham transaction concocted to lend Chewco the appearance of an outside equity investor ${ }^{210}$ and with a series of patch-up arrangements concluded after the swaps went sour. ${ }^{211}$ At only one point does the Powers Report account hold out hope for a plaintiff contemplating a duty of care lawsuit against Enron's outside directors. The three committee reviews of the ongoing LJM-related transactions were conducted quickly, lasting no more than 10 or 15 minutes, without probing questions being asked. ${ }^{212}$ Between Smith $v$. Van Gorkom ${ }^{213}$ and the duty of care cases respecting financial institutions, ${ }^{214}$ these facts

207. Floyd Norris, S.E.C. Wants to Question Former Officer, N.Y. TIMES, Dec. 13, 2001 , at C6.

208. Alex Berenson, Chief's Words Paint Hands-Off Image, but Actions Offer Different View, N.Y. TMEs, Jan. 23, 2002, at C7.

209. POWERS REPORT, supra note 53, at 157 .

210. Id. at 46.

211. Id. at $98,115-18$.

212. Id. at 162 .

213. Smith v. Van Gorkom, 488 A.2d 858 (Del. 1985). Enron is an Oregon corporation. Delaware law is referenced as a source of persuasive points respecting the fiduciary duties of officers and directors of publicly traded corporations. Enron appears to have had more than enough in the way of internal compliance controls to excuse the board under the supine standard of In re Caremark International, Inc. Derivative Litigation, 698 A.2d 959 (Del. Ch. 1996).

214. See, e.g., Francis v. United Jersey Bank, 432 A.2d 814, 846-47 (N.J. 1981) (finding breach of duty when directors failed to act to prevent other directors from 
give a plaintiff a basis for argument. But a strong defense can be anticipated-each of Andersen, Vinson \& Elkins, and Enron's managers had reviewed the transactions and continued to endorse them. The audit committee met with the Andersen partners with Enron's managers out of the room to ask if there was anything about which to worry. Andersen kept silent. ${ }^{215}$

Thus do the facts of the case send a strong but disturbing signal: Enron stumbled into its end period while following the book of good governance practice, at least nominally. A question arises: Why did our system of corporate governance, with its monitors and gatekeepers, fail to interpose frictions on the formulation and execution of the strategy so as to cause prudent modifications? Vigilant monitoring might have contained the recklessness, saving the company. As a matter of policy, the finger points not to lower officers, as Skilling and Fastow would have it, but to Enron's outside directors and with them the monitoring model of corporate governance.

The monitoring model holds out an objective, process-based system. It importunes companies to put a majority of highly qualified outside directors on the board and to integrate the board into its decision-making structure as an active participant. At the level of mandate, however, it only requires that boards go through the motions of making considered business judgments respecting corporate transactions. It does not and cannot make the further subjective inquiry into the degree of attention and quality of judgment actually brought to bear. Corporate counsel are well-schooled in packaging documentation so that compliance is well evidenced. The system responds to breakdowns such as Enron's by adding layers of new processes, each a ritualized enactment of the substance of the good governance.

To see how little this can mean in terms of sustained and searching confrontation with problematic topics, consider the audit committee of the board of directors and its central place in the system. This was the venue within Enron for outside monitoring of accounting policies respecting SPE compliance and the place where questions should have been asked about compliance with GAAP respecting SPE transactions and the $2000 \mathrm{MD} \& \mathrm{~A}$ 's failure to provide complete information about Enron's contingent obligations. Audit committee practice became a focal point of corporate governance reform efforts

misappropriated trust funds); Litwin v. Allen, 25 N.Y.S.2d 667, 678 (Sup. Ct. 1940) (noting that directors must "exercise some degree of skill and prudence and diligence").

215. POWERS REPORT, supra note 53, at 161. 
in the late 1990s, after headline audit failures at Cendant and Sunbeam. SEC Chairman Arthur Levitt complained publicly about audit committee independence and composition. The New York Stock Exchange and the National Association of Securities dealers (NASD) responded by tightening their listing standards. ${ }^{216}$ Under the new rules, audit committees had to have the right to hire and fire the auditor; they had to have at least three members, each of whom should be independent and financially literate, with at least one member having accounting or financial expertise. ${ }^{217}$ At around the same time, the SEC's revised proxy disclosure rules respecting audit committees. Starting in 2001, there had to be disclosures about member independence, the report had to state whether the committee recommended that the Board file the audited financials in the firm's $10-\mathrm{K}$ report, and the committee's charter had to be attached as an exhibit. ${ }^{218}$

For a pristine example of compliance with all the foregoing rules, open Enron's 2001 proxy statement. ${ }^{219}$ Its audit committee of five met five times during 2000 with its outside auditors and its inside managers responsible for accounting and internal controls. The committee was chaired by a professor emeritus in accounting from Stanford University. And yet despite the review and the committee's formal recommendation of the audited financials, the audit had failed and with it the committee process.

Two alternative reform palliatives suggest themselves as the next step in the regulation of audits and audit committees. The first originated with Arthur Levitt and follows the example of Delaware special negotiating committees, which hire their own legal and business advisors. ${ }^{220}$ By extension, audit committees should hire their independent auditor to lead and assist them in evaluating internal compliance systems and the accounting treatments applied by the company's managers and auditors. ${ }^{221}$ Such a contrarian voice might have raised difficult questions about Enron's accounting policies

216. Jeffrey Goldfarb, New Panel to Devise Stricter Oversight Proposals for Independent Auditors, 30 Sec. Reg. \& L. Rep. (BNA) 1455, 1455 (Oct. 2, 1998).

217. HERWITZ \& BARRETT, supra note 8 , at 178 .

218. Audit Committee Disclosure, 17 C.F.R. $\$ \$ 228.306,229.306$ (2000).

219. Enron Schedule 14A, supra note 138, at 12-13, 42-44.

220. See, e.g., Weinberger v. UOP, Inc., 457 A.2d 701, 709 (Del. 1983) (suggesting in a cash-out merger an independent negotiating committee with own counsel and investment banker).

221. For a suggestion of this, see Arthur Levitt, The "Numbers Game," Remarks at N.Y.U. Center for Law and Business (Sept. 28, 1998), available at http://www.sec.gov/news/ speech/speecharchive/198/spch220.txt (last visited Mar. 13, 2002). 
respecting SPEs and affiliates. Whether the process of questioning would have led to a different accounting result and full disclosure of SPE arrangements is another question. For one thing, audit committee members do not differ from other board members in their cooperative dispositions. For another thing, given a limited universe of what are now four big accounting firms, each under pressure to approve the same types of deals, one wonders how much lawyerly adversity can be imported into the system.

The second measure comes from present SEC Chairman Harvey Pitt in his first public response to the Enron collapse. Under this measure, companies and auditors are to make a "[c]onscientious identification and assessment ... [of] the three, four, or five most critical accounting principles" to the company's reporting-the principles involving "the most complex, subjective or ambiguous decisions or assessments."222 They should then make a clear presentation to investors of the problems underlying the decision and report the "range of possible effects in differing applications." the insight is that the monitoring process can lose its way under stacks of technical reports. Accordingly, the process mandate needs to confront moments at which the managers and directors make critical judgments and force them to disclose not only the result and its justification but the competing variables and counterfactuals. By implication, had Enron been forced to this higher level of disclosure it would have followed less aggressive accounting policies. Or, alternatively, much of the accounting would have stayed the same, but Enron would have been forced to make additional pro forma disclosures, which would have revealed all the debt or showed how earnings might have been lower if all of the SPEs were consolidated.

What are the chances that Pitt's reform would have led to disclosure of Enron's contingent liabilities? One suspects that many more than five problematic accounting treatments had material effects on this set of financials. Nothing but hindsight appears to assure that either that consolidation policy, the treatment of the swaps, or contingent liabilities be included on a mandated special disclosure list. In addition, like all other variations on the theme of process guarantee, this one easily could deteriorate into an empty governance ritual having little impact either on the quality of attention and discussion at board and committee meetings or on the understanding of investors in

222. Harvey L. Pitt, Editorial, How to Prevent Future Enrons, Wall ST. J., Dec. 11, 2001 , at A18.

223. Id. 
the stock market. So long as ex post review for compliance relies on objective evidence in the form of a thick minute book, a process rule grounded in subjective "conscientiousness" merely importunes.

Significantly, in a follow-up announcement, the SEC has promised to require each firm's MD\&A to disclose critical accounting policies-those "most important to the portrayal of a company's financial condition ... and require management's most difficult, subjective or complex judgments" ${ }^{324}$-without a limiting number. Perhaps an objective mandate will yet emerge here. But a new disclosure mandate will not restore confidence in the system. Enron's managers concealed the information from their published financials for a reason, after all. What is needed is a third party with the authority to impose the rules.

Meanwhile, if reliable boardroom "conscientiousness" is what is needed, the solution is an independently nominated outside director-an outside super monitor. This suggestion figured prominently in policy discussions a decade ago, when it was thought that newly emerging activist investment institutions could find it convenient to pool resources and nominate candidates to the boards of poorly performing, large capitalization firms. ${ }^{225}$ Unfortunately, no super monitors have appeared because the collective action problems, which prevent shareholders from coordinating on and investing in their own board candidates persist despite concentration of holdings in institutional hands. We will not see super monitors absent massive federal intervention to change the structure of board election and proxy solicitation. 226

Enron, then, reminds us that the monitoring model assures us of little. It gives only a circumstantial guarantee of good governance because it only requires evidence of a "conscientious," well-informed

224. See Press Release, Securities and Exchange Commission, SEC to Propose New Corporate Disclosure Rules (Feb. 13, 2002) [hereinafter SEC Press Release, Feb. 13, 2002], available at http://www.sec.gov/news/press/2002-22.txt (last visited Mar. 13, 2002).

225. See Ronald J. Gilson \& Reinier Kraakman, Reinventing the Outside Director: An Agenda for Institutional Investors, 43 STAN. L. REv. 863, 883-88 (1991); Jeffrey N. Gordon, Institutions as Relational Investors: A New Look at Cumulative Voting, 94 ColUM. L. REv. $124,133-42$ (1994).

226. Perhaps the bottom line message of Enron for corporate governance lies on the contrarian side, with those who suggest that excessive reliance has been placed on the monitoring model. In this view, a majority of outside directors is not the sine qua non of good governance, and enhanced presence of top managers would improve boardroom processes. See Donald C. Langevoort, The Human Nature of Corporate Boards: Law, Norms, and the Unintended Consequences of Independence and Accountability, 89 GEO. L.J. 797, 805-15 (2001). Would a few additional top managers on the board have improved governance at Enron? There is no way to tell. But they hardly could have made things worse. 
business judgment. The conscientiousness itself is ill-suited to ex post verification. In the alternative, the substance of the business judgment could be reviewed. But we have avoided such strict scrutiny on the sound theory that ex post review of risk taking would have perverse deterrent effects. In the chasm separating the circumstantial guarantee from such an actual guarantee lie untold billions of lost investment dollars, and not only in respect of Enron. It is a cost of capitalism. ${ }^{227}$

With that vision of billions in lost capital we finally encounter the self-regulatory corporate law scheme's last line of defense, the investors themselves. ${ }^{228}$ When we look at Enron's shareholders, in particular the institutional shareholders (and the market actors analysts who sell them services), we witness a failure as marked as the failure in Enron's boardroom. Institutional actors with significant capital stakes, whether debt or equity, have access to top executives. It is their job to ask questions when company disclosures fail to tell a coherent story. We have seen that in Enron's case a long list of questions needed to be asked. We also have seen that Enron's public disclosures, although presenting an inadequate picture of the company, provided a basis for asking every question that needed to be asked. Two stand out even without the benefit of hindsight: (1) Just how much contingent liability will be triggered if your stock falls? (2) What percentage of net income would disappear if your SPEs had to be consolidated? The questions' formulation did not require an advanced business degree. A

227. For a more detailed discussion of the law reform agenda, see Jeffrey N. Gordon, What Enron Means for the Management and Control of the Modern Business Corporation: Some Initial Reflections, 69 U. CHI. L. REv. 1233 (2002).

228. The same questions can be asked in respect of Enron's debtholders: How could they put $\$ 8$ billion into the company without asking for an explanation about the contingent liabilities alluded to in the MD\&A? So as concerns Enron's largest banks, an agency explanation resonates well: The middle-level bankers in charge of new loans were not about to disrupt relations with a big client. Patrick McGeehan, 2 Early Enron Lenders Didn't See the End Coming, N.Y. TIMES, Jan. 22, 2002, at C1 (quoting Professor Henry Hu). Questions also are arising about conflicts of interest-Enron's lead banks had an incentive to be accommodating in order to keep up the flow of investment banking business from Enron. There results a revival of discussion about the desirability of the Glass Steagall Act.

The foregoing question applies with greater force to the rating agencies, who downgraded Enron only as the house of cards was tumbling. Contingent guarantees are not rocket science. In the wake of the scandal, two agencies have announced plans to speed up their ratings review process. Riva D. Atlas, Enron Spurs Debt Agencies to Consider Some Changes, N.Y. TIMES, Jan. 22, 2002, at C6. For a persuasive argument that the informational quality of ratings has declined in recent years, see Frank Partnoy, The Siskel and Ebert of Financial Markets?: Two Thumbs Down for the Credit Rating Agencies, 77 WASH. U. L.Q. 619 (1999). 
diligent Accounting for Lawyers student who studied Enron's financials with care ought to be up to the task. ${ }^{229}$

But the questions were not asked. Now, the usual villain at this point is the Wall Street analyst. These actors today are dismissed as mouthpieces for their own firms' investment bankers-because negative reports destabilize investment banking relationships, negative reports are more and more rarely given. ${ }^{230}$ Certainly, the analysts provided no early warnings in Enron's case; indeed, many stayed positive even as the collapse went into its late stages. ${ }^{231}$ But the analysts' reputational stock fell to the floor even before Enron's common stock. No experienced institutional investor was relying on them. ${ }^{232}$

One might have expected holders of significant blocks of stock to speak up. Enron had such stockholders. Janus Capital Corp. owned five percent of Enron's outstanding shares in early 2001. In the words of one Janus analyst, Enron epitomized "the opportunistic thinking of the new economy." Janus managers met repeatedly with Enron's management and included the SPEs in their questioning. Apparently, they did not also insist on coherent answers. Although Janus sold off its Enron during the period from March to October 2001, it still netted $\$ 200$ million of losses. "We'll spend a lot of time internally on our experience with Enron," said a Janus manager whose fund still had four percent its assets in Enron in April. ${ }^{233}$ Alliance Premier Growth Fund, in contrast, still had 4.1 percent of its assets in Enron at the end of the third quarter of 2001. One of its managers later called Enron a "faith stock"-one of many firms with a large market capitalization and so many moving parts that "nobody knows how they put it together."

229. A caveat should be noted. As we have seen, Enron's disclosures were carefully written so as to communicate that everything was all right, assuming that Enron had integrity. Even so, the questions should occur to an investor with a significant stake and an everyday dose of skepticism.

230. Enron did investment banking business only with firms whose analysts rated their stock a strong buy. John Schwartz, Man Who Doubted Enron Enjoys New Recognition, N.Y. TIMES, Jan. 21, 2002, at C8.

231. McTague, supra note 77 , at 1771 .

232. A small number of independent firms do research companies, for a fee. As Richard Grant put it at the time, congressional committees were examining analysts in connection with the Enron collapse, the real problem is that investors do not care enough about getting independent and unbiased research to pay the price. Alex Berenson, Washington Wants Wall St. Changes. But How?, N.Y. TMmes, Feb. 28, 2002, at C6.

233. Aaron Lucchetti, When Bad Stocks Happen to Good Mutual Funds: Enron Could Spark New Attention to Accounting, WALL ST. J., Dec. 13, 2001, at C1. 
"Shame on me," says the manager, "for not doing something" about the opaque financials. ${ }^{234}$

Such stories imply that these investment institutions, despite their significant stakes, acted out the archetype of the noise trader, investing on market hyperbole rather than fundamental value. ${ }^{235}$ Such investment behavior is driven by cognitive bias rather than expert monitoring. These investors chase the trend as they build up their stakes. Then, holding significant blocks in a firm with a price earnings ratio of sixty, they appear to have followed what Kahneman and Tversky called the representative heuristic, making predictions by taking a short history or a small set of facts (Enron's success with electricity trading) and expanding it into a broader picture. ${ }^{236}$ On the downside, some seem to have held on even as the handwriting was on the wall, subjectively assessing the situation by reference to their own sunk costs. ${ }^{237}$

The point is neither that agents of investment institutions always invest foolishly nor that such agents never intervene constructively on the financial side. Rather, the point is that there are surprisingly tight constraints on their utility as a governance check. It seems that even substantial institutional block holding, at least at the five percent level, provides no basis for assuming that the tough questions have been asked and addressed. To find a shareholder who takes on the properties of a super monitor, we presumably need a holder of a bigger block-a twenty-five or thirty percent owner with an inside position or inside agents. One hopes that such an actor, very common in the capital structures of firms on the continent of Europe, would have prevented the fatal excesses of Enron's managers. But, then, if Enron teaches us anything, it is to question the reasonableness of reliance on any corporate monitor.

\section{B. Enron, Generally Accepted Accounting Principles, and Auditor Independence}

In addition to being the largest bankruptcy reorganization in American history (as of December 2, 2001), Enron undoubtedly also

234. Id.

235. See Andrei Shliefer \& Lawrence H. Summers, The Noise Trader Approach to Finance, J. ECON. PERSPEC., Spring 1990, at 19, 19-26.

236. Daniel Kahneman \& Amos Tversky, On the Psychology of Prediction, 80 PSYCHOL. REV. 237 (1973).

237. See Daniel Kahneman \& Mark W. Riepe, Aspects of Investor Psychology, J. PORTFOLIO MGT., Summer 1998, at 52. 
was the biggest audit failure. But, as of this writing, it looks as if the liability provisions of federal securities law may never get the chance to work as contemplated in the case. The auditor, Arthur Andersen, was delivered over to federal prosecutors who avoid attempts to prove criminal violations of complex securities law provisions, preferring wire fraud theories communicable in monosyllabic words. Andersen accordingly was pursued not for its audit performance but for the overtime use of paper shredders at its Houston office in October 2001 as Enron's condition became critical. Its punishment already has exceeded all expectations as of the time of Enron's bankruptcy filing. The indictment and conviction of the firm as a whole, ${ }^{238}$ rather than only its Houston office, pushed it toward the edge of collapse as foreign affiliates and audit clients alike promptly deserted it. ${ }^{239}$

Even Enron's securities plaintiffs have distanced themselves from Andersen. Andersen met the plaintiff class at the settlement table in short order. Apparently, it had determined that no significant protection would be forthcoming from either the pleading barrier erected to private accountant's liability under the Private Securities Litigation Reform Act of 1995 or from a line of cases holding that, absent a direct financial interest in the client, an auditor's interest in a reputation for honesty and care makes an allegation of scienter implausible. $^{240}$ Between the egregious nature of the audit breakdown, the documented awareness of questionable accounting at Andersen's headquarters, ${ }^{241}$ the ex post shredding of Enron-related documents, and subsequent termination of the partner in charge, ${ }^{242}$ the plaintiffs had the smoking gun they needed. But to make it work, Andersen had to survive to fund a settlement. The plaintiffs, watching their deep pocket

238. See Kurt Eichenwald, Andersen Charged with Obstruction in Enron Inquiry, N.Y. TIMES, Mar. 15, 2002, at A1.

239. They have been welcomed by Andersen's delighted competitors. See Henny Sender, Andersen's Audit-Client Defections Come at Perfect Time for Its Overstaffed Rivals, Wall ST. J., Apr. 4, 2002, at Cl. Andersen has been forced to lay off thousands of employees. See Cassell Bryan-Low, Andersen to Cut 27\% of U.S. Staff, WALL ST. J., Apr. 9, 2002, at C24.

240. See Section 21(D)(b)(2) of the Securities Exchange Act of $1934 \S 21$ (D)(b)(2), ch. 404, 48 Stat. $\$ 81,900$ (1934). For representative cases, see Melder v. Morris, 27 F.3d 1097, 1103 (5th Cir. 1994); DiLeo v. Ernst \& Young, 901 F.2d 624, 629 (7th Cir. 1990); Retsky Family Ltd. P'ship v. Price Waterhouse LLP, No. 97-C-7694, 1998 U.S. Dist. LEXIS 17459 (N.D. Ill. Oct. 21, 1998).

241. Jonathan Weil, Enron's Auditors Debated Partnership Losses, Wall Sr. J., Apr. 3, 2002 , at $\mathrm{Cl}$.

242. Thaddeus Herrick \& Alaxi Barrionuevo, Were Enron, Andersen Too Tightly Knit?, Wall ST. J., Jan. 21, 2002, at C1. 
shrink with startling rapidity as 2002 unfolded, ${ }^{243}$ expanded their list of defendants, reaching out to secondary actors among Enron's banks, underwriters, and contract counterparties. ${ }^{244}$

Meanwhile, Andersen's partners staked its survival on a restructuring proposed by Paul Volcker, hastily brought aboard so the firm could avail itself of his reputation for business rectitude. Volcker tried to restore probity to Andersen by having it divest itself of all consulting, going forward as the only large accounting firm performing only the audit function. The palliative turned out to be too little, too late. ${ }^{245}$

For present purposes, the more interesting question about Andersen is why, despite the assumption of the securities cases, a firm like Andersen, for which a reputation for probity and care was as necessary as an investment grade credit rating was for Enron, compromise itself in this way? If this reputational interest cannot be relied upon to cause big accounting firms (then five in number, soon to be four) to impose the rules on reporting companies, then significant law reform is required.

\section{The Violations}

Enron's collapse implicates (at least) three important accounting topics: (a) the off-balance sheet treatment of SPEs and equity affiliates, (b) the treatment of contingent obligations, and (c) fair value accounting for derivatives and energy sales contracts.

\section{a. SPEs and Equity Affiliates}

Recall that at the time of its Chapter 11 filing, Enron already had admitted that its financial statements had overstated its earnings due to failure to follow the rules for qualifying SPEs and indefensible, even fraudulent, treatments of SPE transactions. Some of these violations were technical-the failure to meet the three percent requirement with either Chewco or Talon, the LJM1-related SPE. ${ }^{246}$ The more serious violations concerned the sham substance of the LJM-related swap transactions.

243. See, e.g., Robert Frank et al., Andersen Cuts Enron Settlement Offer by Half, WALL ST. J., Mar. 20, 2002, at C1.

244. Complaint, In re Enron Corp. Securities Litigation, C.A. No. H-01-3624 (S.D. Tex. Apr. 8, 2002).

245. See, e.g., Devon Spurgeon \& Cassell Bryan-Low, Can Andersen Partners Keep Their Firm Alive?, WALL ST. J., Mar. 29, 2002, at C1.

246. POWERS REPORT, supra note 53, at 15-16. 
Note that the identification of these violations does not by itself state a policy issue for GAAP. The problem could lie only with the audit. To see the difficulty of the substantive question respecting SPEs, consider the fact that Enron had thousands of additional SPEs and equity affiliates. As to these no violations have been identified. Here is the question: Would the consolidation of Chewco, JEDI, and the LJM-related SPEs have resulted in meaningful financials, or did many more affiliated entity financials need to be consolidated for a meaningful picture of Enron to emerge?

Let us take the SPEs first. Under SFAS No. 140, issued in 2000, transfers of financial assets to SPEs are treated as sales by the transferor firm so long as, among other things, equity interests in the SPE are not returned as consideration for the assets transferred and the SPE gets control of the assets with the right to pledge or exchange them. ${ }^{247}$ All you have to do is have the SPE vehicle meet the outside equity requirement, and for all that appears at this time, Enron did so with respect to the vast majority of its SPEs.

Now let us take up the equity affiliates. These relationships are dealt with under GAAP rules applicable to all parent-subsidiary relationships. These rules are formal; they do not inquire into the substance of control arrangements. Consolidation follows from greater than fifty percent ownership. At fifty percent equity ownership down to twenty percent, accounting is by the equity method, the mode of accounting employed by Enron for its unconsolidated equity affiliates. Under it, there is no consolidation of the investee company. Instead a portion of the income or loss of the investee flows through to the investor's balance sheet. ${ }^{245}$ (We have seen that Enron's income statement showed significant added income under this treatment. ${ }^{249}$ )

Significantly, vocal dissatisfaction with these rules' form over substance approach has been expressed within the accounting profession. For twenty years, the Financial Accounting Standards Board (FASB) has kept open a project inquiring into an alternative approach based on a substantive definition of control. Reporting companies and the big accounting firms, notably including Andersen and Enron, ${ }^{250}$ have vigorously opposed the project, criticizing the

247. FASB, Summary of JFAS No. 140: Accounting for Transfers and Servicing of Financial Assets and Extinguishments of Liabilities (Sept. 2000).

248. Michael Diamiond et al., FnNancial ACCOUNTING: Reporting and ANALYSIS 535-540 (5th ed. 2000).

249. See supra note 115 and accompanying text.

250. Glenn R. Simpson, Power Play: Deals that Took Enron Under Had Many Supporters, WaLL ST. J., Apr. 10, 2002, at A1. 
FASB's draft rules as unworkable. ${ }^{251}$ The opposition has succeeded and nothing has been done. But, in the wake of Enron, the FASB finally has taken the initiative to push for a revision. The revision will address "strawman" situations where, as with the LJM-related SPEs, a second entity is indirectly controlled by a first entity acting through its agents and a disguised transaction structure. The revision also will visit the question of what constitutes economic substance sufficient to justify treatment as an independent entity. ${ }^{252}$ A minimum ten percent outside equity requirement has been mooted. ${ }^{253}$ Finally, the revision will address equity affiliate situations where party owning fifty percent or less of another entity's stock as a practical matter exercises control. ${ }^{254}$ Action by FASB is predicted for the second quarter of $2002 .^{25 s}$

It should be noted that the LJM-related SPEs suffered from an additional infirmity under GAAP. Under SFAS No. 57, contracts between Enron and the LJM-related SPEs were "related party transactions." These include transactions with a counterparty whose policies are sufficiently influenced by the first party so as to prevent one of the parties from fully pursuing its own interests. Given such a tie, special footnote descriptions of the transactions are required, including dollar amount impacts on reported earnings. ${ }^{256}$ From this it follows that Enron should have disclosed the impact on its earnings of transactions with LJM-related SPEs.

A reform suggestion arises from the related party analysis. The financial and regulatory communities have been focusing exclusively on the rules concerning the consolidation of SPE financials. This inquiry is indeed pertinent: Had the SPEs been consolidated, intercompany transactions would have dropped off of both the balance sheet and income statement, with the result that Enron would not have been able to pump up its net earnings with revenues and gains from transactions with SPEs. At the same time, the substantive equivalent of that result could have been achieved through footnote disclosure of

251. Steve Burkholder, Outlook 2002, 34 Sec. Reg. \& L. Rptr. (BNA) 214, 215 (Feb. $4,2002)$.

252. Jenkins Testimony, supra note 119 , at 14-15.

253. Floyd Norris \& Joseph Kahn, Rule Makers Take On Loopholes That Enron Used in Hiding Debt, N.Y. TIMES, Feb. 14, 2002, at A1.

254. Jenkins Testimony, supra note 119, at 14.

255. Burkholder, supra note 251 , at 216.

256. SFAS No. 57, Related Party Disclosures, ffl 2, 24(f) (Mar. 1982); see also Jenkins Testimony, supra note 119, at 16-17. 
the earnings impact of SPE transactions. ${ }^{257}$ Arguably, such disclosure should be required whether or not the SPE is dealing with a related party and without regard to the level of outside equity capitalization. Even with a ten percent test, questions will continue to be asked about the independence of SPEs. Finally, so long as the SPE's debt is nonrecourse to the transferor, a consolidated liabilities statement is not absolutely essential to the fair presentation of the transferor's financial condition.

\section{b. Contingent Obligations}

In our accounting inquiry up to this point, Enron has violated GAAP only so far as concerns accounting matters restated in its disclosures of October and November 2001-the Phantom Equity Investor, the Watered Stock, the Equity Swaps that Weren't, and some related transactions. These are significant violations, to be sure. But as we have seen, they did not necessarily implicate the company's collapse.

Part III's account of Enron's collapse also suggests a significant accounting problem respecting the $\$ 4$ billion of equity affiliate guarantees that came out of the woodwork in November. As to these GAAP has a definite rule. To guarantee your equity affiliate's obligations is to take the disclosure treatment out of the parentsubsidiary or parent-investee context for treatment under the rules on contingent losses. Here the case for disclosure by Enron is clear-cut. Under SFAS No. 5, loss contingencies are divided into three classes: probable, reasonably possible, and remote. Probable losses should be accrued; reasonably possible losses should be disclosed in footnotes with information as to nature and magnitude; remote losses need not be disclosed. There is a separate rule for financial guarantees. Here even if the possibility of loss is remote, there should be footnote disclosure as to nature and amount. ${ }^{258}$ It follows that Enron's financials

257. The SEC is suggesting that such disclosures be made in the MD\&A. Harvey L. Pitt, Written Testimony Concerning Accounting and Investor Protection Issues Raised by Enron and Other Public Companies: Before Senate Committee on Banking, Housing and Urban Affairs 10, available athttp://www.sec.gov/news/testimony/032102tshlp.htm (Mar. 21, 2002) [hereinafter Pitt Testimony]. The Dodd-Corzine Bill would mandate stepped-up disclosure respecting transactions with SPEs in SEC filings and require the SEC to make formal recommendations to the FASB respecting consolidation rules. S. 2004, 107th Cong. $\$ \$ 301,303(2002)$.

258. See SFAS No. 5, Accounting for Contingencies If 5 (Mar. 1975): "The Board concludes that disclosure of [guarantees of indebtedness of others and others that in substance have the same characteristic] shall be continued. The disclosure shall include the nature and amount of the guarantee." Id.; see also FASB Interpretation No. 34, Disclosure of Indirect 
were in violation of GAAP for understating its obligations as guarantor. ${ }^{259}$

A surprisingly strong counterargument may be anticipated. If a loss contingency under a guarantee involved a small number-say $\$ 100$ million or under respecting Enron's case in 2000-an auditor would have room to waive disclosure under GAAP's materiality principle even if disclosure is otherwise required under SFAS No. 5. Accountants take a bright-line approach to materiality. An item impacting pre-tax income less than five percent is clearly immaterial; an item is clearly material only with an impact of ten percent. ${ }^{2(i)}$ Of course $\$ 4$ billion does not on its face pass the five percent test, even for Enron at its zenith. But suppose we take the $\$ 4$ billion contingency at a time when Enron's stock was selling at almost ninety and ask on a prospective basis what the probability is that the guarantees' triggers will go off. If we were to take a highly confident view of Enron's future and assert that there was only a one percent chance of triggers keyed to stock prices below fifty going off, then the $\$ 4$ billion contingency can be discounted by its one percent chance of occurrence to $\$ 40$ million. That figure is sufficiently small to fly in under the five percent radar so long as pre-tax income exceeds $\$ 1.2$ billion. Alternatively, with a ten percent discount rate (as was employed in Enron's financials with respect to an unrelated $\$ 2$ billion of letters of credit and related obligations ${ }^{261}$ ), we get $\$ 400$ million. Given $\$ 100$ billion of revenues there remains a basis for argument, if not a particularly strong one.

An additional materiality argument can be made. The guarantees did not lie under the same contractual umbrella. They extended across a series of unrelated transactions. Aggressive accountants apply the

Guarantees of Indebtedness of Others (Mar. 1981); HERWTTZ \& BARRETT, supra note 8, at 617-20. Note that under SFAS No. 140, a separate recourse obligation against the transferor of an asset to an SPE with respect to reimbursement for losses on the underlying portfolio (as opposed to a derivative arrangement) continues to be treated under SFAS No. 5. That is the transferor makes an ongoing assessment of the amount of the loss in its financials rather than adjusting the obligation to fair value and reporting it in income. ERNST \& YoUNG, supra note 122 , at 29.

259. And therefore were per se misleading for securities law purposes. See Administrative Policy on Financial Statements, Accounting Series Rel. No. 4, 11 Fed. Reg. 10,913 (Sept. 27, 1946), codified in Codification of Financial Reporting Policies $\$ 101$, reprinted in 7 Fed. Sec. L. Rep. (CCH) \72,921 (May 18, 1988).

260. The SEC, in contrast, insists that small misstatements may be material in some circumstances. See Staff Accounting Bulletin No. 99, 64 Fed. Reg. 45, 150 (Aug. 19, 1999).

261. See supra note 181 and accompanying text. 
materiality principle noncumulatively. ${ }^{262}$ That is, they will take a $\$ 500$ million contingent obligation in isolation and make a separate materiality determination. Given separate transactions with sufficiently small numbers per transaction, materiality could be deployed as a magic wand to make $\$ 4$ billion of contingent obligations go away.

The materiality defense should not carry the day for several reasons. First, even though the transactions were separate, the trigger terms shared common properties. Thus the separate treatment appears inappropriate; even though the transactions were separate, the triggers gave them a cumulative material effect. Of course, once we cumulate the transactions we still have to discount the probability of occurrence. Assuming ten percent probability we get $\$ 400$ million, and $\$ 400$ million is not an insignificant figure compared to Enron's stated $\$ 1.2$ billion of earnings for 2000. Second, even without the benefit of hindsight, some of the guarantees' trigger events were more than ten percent probable. Enron's stock price rode up to ninety in a bubble stock market in significant part on broadband projections. By the time the 2000 financials were released, broadband was in trouble and the bubble had burst. Third, the inference arises that the guarantees were concealed for the very reason that they had a material bearing on the credit rating on which Enron's business depended. Finally, the SEC has strongly objected to aggressive applications of the materiality principle by auditors. Among other things, the SEC staff has reminded auditors and registrants that omissions and misstatements should be inspected both individually and in the aggregate to determine whether the financials materially misstate the position and results of the company. $^{263}$

\section{c. Derivatives}

Accusations respecting Enron's trading and derivatives operation made after the Chapter 11 filing suggest more extensive problems concerning Enron's reported earnings. Even if some of these accusations prove to be true, blame will not necessarily devolve on Enron's auditor, Arthur Andersen. The new rules respecting fair value

262. The auditor's work papers should show all immaterial adjustments on one sheet and should include a cumulation. What happens after that is between the partner in charge and the reporting company.

263. Staff Accounting Bulletin No. 99, 64 Fed. Reg. at 45,150; see also Kenneth C. Fang \& Brad Jacobs, Clarifying and Protecting Materiality Standards in Financial Statements: A Review of SEC Staff Accounting Bulletin 99, 55 Bus. LAw. 1039 (2000). 
accounting for derivative transactions ${ }^{264}$ and for Enron's long-term power supply contracts are quite liberal. For example, they permitted Enron to book a present profit based on a projection of power prices ten years in the future. ${ }^{265}$ Soft though the figures may have been, any fault could turn out to lie with the new rules. ${ }^{266}$ Moreover, if Enron's traders were overstating their profits, it is not automatically the auditor's fault. Audits entail spot checks, not exhaustive reconstructions of all transactions.

The atmosphere of suspicion suggests that the new system of fair value accounting for derivatives and energy contracts may be having perverse effects. The 1990 s move to fair value accounting has been viewed as a breakthrough yielding more meaningful financial statements. Mark-to-market treatment came into the system to prevent financial institutions from using off-balance sheet accounting to hide losses in derivatives trading. Now the crisis of confidence triggered by Enron's collapse reveals a dark side. Absent a trading market, fair value estimates are manipulable. And in a world obsessed with this quarter's earnings figures, they are very likely to be manipulated upward. Thus does fair value accounting sacrifice objectivity and verifiability, once the bedrocks of GAAP.

\section{d. Summary}

As to the first class of Enron accounting violation, concerning SPE consolidation, welcome improvements to the rules can be expected. But it nonetheless should be noted that the central problem here lay not with the rules themselves but Enron's failure to follow them. As to the second Enron accounting problem, nondisclosure of contingent liability on SPE and equity affiliate obligations, GAAP does not seem to be in need of repair. Guarantees are supposed to be disclosed fully in footnotes. As to the third problem, movement to fair value accounting needs to be reconsidered.

\section{Incentive Incompatibility at Arthur Andersen}

We already have a case of audit failure here, only its extent remains to ascertained. The question is not whether GAAP was violated, but how a firm with substantial reputational capital staked on

264. SFAS No. 133, Accounting for Derivative Instruments and Hedging Activities (June 1998).

265. See EITF Issue 98-10.

266. Norris \& Eichenwald, supra note 166, at $\mathrm{C1}$. 
avoiding significant audit failures could have rendered a favorable opinion on the subject financials. Why did Andersen's audit team not pick up the sham in the swaps that weren't? Why did they let the watered stock pass? Was there no review of the guaranty contracts? We must await the results of the many investigations for the detailed factual account.

A broad brush explanation can be offered presently, however. We turn to Enron's 2001 proxy statement, which reports $\$ 25$ million of auditor fees and $\$ 27$ million of other consulting fees to Andersen. ${ }^{267}$ The sham in the equity swaps might have seemed like less of sham in light of $\$ 5.7$ million of Andersen consulting billings for advice respecting Chewco and LJM-related transactions. ${ }^{268}$ Enron, in fact, was Andersen's second biggest client, nationwide. In addition, the top Enron officers in charge of accounting matters were former Andersen accountants. Enron hired away Andersen employees on a routine basis. Meanwhile, numerous Andersen auditors and consultants were permanently posted in offices at Enron. In 1993, Andersen experts had designed Enron's internal compliance system. ${ }^{269}$

The inference of capture is overwhelming. To protect the flow of consulting fees and the value of their long-term relationship with Enron, Andersen's auditors permitted actors at Enron to bully them into signing off on dubious financials. Indeed, so cooperative was the Andersen-Enron relationship that no bullying may have been needed. Andersen's auditors simply mimicked the actions of Enron's managers. As residents of the Enron tower, they no doubt began to internalize the firm culture, becoming risk-prone.

Such assimilation of a risk-prone firm culture is absolutely unacceptable in an auditor. As a primary gatekeeper, the auditor's job is not to collaborate but to bring an objective check to the managers' reports. That check should be not only objective but normatively counterbalancing, introducing a conservatism that reins in the riskprone tendencies of firm culture. The check should also correct results distorted by cognitive bias. ${ }^{270}$ With that accomplished, the information goes to the investment community so that it, rather than the firm's managers, can make the best possible risk assessment.

267. Enron Schedule 14A, supra note 138, at 13.

268. POWERS REPORT, supra note 53, at 161.

269. Herrick \& Barrionuevo, supra note 242 , at C1.

270. Cognitive limitations can impair audit quality even if the auditor has not been captured. See Robert A. Prentice, The Case of the Irrational Auditor: A Behavioral Insight into Securities Fraud Litigation, 95 Nw. U. L. REv. 133, 143-63 (2000). 
Professor Coffee offers a model of an effective financial gatekeeper that highlights three requisite elements: The gatekeeper must (1) be needed for a legally mandated certification, the accuracy of which is observable by the protected class; (2) be a repeat player with a significant reputational capital staked on proper performance; and (3) be expecting only a nominal fee from any one client. ${ }^{271}$ As the factors weaken, points of flexibility in the statement and application of the rules make it more and more plausible for an auditor to pass on a questionable treatment. ${ }^{272}$

In theory, the auditor's reputational interest plus a backstop threat of legal liability should import the requisite adverseness to the auditorclient relationship. Until recently, such was the case. In the 1990s, two factors changed. First, as noted above, the liability system was adjusted to make accounting firms less susceptible to liability to private plaintiffs. ${ }^{273}$ Second, Big Five revenues for nonaudit or "management advisory" services grew to fifty percent of total revenues in 2000 , where twenty years earlier they had constituted only thirteen percent of total revenues. ${ }^{274}$ The result for Andersen's relationship with Enron is the third factor in Coffee's model above ceased to obtain.

To get a sense of the degree to which Enron dominated its auditor, step into the shoes of the partners in Andersen's Houston office on January 1, 2001. The maintenance of good will with Enron's managers must have held a permanent top spot on their list of priorities. How likely, then, was it that an auditor would dare get in the way of the plans of giants like Lay, Skilling, and Fastow? Indeed, given millions in Andersen billings respecting the SPE set-ups, for an auditor to question the sham would have been to undercut the positions of Andersen superiors. So close was the relationship between Andersen and Enron that the Coffee model's second factor became compromised-Enron, and not Andersen as a whole, became the primary reputational concern. ${ }^{275}$ Just as Skilling gambled with Enron's

271. John C. Coffee, Jr., The Acquiescent Gatekeeper: Reputational Intermediaries, Auditor Independence, and the Governance of Accounting 9-10 (2001) (Columbia Law School Center for Law and Economic Studies Working Paper No. 191).

272. Id.

273. The Big Five firms also lobbied intensively at the state level to assure the passage of statutes recognizing the limited liability partnership. I am indebted to Matthew Barrett for this point.

274. Coffee, supra note 271 , at 27.

275. The term for this phenomenon is "sub goal pursuit." The leaders of subunits tend toward excess zeal for their units interests at the expense of the larger firm's interests. John C. Coffee, Jr., Beyond the Shut-Eyed Sentry: Toward a Theoretical View of Corporate 
future in order to make his numbers, Andersen's Houston office gambled with the reputation of the partnership as a whole in order to maintain the revenue flow from their profit center. ${ }^{276}$ But it also must be noted that Andersen's central office in Chicago was not a passive participant. Enron's most aggressive treatments, including LJMrelated transactions and MTM practices, were discussed in a meeting between Andersen's Chicago and Houston offices on February 5, 2001. The participants acknowledged problems. But they ratified the status quo, noting that Enron fees could reach $\$ 100$ million a year. ${ }^{277}$

\section{Reform}

The dangers posed to audit quality by the conflict of interest bound up in ancillary consulting arrangements have been widely discussed. The Big Five firms marketed their advisory services very aggressively. They sold tax products having a record of going over the line of legality. ${ }^{278}$ They also marketed SPE arrangements. Significantly, the more aggressive the accounting implicated in the products, the more important it has been that the seller firm also be the auditor. The sales relationship imports a favorable audit. Alternatively, aggressive transactional "products" have been sold by investment bankers complete with opinion letters from Big Five firms opining conformity to GAAP. The letter serves to constrain later objections from an auditor. ${ }^{279}$

Former SEC chair Arthur Levitt made audit quality and auditor independence a primary agenda item in an accounting regulation initiative launched in the late 1990s. He did not achieve what he requested-a per se ban on consulting by auditors. ${ }^{280}$ Influence activity in Washington by the Big Five firms, led by Andersen, prevented that. Instead, amendments to the SEC accounting rules which became

Misconduct and An Effective Legal Response, 63 VA. L. REv. 1099, 1135 (1977). For an application respecting audits, see Prentice, supra note 270, at 184-86.

276. For a discussion addressed to Andersen as a whole, see Ken Brown \& Jonathan Weil, Questioning the Books: How Andersen's Embrace of Consulting Altered the Culture of the Auditing Firm, WALL ST. J., Mar. 12, 2002, at C1.

277. Internal Arthur Andersen Memorandum, from Michael D. Jones to David B. Duncan (Feb. 6, 2001) (on file with author).

278. Janet Novack \& Laura Saunders, The Hustling of $X$ Rated Shelters, FoRBES, Dec. 14,1998 , at 198.

279. "Robert K. Herdman, the SEC's chief account [has] called for a ban on such letters." Floyd Norris, Can Investors Believe Cash Flow Numbers?, N.Y. TIMES, Feb. 15, 2002, at $\mathrm{Cl}$. A29.

280. Arthur Levitt, Editorial, Who Audits the Auditors?, N.Y. TIMES, Jan. 17, 2002, at 
effective in 2001 prohibited subcategories of nonaudit servicesspecifically, information systems design and internal audit services. Additional proxy statement disclosures also were required. ${ }^{281}$ A glance at Enron's 2001 proxy statement shows Enron and Andersen to have been in compliance. ${ }^{282}$

\section{a. Blaming the Rules}

The Big Five's first response to Enron was business as usual. Even with his firm's reputation on the line, Joe Berardino, the managing partner of Arthur Andersen, joined Enron's officers in pointing fingers elsewhere. The real failure, he said, lay in the accounting rules themselves, which after all permit off-balance sheet financing through SPEs. If something went wrong with Enron's financials, then the problem lay with the rules, which ought to be rethought, not with Andersen's audit. Worse, the whole accounting system needs overhauling. Standards get set too slowly. The system's reliance on historical cost rather than fair value is antiquated in a world needing continuous disclosure for "today's 24/7 capital markets." of this turned Enron into a mess:

Enron disclosed reams of information, including an eight-page Management's Discussion \& Analysis and 16 pages of footnotes in its 2000 annual report. Some analysts studied these, sold short and made profits. But other sophisticated analysts and fund managers have said that, although they were confused, they bought and lost money.

We need to fix this problem. We can't long maintain trust in our capital markets with a financial reporting system that delivers volumes of complex information about what happened in the past, but leaves some investors with limited understanding of what's happening at the present and what is likely to occur in the future. ${ }^{234}$

Writing about Enron a few days later, SEC Chairman Harvey Pitt made substantially similar observations: We need, he said, to find "solutions instead of scapegoats." We need current, as opposed to periodic disclosures including trend information; we need evaluative data in addition to historical cost information; and we need faster standard setting within the accounting profession. The SEC, for its

281. HeRwTZ \& BARRETT, supra note 8, at 196-98. The new subcategories joined an existing list of prohibited services.

282. Enron Schedule 14A, supra note 138, at 13. A18.

283. Joe Berardino, Editorial, Enron: $A$ Wake-Up Call, WALL ST. J., Dec. 4, 2001, at

284. Id. 
part, wants to foster a more cooperative environment, in which an auditor could look to the agency as a "hospitable sounding board."28s

Andersen and the other big accounting firms immediately took up Pitt's offer, sending the agency a joint letter amounting to a challenge. To restore confidence, the SEC should supply "immediate guidance" to public companies respecting disclosure of off-balance sheet transactions, over-the-counter derivative contracts, and related party transactions in time to impact MD\&A in 2001 reports. In particular, the SEC should require issuers to provide more details respecting off-balance sheet guarantees, commitments, lease, and debt arrangements which could impact on credit ratings, earnings, cash flow, or stock price. ${ }^{286}$

These reactions from the actors most responsible for the proper operation of the accounting system must be viewed as surprising, at least by anyone who took the time to read Enron's 2000 Annual Report in light of the events of October and November 2001. Few can question that more current value information in financial reports usefully could supplement historical cost figures. But this issue, which has been a focal point of discussion between the accounting profession and business community for some time, only bears on the Enron disaster as a possible exacerbating factor. Enron used fair value accounting to a significant extent. Analysts confused by Enron's MD\&A could have been disabused of inaccurate notions about the firm's financial condition with accurate reports of past transactions.

It is true that openness in the framework of GAAP makes it harder for accounting firms to say no to big clients. But how open is GAAP's framework? Significantly, in the wake of Enron-related stock market reverses of early 2002, commentators began voicing the opposite complaint. The problem with GAAP, they said, is that it presents an exhaustive check-the-box system of rules. The auditors apply the rules mechanically, ignoring the substance of the clients' transactions. ${ }^{287}$ Even Harvey Pitt, distancing himself from his former clients, has chimed in:

Present-day accounting standards are cumbersome and offer far too detailed prescriptive requirements for companies and their accountants

285. Pitt, supra note 222, at A18.

286. Judith Burns \& Michael Schroeder, Accounting Firms Ask SEC for Post-Enron Guide, WaLL ST. J., Jan. 7, 2002 , at A16.

287. Steve Liesman, SEC Accounting Cop's Warning: Playing By Rules May Not Ward Off Fraud Issues, WALL ST. J., Feb. 12, 2002, at C1; Leaders: The Lessons from Enron, ECONOMIIST, Feb. 9, 2002, at 9. 
to follow.... We seek to move toward a principles-based set of accounting standards, where mere compliance with technical prescriptions is neither sufficient nor the objective. ${ }^{288}$

From all of this there arises a question: Wherein lies the problem with GAAP - too many rules, as these commentators assert, or too many standards, as the Big Five asserted?

The answer is that the problem lies in neither place. There can never be a $100 \%$ directive rulebook in accounting anymore than there is in any other regulatory context. Nor can slavish rule application ever be trusted to yield perfect results. There is always a moment of judgment. Accordingly, GAAP, of necessity, mixes rules and standards and always will do so. Meanwhile, if we return to the application of GAAP to the facts of this case in this Article's previous Part, we see that the rules, applied in good faith, were more than adequate to pick up every material event in the story of Enron's collapse. Contrary to the Big Five's assertions, Enron's auditor did not proceed at the mercy of vague or incoherent rules. Contrary to Mr. Pitt's assertions, a move to standards solves nothing. Standards only work when the actor authorized to apply them is ready to take responsibility for a judgment call.

Why, given a world where neither a commendation of rules nor of standards ever solves a regulatory problem, has the Enron audit failure triggered this bizarre rules versus standards debate? The most plausible answers are denial and avoidance. If GAAP is not fundamentally flawed, then the solution to the Enron problem lies on the enforcement side, where we encounter some highly problematic institutional arrangements.

\section{b. Deepening Crisis and Manifest Inadequacy}

The foregoing back-and-forth between the Big Five and Harvey Pitt occurred before the revelation of document shredding in Andersen's Houston office and the spectacle of a stock market going south due to a lack of confidence in financial reports. These developments revealed the manifest inadequacy of a strategy of cozy cooperation between the SEC and the Big Five. Something had to be done. $^{289}$

288. Pitt Testimony, supra note 257 , at 5.

289. The SEC has announced that it will be introducing a series of Enron-related amendments to existing disclosure rules. See SEC Press Release, Feb. 13, 2002, supra note 224. All are welcome. None address the core problem respecting the audit function. 
Pitt made the first move, addressing the accounting profession's toothless internal disciplinary structure. ${ }^{290} \mathrm{He}$ proposed an independent regulatory body, governed by an independent board, to be effectuated only with the cooperation of the Big Five. ${ }^{291}$ Critics pounced immediately, arguing that too many CPAs would be present in the proposed enforcement structure. ${ }^{292}$ And, indeed, Pitt's proposal did not come close to restoring confidence in the wake of Enron. Given a serious capture problem, there is no assurance that a disciplinary structure with bite will suffice to realign misaligned incentives. After all, the reputational stakes remain very substantial in the absence of a strict regime of professional self-regulation. Yet they did not prevent the Enron audit failure.

And so have actors in government and the Big Five been forced to return to Arthur Levitt's agenda. Congress has taken the lead, nothing further of significance having been heard from Mr. Pitt. ${ }^{293}$ Separation between the audit function and consulting can be effected two ways. ${ }^{294}$ The first is a half-way measure under which the auditing firm may not do any consulting for the audit client. Legislation to this effect has been introduced. ${ }^{295}$ In addition, companies are announcing

290. Coffee, supra note 271 , at 51.

291. Schroeder, supra note 11 , at C1. The suggestion originated with Professor Coffee, although in a much more robust formulation. Coffee, supra note 271, at 52.

292. Diana B. Henriques, Policing the Accountants With a Watchdog From the Accounting Business, N.Y. TIMES, Jan. 21, 2002, at A12. The critics claim that the defendants could stall the process until the completion of overlapping litigation and that the absence of subpoena power will disable the enforcers from gathering necessary evidence. To import such power, a statute is needed. See Mike McNamee, Pitt's Accounting Fix Leaves a Lot Broke, Bus. WK., Feb. 4, 2002, at 38, 38-39. For a more plausible regulation scheme for the accounting profession, see Dodd-Corzine, S. 2002, 107th Cong. $\$ \S 101-104$ (2002).

293. At one point Pitt said that no issue should be off the table in Enron's wake, implying no opposition to significant regulation of the accounting profession. David Leonhardt, How Will Washington Read the Signs? The Race Is on For Tougher Regulation of Business, N.Y. TIMEs, Feb. 10, 2002, at MB1. Later he returned to advocacy of the status quo. Pitt Testimony, supra note 257, at 25-27.

294. Lesser governance reforms also have been mooted widely. Under one of these the audit committee would take entire responsibility for auditor selection. This regulation would be welcome. But it would not solve the problem of implied pressure stemming from consulting income: If management dislikes the audit result, it simply channels its consulting business elsewhere. Mandatory rotation of the audit firm would ameliorate this pressure. But the cure would still be partial. In a world with only four large audit firms, all selling the same advice, rotation would not insulate the auditor from pressure to sanction aggressive treatments.

295. See S. 2004, 107th Cong. $\$ 201$ (2002) (prohibiting accounting firms from providing management consulting services); Auditor Independence Act of 2002, S. 1896, 107th Cong. (2002) (prohibiting accounting firms from providing management consulting services); H.R. 3693, 107th Cong. (2002) (directing the SEC by rule to prohibit an accountant also providing noncredit services from being treated as independent); 
new policies of auditor independence. ${ }^{296}$ Either way, there remains a problem. In a limited world of four firms, all selling the same aggressive products, one can still imagine pressure on the auditors to be cooperative. For a return to adversity, a Glass Steagall regime of separation may be necessary. Under this, the big firms would be unbundled and auditing firms would perform only one function.

Sensing movement toward the more drastic solution, each of the big firms announced early in 2002 that it had divested itself or would be divesting itself of consulting operations. ${ }^{297}$ At the same time, the firms announced that they will no longer perform internal audit work for their audit clients. ${ }^{298}$ Additional details were conspicuously lacking, however. Did "divestiture" mean 100\% separation between the auditing firm and the consulting firm? Or, were the firms' announcements designed to deflect attention from legislated separation, importing no commitment to permanent (or even present) separation? The latter quickly proved the case. When Andersen, under the ministrations of Paul Volcker, announced that it really was going to turn itself into an audit-only firm, the other four firms promptly separated themselves. Still acting in concert, they announced that they had no similar intentions. ${ }^{299}$

Meanwhile, further significant movement to fair value accounting should be deferred. If the audit system cannot be relied upon to apply cost-basis accounting under a rule of conservatism, it presumptively is unready to apply the more complex and subjective measures implicated by a fair value system. Conservatism and hard numbers are not the disease here. They are the cure. Further movement to fair value measures can await the restoration of confidence in the audit system. It was, after all, fair value treatment that enabled Enron to cover $\$ 1.1$ billion of losses with swaps that weren't.

Accountability for Accountants Act of 2002 H.R. 3617, 107th Cong. (2002) (withdrawing benefits of PSLRA from auditors who perform nonaudit functions). A6.

296. Companies Mull Separation of Auditing, Consulting, WALL ST. J., Feb. 4, 2002, at

297. Rachel Emma Silverman, Questioning the Books: Deloitte to Separate Consulting Services From Audit Business, WALL ST. J., Feb. 6, 2002, at A8.

298. Id.

299. Michael Schroeder \& Greg Hitt, Questioning the Books: Big Accounting Firms Break Ties With Andersen to Resist Changes, WALL ST. J., Mar. 4, 2002, at A10. 


\section{Audits and Shareholder Value Maximization}

Had Arthur Levitt still been the chair of the SEC, we would have heard a very different set of observations in respect of Enron's collapse than those of Harvey Pitt, described above. ${ }^{300}$ Levitt's warnings respecting the institutional framework and operations of the accounting system covered most of the salient points in the Enron disclosure disaster-the compromise of auditor independence, the tendency of issuers to manage their net earnings so as to meet analyst's growth expectations, and material nondisclosures justified under the percentage-based materiality principle. Most of all, Levitt warned that the entire financial community followed perverse short-term incentives:

I'm challenging corporate management and Wall Street to re-examine our current environment. I believe we need to embrace nothing less than a cultural change. For corporate managers, remember, the integrity of the numbers in the financial reporting system is directly related to the long-term interests of a corporation. While the temptations are great, and the pressures strong, illusions in numbers are only that - ephemeral, and ultimately self-destructive. ${ }^{301}$

The cultural pathology to which Levitt referred is the culture of shareholder value maximization, aggressively pursued. That culture has changed the nature of the auditor-client relationship. In a free market context it is the managers and not auditors who do the valuecreating. The auditors, like the SEC, regulate the free market, and the present environment of value maximization does not easily concede authority to market regulators. In theory, the auditor-client relationship should have a significant adversarial aspect. Management chooses the accounting policies and practices and the auditor conducts a critical review. If management's choices fall outside the accounting profession's substantive parameters, the auditor imposes compliance with GAAP, wielding the threat of an unfavorable opinion. In today's practice context, the threat has become idle.

The accounting profession has drifted into the role of friendly service provider, lured by management bribes characterized as

300. See supra notes 223 and 285 and accompanying text. Ironically, even as Enron was running out of time, Pitt made a peace offer to the accounting profession, taking the occasion to acknowledge with pride his prior representation in private practice of each of the Big Five firms. The terms of this offer went on to inform the incongruous remarks he later made about Enron's collapse. Harvey L. Pitt, Remarks Before the AICPA Governing Council, available at http://www.sec.gov/news/speech/spch516.htm (Oct. 22, 2001).

301. Levitt, supra note 221. 
consultancy fees. When Enron caused everybody to wake up and ask for an enforcer, the accountants at first asked us to hand the regulatory club to someone else. The only entity equipped to pick it up was the government, acting in the guise of exhaustive rulemaker. Thus did the Big Five entreat the SEC to take over the articulation of GAAP, ready to abandon their own profession's historic assumption of responsibility respecting rulemaking. And they requested more than a transfer of the legislative function. They asked for legislation in the form of rules. This is because imposition of a standard implies voluntary analysis and judgment in which imposition of a rule may be ascribed to the rulemaker's will. The request signifies a profession in wretched decline.

Harvey Pitt convened our post-Enron odyssey by announcing a search for "solutions" not "scapegoats." But he offered no solutions. The criminal justice system took over and made Andersen the scapegoat. No doubt the remaining Big Four breathed easier at that point, hoping that the storm will pass them by and that the new legislation will leave their consultive gravy trains on the tracks. Their hopes may be rewarded. But only complete separation of auditing from consultancy can restore them to health as a profession.

\section{CONCLUSION-ENRON AND THE WAY WE LIVE NOW}

Arthur Levitt's reference to the prevailing culture helps us grasp Enron's meaning for the disclosure system, the regulation of the accounting system, and corporate legal theory. There is nothing new about fraudulent financials, even from repeat players with no immediate plans to skip the jurisdiction. The operative motivations are well-known, and Enron conforms to the pattern: The firm becomes risk-prone, whether it stumbles into an end period or drives itself there in a cultural context in which it loses touch with objective controls. Concealment occurs as it buys time until an external cure relieves its distress.

Despite this, there is an aspect of the Enron story shaped by its time and place. Enron and associated actors reenacted these old pathologies on a stage set by the contemporary shareholder value maximization norm. The norm first made the transition from business commentary to business practice in the $1980 \mathrm{~s}$. At the time it still had a sharp edge of critique. In those days, managers did not pursue shareholder value maximization. Instead they behaved in risk-averse ways, seeking to make the company bigger and safer whether or not that meant more for the shareholders. Actors in the capital markets 
imposed the shareholder value norm on unwilling managers through the harsh medicine of the leveraged restructuring and the hostile takeover.

Things changed in the 1990s. Managers internalized the norm, building resumes as shareholder value maximizers. Stock options better aligned their incentives with those of the shareholders. They emerged in the risk-neutral posture counseled by financial economics. They unbundled conglomerates and concentrated on core competencies. They laid off excess workers. They took care to divert free cash flow to their shareholders through open market stock repurchases. They took on the challenge of global markets. And they emerged as winners as they did so. The high leverage thought by observers in the 1980s to be the key that unlocked the shareholder value treasure turned out to be unnecessary. Its disappearance seemed to remove a threat that pursuit of shareholder value could have perverse effects. Many observers in the 1980s warned that high leverage meant underinvestment in long-term projects. In the 1990s, with the leverage strategy abandoned, shareholder value maximizing management went forward with its only apparent costs falling on the firm's disempowered constituents, the employees let go due to relentless cost cutting. But such losers did not matter. Proponents of America's system of corporate governance took a victory lap on the world stage.

As the 1990s progressed, darker colors appeared in the picture. Some began to question whether the fabulous wealth generated through the combination of liberal stock option plans and rising stock prices had its own perverse effects. At the same time, real-world shareholder value maximization came to be acted out in a bubble stock market. The bubble expanded on projections, which, however wild, were built on the same components that imported content to the maximization norm. The norm became a big tent that encompassed both short-term gains in stock prices stemming from the antics of noise traders and the more sober fundamental value maximization precepts of economists, management scientists, and fundamental value investors.

Managers came under pressure to satisfy both shareholder value constituencies. But the greater pressure, of course, came from the short-term maximization voice of the marketplace. As managers struggled to make their numbers, they were assisted by the Big Five accounting firms, who aggressively peddled tax shelter and earnings management ruses, termed "products." Those who saw through the 
smoke and mirrors and suggested regulation, whether in the selfregulatory system, like the FASB, or in government, like Arthur Levitt, were shouted down and subjected to threats by attack-dog congressmen.

It all came to a head with Enron, where pressure to maximize and a culture of winning combined to draw a huge firm into risk-prone decision making. But the story is exceptional in only two respects. First, comes the magnitude of the numbers. Second, comes the giant step Enron's managers took across the line that separates aggressive accounting from securities fraud. Every other critical detail, ${ }^{3,2}$ including aggressive treatments, auditor capture, and the cognitive biases that facilitated the fatal step to fraud, implicates a well-known business pathology and a concomitant and well-worn regulatory discussion.

Meanwhile, three strong lessons emerge from the wreckage. First, Enron collapsed the same way banks routinely collapsed in the days before deposit insurance. It did so because it had largely succeeded in realizing Skilling's vision of becoming a financial institution. Huge financial institutions present special regulatory problems and are subject to special requirements. Enron remained free of such regulation, partly because of the speed of its transition and partly due to its own successful influence activities. Its collapse shows its exemption to have been unjustified. Emerging financial institutions should be brought into the system in the ordinary course.

Second, even as additional regulatory implications devolve largely on the auditor, avoiding the rest of the self-regulatory system, this case controverts the often asserted claim that existing regulatory mandates fail the cost-benefit test. Those who make that claim rely on market forces and the self-interest of inside actors who face market discipline to assure providers of outside capital against the existence of shabby shops. That the firm with the seventh largest market capitalization and also the firm that preached market discipline the most loudly turned out to be the shabbiest of shops with the cooperation of outside directors, outside auditors, and institutional investors, highlights the limits on what self-regulation and market incentives can achieve. Sovereign mandate and punishment remain capitalism's bedrock.

Third, a century and a half ago, conservatives steeped in the classical economic model of Adam Smith voiced suspicions about the

302. To the extent of present public knowledge. 
accumulation of significant assets within corporate organizations. Only when human beings owned property, they said, could individual interest and moral responsibility work together to keep the use of the property consonant with the interests of society as whole. Corporate ownership subverted market control of private economic power and diluted responsibility amongst the members of a group. ${ }^{303}$ We still hear many voices advocating market control. But we hear it in a fundamentally different context in which corporations, rather than individuals, own the producing assets. For that reason, market controls taken alone cannot possibly assure responsible use of economic power. For the same reason, we should treat with utmost skepticism actors who preach market discipline from positions of safety behind the shields of corporate entities. 
*** 